\title{
A BIOLOGICAL STUDY OF FUCUS VESICULOSUS L. AND F. SERRATUS L.
}

\author{
By Margery Knight, D.Sc.
}

From the Department of Botany, University of Liverpool

and Mary Parke, D.Sc.

Botanist at the Plymouth Laboratory

(Text-figs. I-33)

CONTENTS

PAGE

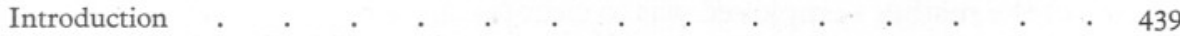

Distribution of the fucoid vegetation . $\quad . \quad$. $\quad . \quad$. $\quad . \quad$. $\quad . \quad$. $\quad$. $44 \mathrm{I}$

Germination . . . . . . . . . . . . . . . . . . . . . . 40443

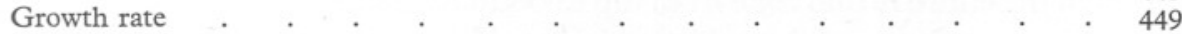

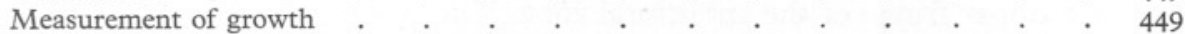

Growth-rate in Fucus vesiculosus . $\quad . \quad$. $\quad . \quad$. $\quad . \quad$. $\quad . \quad$. $\quad$. 450

Growth-rate in Fucus serratus . . . . . . . . . . . . $\quad 451$

Comparison of observed growth-rates with records from other areas . . . . . 453

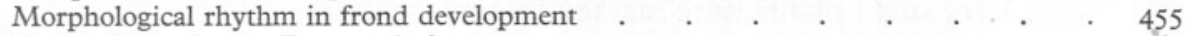

Vesicle-formation in Fucus vesiculosus . . . . . . . . . . . . . . . . 465

Reproduction . . . . . . . . . . . . . . . . . . . . . . 470

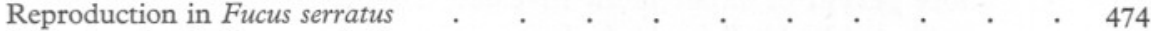

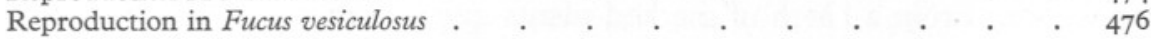

Defoliation . . . . . . . . . . . . . . . . . . . . $48 \mathrm{I}$

Depopulation . . . . . . . . . . . . . . . . . . . $\quad$. 484

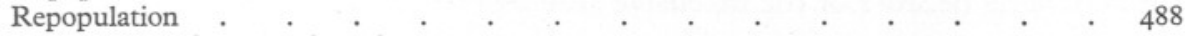

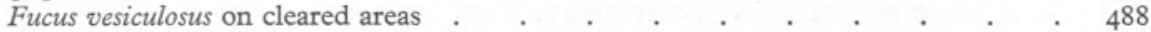

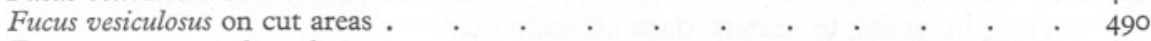

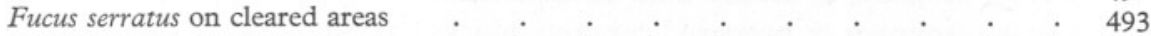

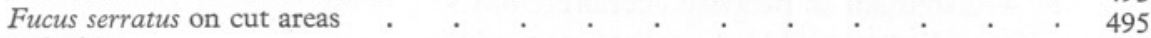

Conclusion

Summary

References

Appendix (Tables IX-XXXIV) .

\section{INTRODUCTION}

Though the two common species of Fucus-F. vesiculosus and $F$. serratusare perhaps the best known of British seaweeds, an investigation into growthrate and longevity for utilitarian purposes has revealed information of a scientific nature which is worthy of record.

Marine algae have provided material for research with varied objectives. The record of it reflects the changing viewpoints common to other branches of botany. The foundation of knowledge of British marine algae was laid by the naturalists of a hundred and fifty years ago, but its value has been overlaid, 
and in some respects obscured, by deflexion into phylogenetics, amplified by detailed inquiry into life cycles, with an emphasis on the light which such study might shed on problems of evolution. Ecological study of marine algae is of comparatively recent growth. Some careful investigation of restricted areas has been made, and modern text-books now tend to assess ecological data as an essential complement to description. Nevertheless, information on behaviour of a plant, and the rhythm of successive growth-phases through which it passes in the course of its life, apart from cytological life cycles, is rarely given.

An investigation has been conducted over a period of five years, with the object of eliciting information on the behaviour of the two fucoid species over a period of time. The methods adopted were those used, with modification in detail, by other algologists (Hariot, I909; Lemoine, I9I3; Nienburg, I930; Hatton, I932).

One of the methods employed was to clear certain areas on the shore, varying in extent from single-metre squares to broad strips $16 \mathrm{~m}$. wide, running through the entire fucoid zone from top to bottom of the shore, and penetrating into the upper fringe of the sublittoral zone. The second method entailed the marking of selected plants in situ. The method of marking which proved most satisfactory was the attachment to the plant of numbered chicken- or hen-rings. Very small plants were marked by small celluloid tablets with a split into which the frond could be inserted.

A very short period of experiment revealed the high mortality-rate among seaweeds. From a batch of marked plants quite often $75 \%$ had disappeared after an interval of only a few weeks. The use of large marked plants was of limited value because of the extensive frond-breakage which occurred, even if the plants were not carried bodily away. Very large numbers of plants had to be marked in order to secure data of statistical significance.

Use was also made of prepared concrete blocks placed on the shore (see Lund, I936). The blocks needed a preliminary soaking in sea water for some time before they could be used with success.

Preliminary inquiry also showed that growth-rate varied with locality, and, to obtain complete data, three stations were selected: south Devon (Wembury, near Plymouth); the south-west corner of the Isle of Man; and a station on the west coast of Argyll. Localities varying in aspect and exposure were chosen on each station to give opportunity of comparing growth-rates under different conditions.

One of the authors (M.K.) is responsible for the data from the Isle of Man, the illustrations, and the compilation of the report. The other (M.P.) has carried out all the observations on the Devon and Scottish stations.

Acknowledgements are due from the authors to the Development Commission, and to the Ministry of Supply, who sponsored the larger investigation from which the facts recorded have emerged. 
Collection of data from the Isle of Man was facilitated by the willing assistance of a large number of students in the University of Liverpool, to whom acknowledgement is due, in particular to Miss Marion Anderton who gave valuable help with the treatment of data. Miss Emily Clay, M.Sc., acted as full-time assistant to Dr Parke.

\section{Distribution OF THE FUCOID Vegetation}

The first point worthy of note which emerged from a comparison of the three areas is that the bathymetric levels of the fucoid zones on the three stations did not coincide.

The restricted area on which observations were made on the Devon coast carried a fucoid vegetation which lay wholly below mid-tide level, whereas a corresponding belt on the Manx and Scottish coasts was much broader and occupied the zone between H.W.N.T. and L.W.S.T.

The findings of the authors for the restricted area at Wembury are not wholly in agreement with the records of Colman (I933) and Evans (I947) for slightly different areas on the same beach.

Colman made four transects on Church Reef at Wembury, three of them radiating from a convenient central point and the fourth set at an angle with one of the other transects. Two of Colman's transects gave a distribution of the fucoid belt quite in keeping with the authors' findings, i.e., except in pools, the fucoid vegetation is confined below or just reaches up to the line of M.S.L. On these two transects, no Pelvetia or Fucus spiralis was present in any quantity.

On the other two transects, the upper limits of the fucoid zone came well above the line of M.S.L. Colman (I933, p. 462, fig. I3) assesses the limits of distribution of the components of the fucoid belt as follows: Pelvetia, from half-way between M.H.W.S.T. and M.H.W.N.T. to the extreme lowest level of H.W.N.T; Fucus spiralis, from M.H.W.N.T. down to I ft. below the extreme lowest H.w.n.T; Ascophyllum, from just below extreme lowest H.W.N.T. to a level half-way between M.L.W.N.T. and M.L.W.S.T; Fucus serratus, from M.S.L. down to L.W.S.T.

Evans (1947, p. I82, fig. 2) included the same area, Church Reef, Wembury, in a general survey of a larger area on the Devon coast with Plymouth as the centre. He claims a higher upper limit for Pelvetia and raises it to a level above E.H.W.S.T. The upper limit for Fucus spiralis is also raised to a level midway between M.H.W.N.T. and M.H.W.S.T. These levels are considerably higher than those found by Colman on his transects, and agree with the authors' findings on the Manx and Scottish coasts. Evans also raises the upper zone of the Ascophyllum belt to M.H.W.N.T. He states that the top of the Laminaria zone is exposed only at the deepest of neap tides on the Devon coast. Evans's survey shows clearly the alteration in level of various algal zones in relation to the 
degree of shelter from wave action, though the alteration is not necessarily in the same direction for all species.

In comparing the zonation of the fucoid belt on areas so widely separated as Devon, the Isle of Man and the coast of Argyll, it is obvious that caution must be exercised in making comparisons when the degree of wave action on each area has not been ascertained. Unfortunately, there is no means of assessing the force of wave action. Nevertheless, the areas selected by the authors in the three stations covered a very wide range of variation in the exposure factor from full surf on a headland facing west to an almost land-locked inlet. On the Manx and Scottish stations, the upper levels of Ascophyllum and Fucus vesiculosus lie higher on the shore than is shown by any of the records for Wembury, or, indeed, for any of the Devon areas surveyed so far. The difference in level amounts to not less than two vertical feet.

The distribution of the fucoid zones on the Manx coast is shown in Fig. I. It can be seen from the figure that Pelvetia lies at or, in sheltered places, above the level of E.H.W.S.T. and that Fucus spiralis reaches the M.H.W.s.T. level. Ascophyllum, accompanied by Fucus vesiculosus, reaches up to midway between M.H.W.N.T. and M.H.W.S.T. The distribution of F. serratus on the Manx coast appears to coincide with that on the Devon coast. Its upper level lies on M.S.L., but its lower limit lies in the fringe of the sublittoral zone. Laminaria digitata also appears to lie higher on the shore on the Manx coast when compared with the Devon coast. From Evans's records it would appear that the upper fringe of the Laminaria zone is exposed only by

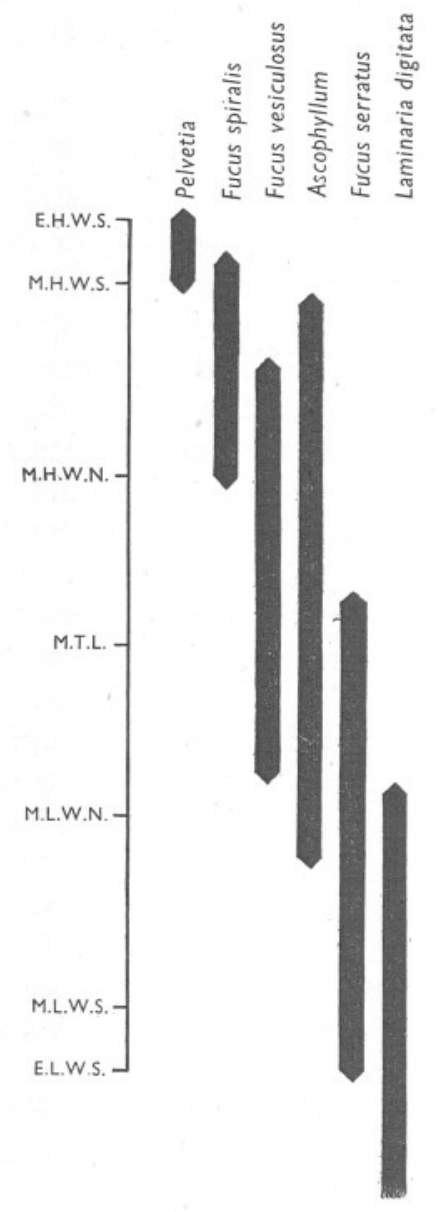

Fig. I. The distribution of fucoids in relation to tidal level at Port Erin, Isle of Man. the deeper low waters of neap tides. On the Manx coast the highest $L$. digitata plants emerge at every low water level.

The relative alteration in level of the fucoid zones on shores of latitudes so far apart as Devon and the Isle of Man is to be expected. Tables for insolation and air humidity and the prevalence of mist or fog show that intertidal exposure on the south coast of Britain is likely to have more severe effects than in the north. The reduction in level of the plants on the south coast by 
shortening the periods of exposure may compensate for the greater danger of desiccation.

\section{Germination}

The periods during which eggs are released from the plants are protracted for both species. Receptacles releasing gametes may be found in varying numbers somewhere or other on the shore for periods of 6 months for Fucus vesiculosus and 8 months for $F$. serratus. Receptacles in various stages of depletion may be found at other times when the egg supply falls to a minimum. The supply of eggs is enormous. Large plants may bear over Iooo fruiting apices, each carrying a large number of conceptacles in which egg development is maintained over a period. The largest number of receptacles recorded on single plants is 4678 for $F$. serratus and 3269 for $F$. vesiculosus. The number of eggs released by such large plants in the course of one fruiting season must be more than a million.

The large number of eggs produced is reflected in the large number of minute plants crowding the substratum below the larger plants. Table I records the number of young plants under $3 \mathrm{~cm}$. in length growing on I-metre-square experimental areas at Wembury. Both the original and final populations after clearance are recorded. The average proportion of young plants under $3 \mathrm{~cm}$. in length, which may be regarded as indicative of the conditions for germination for each square, was $87.1 \%$ for the original and $85.6 \%$ for the final populations on $F$. serratus areas at Wembury. The proportion of such plants on the $F$. vesiculosus areas was somewhat less-74.I \% was recorded for the original and $57.4 \%$ for the final populations.

From these results it would appear that the eggs of $F$. serratus have better opportunity for settlement and germination than those of $F$. vesiculosus. The range of variation in the data for the two species is from 28.2 to $98.9 \%$ for $F$. serratus and from $15 \cdot 2$ to $95 \cdot 2 \%$ for $F$. vesiculosus. The discrepancy between the squares obviously reflects the physical conditions, because the total number of the plants in populations on the squares varies in parallel with the proportion of young plants.

The number of large plants in any area is affected by the degree of exposure of the area to wave action. F. serratus is more sensitive and the proportion of large plants in exposed places falls, thus making the proportion of young plants rise steeply. Conditions for germination may be good, but the rate of depopulation so high that the great majority of the plants may be less than $20 \mathrm{~cm}$. in length. Port Erin Bay, on the Manx coast, faces west, and despite the partial shelter of a ruined breakwater, must be called an exposed coast. Data for the proportion of young plants in the population are given in Table II.

The records from Port Erin show some differences when compared with those from Wembury. The three strips were on a steeply shelving coast and subject to considerable battering by the waves. Metre-squares 8, 9, I9 and 20 
on strip I sloped backwards towards the land and thus gained some shelter from the force of the waves. On these squares alone did the numbers of the

\section{Table I. The Proportion of Young Plants in Populations on I-METRE-SQUARE EXPERIMENTAL AREAS AT WEMBURY}

\begin{tabular}{|c|c|c|c|c|c|c|c|}
\hline \multirow[b]{2}{*}{$\begin{array}{l}\text { Metre } \\
\text { sq. no. }\end{array}$} & \multicolumn{3}{|c|}{ Original population } & \multicolumn{4}{|c|}{ Final population } \\
\hline & $\begin{array}{l}\text { Time of } \\
\text { clearance }\end{array}$ & $\begin{array}{l}\text { Total } \\
\text { no. of } \\
\text { plants }\end{array}$ & $\begin{array}{l}\% \text { under } \\
3 \mathrm{~cm} . \text { in } \\
\text { length }\end{array}$ & $\begin{array}{l}\text { No. of } \\
\text { months of } \\
\text { growth }\end{array}$ & $\begin{array}{l}\text { Total } \\
\text { no. of } \\
\text { plants }\end{array}$ & & $\begin{array}{l}\% \text { under } \\
3 \mathrm{~cm} \text {. in } \\
\text { length }\end{array}$ \\
\hline \multicolumn{8}{|c|}{$F$. serratus } \\
\hline $\mathrm{H} \mathrm{I}$ & $7 \cdot x \cdot 4 I$ & 8,163 & $87 \cdot 9$ & 35 & 5,47 I & & $95 \cdot 4$ \\
\hline 2 & 6. xii. $4 \mathrm{I}$ & 634 & $28 \cdot 2$ & 33 & $\mathrm{I}, 76 \mathrm{I}$ & & $47 \cdot 3$ \\
\hline 3 & I5. vi. 42 & 3,978 & $90 \cdot 5$ & 27 & $\mathrm{I}, 837$ & & $8 I \cdot 0$ \\
\hline$I$ & 6. $x \cdot 4 \mathrm{I}$ & 4,775 & $94^{\circ} \circ$ & 35 & 4,157 & & $95 \cdot 5$ \\
\hline 2 & 4. xii. 4I & 2,205 & $90 \cdot 7$ & 33. & 2,508 & & $9 \mathrm{I} \cdot 7$ \\
\hline 3 & 4. ii. 42 & 1,129 & $87 \cdot 5$ & $3 I$ & 4,855 & & $93 \cdot \mathrm{I}$ \\
\hline 4 & 4. iv. 42 & I,068 & $74 \cdot 9$ & 29 & 4,349 & & $9 \mathrm{I} \cdot 9$ \\
\hline 5 & 23. v. 42 & 7,056 & 93.5 & 28 & 2,271 & & $79 \cdot 2$ \\
\hline 6 & I4. vi. 42 & 4,934 & $97 \cdot 3$ & 27 & 9,373 & & $97 \cdot 3$ \\
\hline 7 & I3. vii. 42 & 2,970 & 97.5 & 26 & 8,022 & & $96 \cdot 7$ \\
\hline 8 & I5. viii. 42 & 2,594 & 93.8 & 25 & 400 & & $60 \cdot 0$ \\
\hline 9 & II. ix. 42 & 7,651 & $95 \cdot 5$ & 24 & $I, 635$ & & $80 \cdot 8$ \\
\hline Io & 9. x. 42 & 1,056 & $72 \cdot 9$ & 23 & I,O34 & & $85 \cdot 7$ \\
\hline I I & 7. xi. 42 & 5,634 & $97 \cdot 9$ & 22 & 3,065 & & $90 \cdot 0$ \\
\hline I 2 & 6. xii. 42 & I,3I9 & $8 \mathrm{I} \cdot 8$ & $2 I$ & I,790 & & $83 \cdot 1$ \\
\hline I3 & 23. i.: 43 & I,OI9 & $95 \cdot 7$ & 20 & 6,863 & & $92 \cdot 6$ \\
\hline I4 & I7. ii. 43 & $I, 004$ & $87 \cdot 6$ & I9 & 9,668 & & 89.0 \\
\hline I5 & 26. iii. 43 & $I, 361$ & $88 \cdot I$ & I8 & I 2,858 & & $9 I \cdot 3$ \\
\hline I6 & 2 I. iv. 43 & 5,664 & $98 \cdot 8$ & 17 & 5,263 & & 84.3 \\
\hline & \multirow{2}{*}{\multicolumn{3}{|c|}{ F. vesiculosus }} & \multicolumn{2}{|c|}{ Total 87,180} & \multirow{2}{*}{\multicolumn{2}{|c|}{ Mean $85^{\circ} 6$}} \\
\hline & & & & & & & \\
\hline I & 5. ii. 42 & 317 & $66 \cdot 6$ & 30 & I I, 589 & & $95 \cdot 2$ \\
\hline 2 & 7. iii. 42 & - & - & 29 & $(6,669)$ & & $(90 \cdot 2)$ \\
\hline 3 & I3. iv. 42 & I,I59 & $69 \cdot 0$ & 29 & I,99I & & $76 \cdot 3$ \\
\hline 4 & I3. v. 42 & 4,786 & $9 \mathrm{I} \cdot 9$ & 28 & 5,720 & & $85 \cdot I$ \\
\hline 5 & I6. vi. 42 & 1,583 & $83 \cdot I$ & 27 & $\mathrm{I}, 574$ & & $74 \cdot 3$ \\
\hline 6 & I4. vii. 42 & I, I53 & $76 \cdot 3$ & 34 & 3,997 & & 80.0 \\
\hline 7 & I3. viii. 42 & I, 827 & $90 \cdot 8$ & 33 & 2,316 & & $92 \cdot 4$ \\
\hline 8 & Io. ix. 42 & 3,837 & $9 I \cdot 2$ & 32 & 646 & & $49 \cdot 5$ \\
\hline 9 & 8. x: 42 & 1,259 & 73.0 & $3 I$ & 345 & & $46 \cdot 4$ \\
\hline Io & 6. xi. 42 & I,698 & $87 \cdot I$ & 30 & 405 & & I9.8 \\
\hline II & 5. xii. 42 & 1,289 & $7 I \cdot 3$ & 29 & 629 & & I9.0 \\
\hline I2 & 20. i. 43 & 1,608 & $72 \cdot 7$ & 28 & I, 4 I 5 & & $48 \cdot 0$ \\
\hline I3 & I8. ii. 43 & 902 & $88 \cdot 7$ & 27 & 699 & & $5 \mathrm{I} \cdot 5$ \\
\hline I4 & 24. iii. 43 & 721 & $44 \cdot 3$ & 26 & 1,365 & & $49 \cdot 3$ \\
\hline I5 & 2o. iv. 43 & $\mathrm{I}, 6 \mathrm{I} 7$ & $64 \cdot 3$ & 25 & $\mathrm{I}, 044$ & & $15 \cdot 2$ \\
\hline 16 & 22. v. $43^{\circ}$ & 1,776 & $40 \cdot 5$ & 24 & $I, I 6 I$ & & $58 \cdot 5$ \\
\hline & Total & 25,532 & Mean $74 \cdot \mathrm{I}$ & $\begin{array}{l}\text { Total } \\
\text { (less sq. } 2 \text { ) }\end{array}$ & 34,896 & Mean & $57 \cdot 4$ \\
\hline
\end{tabular}

F. serratus: I-metre-square areas all re-cleared in September 1944. $\mathrm{H}=$ top of Fucus serratus zone; $\mathrm{L}=$ lower part of the $F$. serratus zone.

F. vesiculosus: Nos. I-5 areas re-cleared August-September 1944. Nos. 6-I6 areas re-cleared April-May 1945.

population approach those for the Wembury area. On the other squares the difficulty in settlement of the eggs is shown by the small numbers of plants in 


\section{Table II. The Proportion of Young Plants in Populations on I-METRE-SQUare EXPERIMENTAL Areas at Port ERIN}

Strip I. Fucus serratus and $F$. vesiculosus

$\begin{array}{ccc}\begin{array}{c}\text { Metre } \\ \text { sq. no. }\end{array} & \begin{array}{c}\text { Total no. } \\ \text { of plants }\end{array} & \begin{array}{c}\text { under ro cm. } \\ \text { in length }\end{array} \\ \text { I } & \text { I24 } & 4 \mathrm{I} \cdot \mathrm{I} \\ 2 & 847 & 94 \cdot 6 \\ 3 & 962 & 93 \cdot 7 \\ 4 & 332 & 70 \cdot 2 \\ 5 & 788 & 92 \cdot 5 \\ 6 & 660 & 48 \cdot 9 \\ 7 & 310 & 98 \cdot 3 \\ 8 & \text { II66 } & 98 \cdot 9 \\ 9 & 2168 & 99 \cdot 2 \\ \text { I0 } & 421 & 93 \cdot 5 \\ \text { II } & 393 & 82 \cdot 9 \\ \text { I2 } & 243 & 83 \cdot 1 \\ \text { I3 } & 597 & 93 \cdot 8 \\ \text { I4 } & 907 & 92 \cdot 1 \\ \text { I5 } & 957 & 88 \cdot 1 \\ \text { I6 } & 876 & 81 \cdot 3 \\ \text { I7 } & 904 & 84 \cdot 2 \\ \text { I8 } & \text { I286 } & 63 \cdot 6 \\ \text { I9 } & 755 & 88 \cdot 1 \\ 20 & \text { II50 } & 87 \cdot 6 \\ 21 & 433 & 79 \cdot 4 \\ 22 & 636 & 92 \cdot 6 \\ 23 & 720 & 87 \cdot 1 \\ 24 & 381 & 82 \cdot 4 \\ 25 & 14 & 21 \cdot 4 \\ 26 & 27 & 88 \cdot 5 \\ 27 & 47 & 29 \cdot 7 \\ & 47 & \end{array}$

Strip 2

Final population

\begin{tabular}{|c|c|c|c|c|c|c|}
\hline & & & & & & \\
\hline & Original & pulation & $F$. ves & ulosus & F. se & ratus \\
\hline $\begin{array}{l}\text { Metre } \\
\text { sq. no. }\end{array}$ & $\begin{array}{l}\text { Total no. } \\
\text { of plants }\end{array}$ & $\begin{array}{l}\% \text { under } \\
\text { Io cm. } \\
\text { in length }\end{array}$ & $\begin{array}{l}\text { Total no. } \\
\text { of plants }\end{array}$ & $\begin{array}{l}\% \text { under } \\
\text { ro cm. } \\
\text { in length }\end{array}$ & $\begin{array}{l}\text { Total no. } \\
\text { of plants }\end{array}$ & $\begin{array}{l}\% \text { under } \\
\text { Io cm. } \\
\text { in length }\end{array}$ \\
\hline II & 68 & $39 \cdot 7$ & 214 & $85 \cdot 5$ & 125 & $46 \cdot 4$ \\
\hline I2 & $\mathrm{I} 2$ & 0 & I88 & $2 I \cdot 2$ & I6I & $90 \cdot \mathrm{I}$ \\
\hline I3 & 3132 & $98 \cdot 8$ & $6 \mathrm{I} 4$ & $84 \cdot 3$ & $48 \mathrm{I}$ & $58 \cdot 2$ \\
\hline I4 & $98 \mathrm{I}$ & $96 \cdot I$ & 214 & 85.5 & 700 & $65 \cdot 8$ \\
\hline I5 & - & - & 2 & 0 & 626 & $75 \cdot \mathrm{I}$ \\
\hline 16 & I637 & $97 \cdot 6$ & - & - & II94 & $62 \cdot 8$ \\
\hline I7 & 46 I5 & $98 \cdot 3$ & 218 & $82 \cdot I$ & III 4 & $60 \cdot I$ \\
\hline
\end{tabular}

Strip 3

\begin{tabular}{|c|c|c|}
\hline \multirow[b]{2}{*}{$\begin{array}{l}\text { Metre } \\
\text { sq. no. }\end{array}$} & \multicolumn{2}{|l|}{$\begin{array}{r}\text { Strip } 3 \\
\text { Fir }\end{array}$} \\
\hline & $\begin{array}{l}\text { Total no. } \\
\text { of plants }\end{array}$ & $\begin{array}{l}\% \text { under ro } \mathrm{cm} . \\
\text { in length }\end{array}$ \\
\hline I3 & I 248 & $3 I \cdot 2$ \\
\hline 14 & 866 & $22 \cdot I$ \\
\hline I5 & I I IO & 10.2 \\
\hline I6 & $\mathrm{I} 2 \mathrm{I} 2$ & $44 \cdot 2$ \\
\hline
\end{tabular}

Note: Strip I. Original clearance August r94I.

Strip 2. Original clearance April I942; re-cleared September I944.

Strip 3. Original clearance August 1942; re-cleared September I 944. 
the populations. The depletion factor is also very high and varies from square to square, so that the range of proportions of plants under $10 \mathrm{~cm}$. in length on the various squares is from $2 \mathrm{I} \cdot 4$ to $99 \cdot 2 \%$.

Strips 2 and 3 were taken across a sharp ridge. Metre-squares $I 3$ and $I 7$ on strip 2 and all four metre-squares on strip 3 lay at a lower angle than the other squares, and the better conditions for settlement are reflected in the larger populations on these squares.

Eggs are sown broadcast over the shore and begin development wherever they fall, even in places where further growth will be impossible. The egg becomes attached to the rock within a few hours of settlement and may adhere firmly enough to the substratum to resist removal by the next returning tide.

An enormous number of eggs are, doubtless, washed away. Many more fall a prey to browsing molluscs, especially limpets and species of Littorina; but, even discounting these risks, there is a sufficient supply of attached eggs to replace plants removed from the population by accident or old age.

Estimation of the time required for the development of a fertilized egg into a visible germling was made by clearing small areas on the shore by a method which ensured the destruction of all eggs and microscopic germlings. This was done by one of three methods: exposing the rock surface, roughly cleared by scraping, to the action of a blow-lamp; by chipping off the surface rock to expose a new surface; by laying down blocks of prepared concrete. After each of these treatments experiment shows that colonization is rapid. From Table III it is seen that the time required for re-establishment of minute plants after all eggs and germlings had been removed does not differ greatly from that required when the surface was merely scraped.

The experimental area on the Manx coast was cleared in August 194I, but there was no opportunity of examining it until December, IOo days later. Consideration of the data provided by the first inspection of the area shows that the time required for germination of the eggs was not dissimilar to that given for the Wembury plants (Tables III, IV, V).

From the foregoing, it may be assumed that growth of the germling is continuous from the time it settles on the substratum, and that it may be visible to the naked eye within 2 weeks of settling.

The experimental areas covered every level at which the two species appear on the shores. There does not appear to be any level which is particularly favourable to settlement of eggs. The differences in settlement in various metre-squares on the areas are not due to difference in level, but they may be due to difference in the texture of the surface of the rock or to the slope of the substratum. Local increase in angle of slope enhances the difficulty in settlement of eggs; a smooth rock surface and absence of cracks is also a deterrent. This is clearly shown by the fact that the earliest and most rapid development of young plants takes place in cracks and fissures in the rock surface. 
Germination of eggs of Fucus serratus is likely to be more uniform at all levels than that of $F$. vesiculosus. The higher level at which the latter species grows exposes the eggs to a greater range of inimical physical factors. Light

\section{Table III. Recolonization of FuCUS SERRATUS AFter Clearance} on the Argyll and Devon CoAsts

\begin{tabular}{|c|c|c|c|}
\hline Experimental area & Method of clearance & $\begin{array}{l}\text { No. of days } \\
\text { after } \\
\text { clearance }\end{array}$ & $\begin{array}{l}\text { Maximum size } \\
\text { of germlings } \\
\text { in } \mathrm{cm} \text {. }\end{array}$ \\
\hline \multicolumn{4}{|l|}{ Argyll: } \\
\hline Serratus Rock & Scraping & $4 \mathrm{I}$ & $I \cdot O$ \\
\hline Ascophyllum Rock, E. strip & Scraping & $4 \mathrm{I}$ & $3 \cdot 0$ \\
\hline \multicolumn{4}{|l|}{ Devon: } \\
\hline Strip sq. 14 & Rock surface removed & 58 & $5 \cdot 2$ \\
\hline Strip sq. I5 & Cleared by blow-lamp & 47 & $I \cdot I$ \\
\hline Strip sq. I9 & Rock surface removed & 38 & $\mathrm{I} \cdot \mathrm{O}$ \\
\hline Strip sq. I9A, 2 & Rock surface removed & I75 & $2 \cdot 0$ \\
\hline F.S.L. I & Scraping & 59 & $2 \cdot 0$ \\
\hline 6 & Scraping & 71 & $4 \cdot 0$ \\
\hline 7 & Scraping & 42 & $3 \cdot 0$ \\
\hline 8 & Scraping & 28 & I. 5 \\
\hline 9 & Scraping & $5^{8}$ & 3.0 \\
\hline Io & Scraping & 64 & $3 \cdot 5$ \\
\hline II & Scraping & 64 & 3.5 \\
\hline 12 & Scraping & 49 & $2 \cdot 0$ \\
\hline I3 & Scraping & 27 & $I \cdot 0$ \\
\hline I4 & Scraping & 31 & $I \cdot O$ \\
\hline 15 & Scraping & 26 & I. 5 \\
\hline I6 & Scraping & 30 & $3 \cdot 0$ \\
\hline
\end{tabular}

Table IV. Recolonization of Fucus serRatus after Clearance at PORT ERIN ON THE MANX COAST

Experimental area

Strip I, metre sq. nos. Io-23

Strip 2, metre sq. nos. 12-15

Strip 3, metre sq. nos. I-2
Method of clearance

Scraping

Scraping

Cleared by blow-lamp

No. of
days after
clearance
IOO \pm 4
IOI
54

Maximum size of germlings in $\mathrm{cm}$.

$\begin{array}{cc}\text { Range } & \text { Mean } \\ 3.0-14.0 & 9.4 \\ 6.0-16.0 & 8.8 \\ 0.5-1.0 & 0.8\end{array}$

\section{Table V. Recolonization of Fucus vesiculosus after Clearance on the Devon and Manx Coasts \\ Experimental area \\ Wembury, metre sq. nos. 5-I6 \\ Port Erin, strip I, metre sq. nos. I-7

\begin{tabular}{|c|c|c|c|}
\hline \multirow{2}{*}{$\begin{array}{l}\text { Method of } \\
\text { clearance }\end{array}$} & \multirow{2}{*}{$\begin{array}{l}\text { No. of } \\
\text { days after } \\
\text { clearance }\end{array}$} & \multicolumn{2}{|c|}{$\begin{array}{l}\text { Maximum size of } \\
\text { germlings in } \mathrm{cm} \text {. }\end{array}$} \\
\hline & & & \\
\hline & $28 \pm I 4$ & $\mathrm{I} \cdot 0-3.0$ & 15 \\
\hline & IOI $\pm \mathrm{I}$ & $3.0-10.5$ & $6 \cdot 0$ \\
\hline
\end{tabular}

favours germination; hence a greater population of small plants in the upper levels of the $F$. vesiculosus zone might be expected. It is a fact that on coasts where the $F$. vesiculosus zone lies high on the shore, as on the Manx coast, the upper edge of the zone carries a dense carpet of young plants, without any larger plants. The factor of desiccation appears to work in contrary direction to 
that of increased illumination, with the result that, though germination may be easy in the upper levels of the belt, further growth is difficult where the periods of exposure are great relative to those of submergence. The result of these two opposing factors on the Manx coast is the maintenance of a dwarf population at the top level of the zone, where the plants remain in a condition of protracted juvenility. An area of plants in this position was kept under observation for 2 years. The plants were $2-3 \mathrm{~cm}$. long and remained at that length for the whole period. That they were still alive was demonstrated by the fact that when the boulder on which the plants were growing was removed to a lower level on the shore in the $F$. vesiculosus zone, the plants began to elongate at once, and within 3 months had reached a length of $9 \mathrm{~cm}$. Their further progress in the new position was quite normal.

On shores sloping towards the south in the Isle of Man, and frequently on the Devon coast near Plymouth, no germlings appear on a cleared area until after a carpet of Enteromorpha or Ulva has developed as a cover to the rock surface. The most vulnerable early stages of germination thus take place under the Enteromorpha carpet, and, by the time the tips of the germlings project above it, they are strong enough to resist desiccation and the depredations of molluscs. Hatton (1932), working at St Vaast-la-Hougue, found the same interaction between Enteromorpha and Fucus germlings. In this more southerly station, Hatton found that a carpet of Enteromorpha was almost an essential condition for good germination of Fucus eggs, and that the latter were noticeably fewer where the Enteromorpha did not develop. Normally, of course, on an uncleared area, the eggs develop under cover of the adult population, which provides adequate protection from desiccation and reduces the risk of destruction by molluscs.

The influence of increased light after clearance of the original population from an area might have been expected to facilitate germination of eggs and lead to a denser population on the experimental areas. This hypothesis has been borne out by experiment. Reference to Table I will show that the final population on the Devon coast was larger than the original population for both species of Fucus. The total original population figures for a series of 16 squares, each I metre square, are: $F$. serratus $64,214, F$. vesiculosus 25,532 ; the numbers in the final populations were: F. serratus 87,180 , an increase of $36 \%$, and $F$. vesiculosus 34,896 , an increase of $37 \%$. The data for the Isle of Man showed an increase of $9.8 \%$ for the final population of $F$. serratus. The figure for $F$. vesiculosus would have been much higher. There was an obvious increase in density of population on the experimental squares, but final analysis was prevented by a storm which covered the experimental area with a pile of boulders.

It is probable that $F$. vesiculosus and $F$. serratus would extend their natural boundaries in the absence of mutual competition. Experiments have shown that areas cleared artificially or accidentally in one zone may be 
colonized by plants proper to another zone. The intruders may persist for a year or longer but will eventually be driven out by competition.

In latitudes more northerly than those investigated by the authors, $F$. serratus may rise higher on the shore and has been found on the upper levels in the Orkney Islands. There are also references to F. serratus at fairly high levels on the south coast of England, but in these circumstances the plants come early into the fruiting stage and die out within a year.

Larger plants are found distributed over the zone at all levels except the extreme upper limits. The best population is found in the middle region where a mixed population of all sizes develops. It is possible that the light factor controls the lower limit of $F$. vesiculosus on the Devon coast, compared with that in higher latitudes. The claim that light is the determining factor was made by Gail (I9I8). The lower position of $F$. serratus relative to that of $F$. vesiculosus may indicate a greater tolerance of reduced light and/or a greater intolerance of exposure to the drying action of the atmosphere.

\section{GrowTH-RATE}

\section{Measurement of Growth}

Two methods were employed to determine growth-rate. The first was to clear an area of its population and then record the sizes of plants in the new population at intervals. Two difficulties immediately became apparent. Eggs from plants in the vicinity of the experimental areas are shed continuously over a long period; later, when the short sterile period approaches, the egg output falls but may not fail completely. The result is that the experimental areas are almost continuously resown with eggs after the experiment has started. The new population on the areas is thus of different ages. Records were made at intervals of the length of the longest plants, on the assumption that the longest would be the oldest in a population of young plants of all sizes, down to just visible germlings. The assumption that the longest plants were the oldest is not necessarily justified because the germlings possess, as is common to seedlings of higher plants, great variation in individual vigour. It is difficult to explain the precocious advance in length of some germlings relative to others on any other grounds. It may be stated, however, that competition may play a part in the early stages of growth, because isolated germlings usually showed higher growth-rate than those which were crowded together; germlings which developed in cracks in the rock also seemed to gain an advantage from their position.

The second difficulty was the very rapid depopulation-rate. Serial records of maximum size sometimes showed a decrease, because the largest germlings had been removed by some agency or another in the interval between the observations.

The other method used was to mark individual plants and to measure 
them at intervals. Here, again, the ease with which plants are broken and the longest fronds removed by rough water or the depredations of molluscs proved a hindrance. This difficulty naturally increased as the plants grew longer.

Increase in length appears to be a uniform process for young plants of both $F$. vesiculosus and $F$. serratus during their first year, irrespective of the time of year at which they start life. This fact was established by clearing metre squares at intervals of I month to cover a whole year. Inspection of older plants suggested that there might be an alternation of periods of vegetative growth and reproductive periods in which extension of the frond was reduced. Serial records of growth through the reproductive period does not, however, bear out this hypothesis. The impression is given by the fact that as the reproductive fronds wear away they leave the new vegetative frondage in full view and very conspicuous by the lighter colour of the frond tips.

Elongation alone is, of course, no full measure of growth. Dichotomy of the fronds and development of lateral frondage goes on simultaneously with linear extension. An attempt was made in some of the experiments to record the degree of 'bushiness' by counting the number of frond apices at the times when their length was recorded. In this feature plants showed individual variation, some developing dichotomies in lateral frondage more vigorously than others. An example of the degree of branching is given in Table IX in the Appendix (p. 50I). Plant $\mathrm{A}_{4}$ showed an increase in the number of frond apices from 16 to 1777 in a period of 377 days, during which it increased in length from $2 \mathrm{I} \cdot 0$ to $6 \mathrm{I} \cdot 0 \mathrm{~cm}$. This plant was evidently a very vigorous specimen because the increase in length in one year was $39.0 \mathrm{~cm}$. compared with the normal yearly extension of $22.4 \mathrm{~cm}$. It was impossible to count the frond apices on all the experimental plants, and as normal extension of frond branching was concomitant with extension, the elongation factor was used as a criterion for growth.

\section{Growth-rate in Fucus vesiculosus}

Observations on frond extension were made in all three areas using the methods of cleared areas and marked plants (Tables IX-XVII, pp. 50I-4).

The experiments in the Isle of Man (Table XV) were brought to a premature conclusion by the incidence of a heavy gale in April 1943, during which the experimental strip was buried under piles of large stones to a depth of several feet and many of the boulders under observation were removed bodily. Data from the Isle of Man, therefore, refer only to a period of I year and 9 months. From the data it has been determined that an average growth-rate of $0.45 \mathrm{~cm}$. per week is maintained by $F$. vesiculosus.

Growth-rate data from Wembury are obtained from a large number of plots selected from all levels and under varying conditions of exposure in the $F$. vesiculosus zone (Tables IX-XIV). A summary of the results from Wembury 
is contained in Table VI. The variation in growth-rate from the individual plots is from 0.25 to $0.7 \mathrm{I} \mathrm{cm}$. per week. The average rate from twenty-eight separate plots is $0.48 \mathrm{~cm}$. per week. This figure agrees reasonably well with the average growth-rate of $0.45 \mathrm{~cm}$. per week for the Manx plants, bearing in mind that the Devon plants had a longer period in which to grow. It has been established that the growth-rate in the second year and succeeding years may be slightly higher than that for the first year.

\section{Table VI. Rate of Growth in Length in Fucus Vesiculosus on the Experimental Areas on the Devon Coast}

\begin{tabular}{lccccc} 
Experimental area & $\begin{array}{c}\text { No. of } \\
\text { sites }\end{array}$ & & Min. & Max. & Mean \\
\cline { 4 - 6 } F. vesiculosus area & 6 & 0.25 & 0.63 & 0.42 \\
Strip, sqs. I4 and I6a & 6 & 0.43 & 0.71 & 0.55 \\
F. vesiculosus metre sqs. & $\mathrm{r} 6$ & 0.32 & 0.57 & 0.47
\end{tabular}

Average growth-rate on 28 sites, $0.48 \mathrm{~cm}$. per week.

The rate of elongation of the Scottish plants showed considerable variation (Tables XVI, XVII). The range of exposure on the individual plots in the Scottish station was very wide and the records show the effect on the growthrate. On the very exposed plot on Sgeir Bhuidhe the rate of elongation for $F$. vesiculosus was, on the average, $0.31 \mathrm{~cm}$. per week, a value which is less than that for growth-rate of $F$. vesiculosus on the Manx and Devon coasts. On the other hand, growth-rates for the other plots on the Scottish station showed much higher values. The Ascophyllum Rock plot which was in a sheltered locality gave a growth-rate of $0.68 \mathrm{~cm}$. per week, a value which is much higher than the average for $F$. vesiculosus on any other station.

Breakage on exposed coasts is higher than in sheltered localities, and the recorded interim lengths may well be less than the real lengths, but a sufficient number of plants escaped breakage to establish the principle that the rate of growth in exposed places is actually slower than in sheltered localities.

\section{Growth-rate in Fucus serratus}

Comparison of the data from the three stations showed considerable variation in growth-rate. On the Devon coast a large number of marked plants were studied, as well as cleared areas. The data from these experiments are given in Tables XVIII-XXVII in the Appendix (pp. 505-10). Summarizing the data from the Devon coast, it may be stated that the average elongation rate for $F$. serratus from all sources was $0.49 \mathrm{~cm}$. per week with a range of variation of $0.3 \mathrm{I}-0.7 \mathrm{I} \mathrm{cm}$. per week. The value $0.49 \mathrm{~cm}$. per week is very close to that found in the same area for $F$. vesiculosus, but the range is slightly more restricted than for the latter species, viz. 0.48 , range $0.25-0.71 \mathrm{~cm}$.

Three areas were examined on the Manx coast. Three strips were cleared in Port Erin Bay. Strip I ran down on a fairly steep coast from H.W.N.T. to 
E.L.W.S.T., passing through the entire fucoid zone. Squares I0-27 ran through the $F$. serratus zone. Table XXVIII in the Appendix gives the details of observations on this strip. The elongation-rate is slightly reduced in the extreme upper and lower levels, but is fairly uniform throughout the greater part of the strip. The average growth-rate is $0.57 \mathrm{~cm}$. per week, with a range of $0.43-0.65 \mathrm{~cm}$. per week. The period of the experiment was 2 years and 9 months. Two other shorter strips alongside strip I gave average rates of 0.58 and $0.68 \mathrm{~cm}$. per week, with ranges of $0.53-0.63$ and $0.65-0.70 \mathrm{~cm}$. per week respectively.

The other two Manx areas lay on the south-east coast at Port St Mary and Castletown (Table XXIX). The growth-rates from these two areas gave rather higher values than those from the Port Erin area. Average values of 0.73 (Port St Mary) and 0.84 (Castletown) $\mathrm{cm}$. per week were obtained.

This variation in growth-rate appears to be correlated with the degree of shelter from direct wave action on the three areas. Port Erin Bay with a steeper coast, facing west, experiences considerable battering by the waves, driven by prevailing westerly winds. Port St Mary and Castletown lie on that part of the coast where the tide runs parallel with the land. The coast is also formed of very gently inclined terraces of limestone, and the waves tend to roll over the shore rather than impinge with battering force against it. The breakage factor on the Port Erin shore is likely to be greater than on either of the other two Manx stations, and it is probable that the observed average elongation-rate here falls rather further below the real elongation-rate than on the sheltered areas. There is, however, other evidence that the growth-rate on the protected areas is really greater than that on the exposed shore at Port Erin. Not only is the maximum length of plants normally greater in the sheltered areas, but the internodes between forkings are also longer. It must be admitted that the records from the two stations on the sheltered coast were drawn from observations over a period of I year only, but comparison of normal populations from the three areas supports the view that growth-rate rises with increasing shelter.

It must be pointed out that the lowest growth-rate recorded for the Isle of Man, even on the exposed coast, exceeds that for the Devon plants and suggests that a higher latitude with reduced inimical factors operating during periods of exposure may also have a beneficial effect on growth-rate.

This hypothesis is borne out by the fact that the highest growth-rates for F. serratus come from the Argyll coast (Tables XXX, XXXI). The various plots on the Scottish coast give a range of elongation-rates from 0.56 to $0.91 \mathrm{~cm}$. per week for three stations, but the range of variation for plots and marked plants within each area is from O.I5 to $\mathrm{I} \cdot 82 \mathrm{~cm}$. per week. The Serratus Rock station was specially chosen because of the luxuriant growth of $F$. serratus in the original population. The average growth-rate on this station was $0.90 \mathrm{~cm}$. per week for cleared areas and $0.91 \mathrm{~cm}$. per week for marked plants. This 
gives a rate for the Scottish plants which is nearly double that of the Devon plants. The greater growth-rate is also accompanied by greater internode length.

A summary of recorded growth-rates for $F$. serratus from all sources is given in Table VII.

Table VII. Rate of Growth in Length in Fucus SeRratus on the Experimental Areas on the Devon, Manx and Argyll coasts

\begin{tabular}{|c|c|c|c|c|}
\hline \multirow[b]{2}{*}{ Experimental area } & \multirow{2}{*}{$\begin{array}{c}\text { No. of } \\
\text { sites }\end{array}$} & \multicolumn{3}{|c|}{ Growth-rate per week $(\mathrm{cm}$.) } \\
\hline & & Min. & Max. & Mean \\
\hline Devo & & & & \\
\hline $\begin{array}{l}\text { Strip, sqs. I5-22 } \\
F \text {, serratus metre sqs. }\end{array}$ & I9 & $\begin{array}{l}0.3 \mathrm{I} \\
0.4 \mathrm{I}\end{array}$ & $\begin{array}{l}0.71 \\
0.63\end{array}$ & $\begin{array}{l}0.48 \\
0.53\end{array}$ \\
\hline
\end{tabular}

Average growth-rate for 38 sites, $0.49 \mathrm{~cm}$. per week.

$\begin{array}{lrlll}\text { Isle of Man: } & & & & \\ \text { Port Erin, strips I-3 } & 26 & 0.43 & 0.70 & 0.59 \\ \text { Port St Mary } & 5 & 0.58 & 0.90 & 0.73 \\ \text { Castletown } & 5 & 0.74 & 1.04 & 0.84\end{array}$

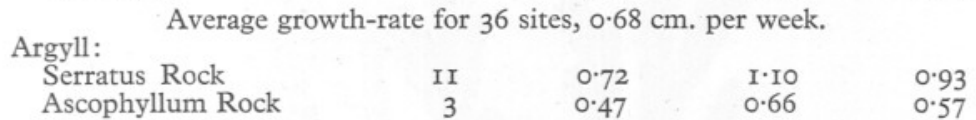

Average growth-rate for $\mathrm{I}_{4}$ sites, $0.85 \mathrm{~cm}$. per week.

\section{COMPaRISON OF OBSERVED GROWTH-RATES WITH RECORDS FROM OTHER AREAS}

A very wide range of growth-rate is given for $F$. vesiculosus and $F$. serratus from other areas. On the French coast, Lemoine (I9I3) records from Roscoff a growth-rate for $F$. vesiculosus of $2 \cdot 5-3 \cdot 3 \mathrm{~cm}$. per month. The period of experiment was short, but if the rate had been maintained over a longer period it would have given a slightly higher rate than that found for $F$. vesiculosus on British coasts. The same is true for $F$. serratus. Lemoine records an increase in length of $\mathrm{I} 2 \mathrm{~cm}$. in 2 months, which is a much higher growth-rate than is shown on British coasts. Records from other French stations show slower rates. Hatton (1932) records elongation-rates from St Servan of 9.8-I3.3 cm. in 7 months. This would give a weekly elongation of $0.3 \mathrm{I}-0.47 \mathrm{~cm}$., a rate comparable with those of British plants. Hariot (I909) records growth-rates of $4.5 \mathrm{~cm}$. in 8 months for $F$. vesiculosus and F. spiralis from St Vaast-la-Hougue. This rate is low and may possibly be attributable to peculiar factors of the environment.

Results from other areas show slower growth-rates. Nienburg (1930) reports an average length of $20-25 \mathrm{~cm}$. per year for both species. Furthermore, Lund (1936) quotes growth-rates of $4-6 \mathrm{~cm}$. per year for the Danish coast and illustrates a plant which measured only $\mathrm{I} 4 \mathrm{~cm}$. at the end of 3 years. Records from the Norwegian coast at Trøndelagen (Printz, 1926) give growth-rates of 
4-7 cm. per year, but Gislén (1930) records for the Gullmar Fjord on the Swedish coast a growth-rate of 6-I4 cm. in 7 months. In extreme northern waters the effect of reduced light has to be considered, as little growth takes place in the dark winters.

The effect of changing salinity may also have an effect on growth-rate. It certainly affects the form of the plant, usually by causing dilatation of the receptacles, and may also affect growth-rate. Colman quotes the work of Segerstråle from Finland in water with a salinity of $4 \%$ and a very small tidal range, in which the author records plants of $F$. vesiculosus which reached a length of $2-3 \mathrm{~m}$. Such a great length has not been equalled by any of the plants which came under observation in the course of the present survey,

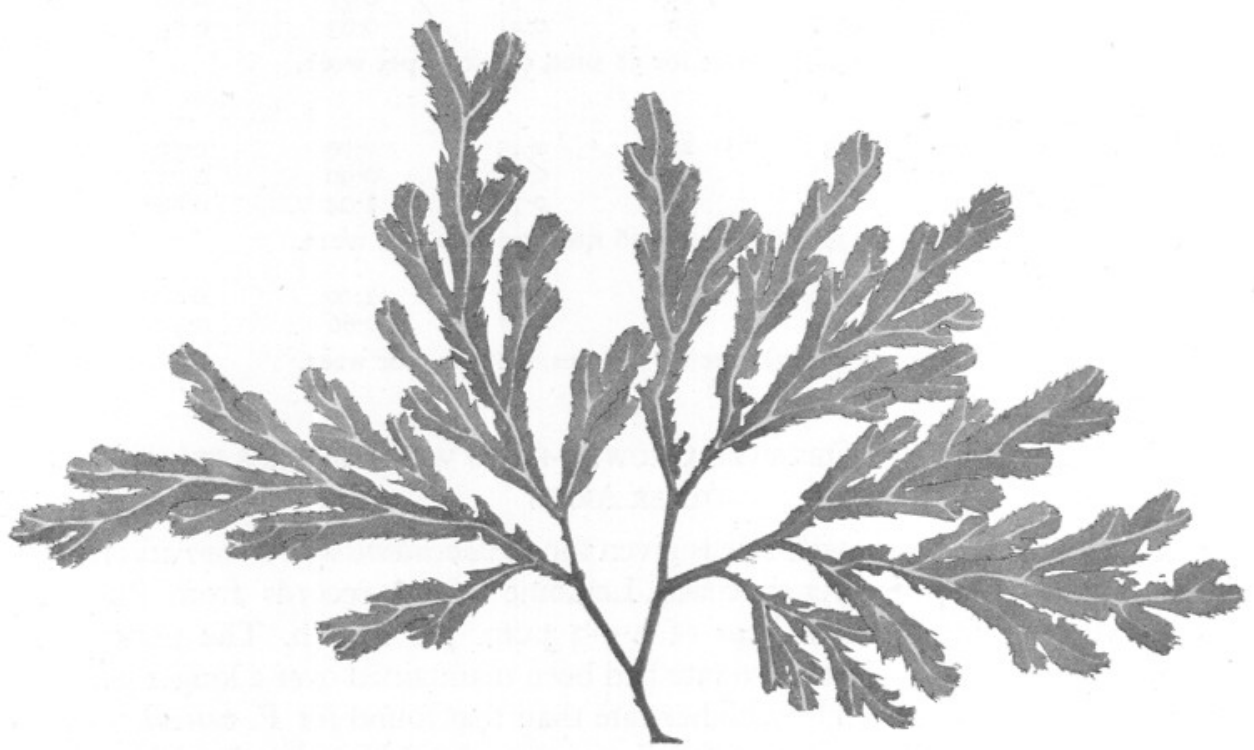

Fig. 2. Sterile plant of Fucus serratus from the Devon coast just over I year old. $\times 0 \cdot 22$.

though old plants of $F$. vesiculosus, consisting of twisted defoliated strands of more than I $\mathrm{m}$. in length, are frequently met with in sheltered places.

Rees (1932) is of the opinion that aeration of the water plays a determining part in the development of both $F$. vesiculosus and $F$. serratus. He reports that at Lough Ine, on the south-west coast of Ireland, F. serratus occurs only in the almost land-locked lough at stations where the tidal current moves with its greatest rapidity.

The greatest contrast in growth-rate found by the authors is between plants of $F$. serratus at Wembury and on the Argyll coast. Fig. 2 shows a plant of $F$. serratus from the Devon station in its second year. This should be compared with Fig. 3, which represents a plant from the Argyll station in its first year. 


\section{Morphological Rhythm IN Frond Development}

Dichotomy of the frond takes place repeatedly, thus dividing it into sections which may be called, for convenience, 'internodes'. In a young plant the first internode is commonly longer than those which follow. On a growing frond the youngest internodes are naturally shorter than in the older ones, but even

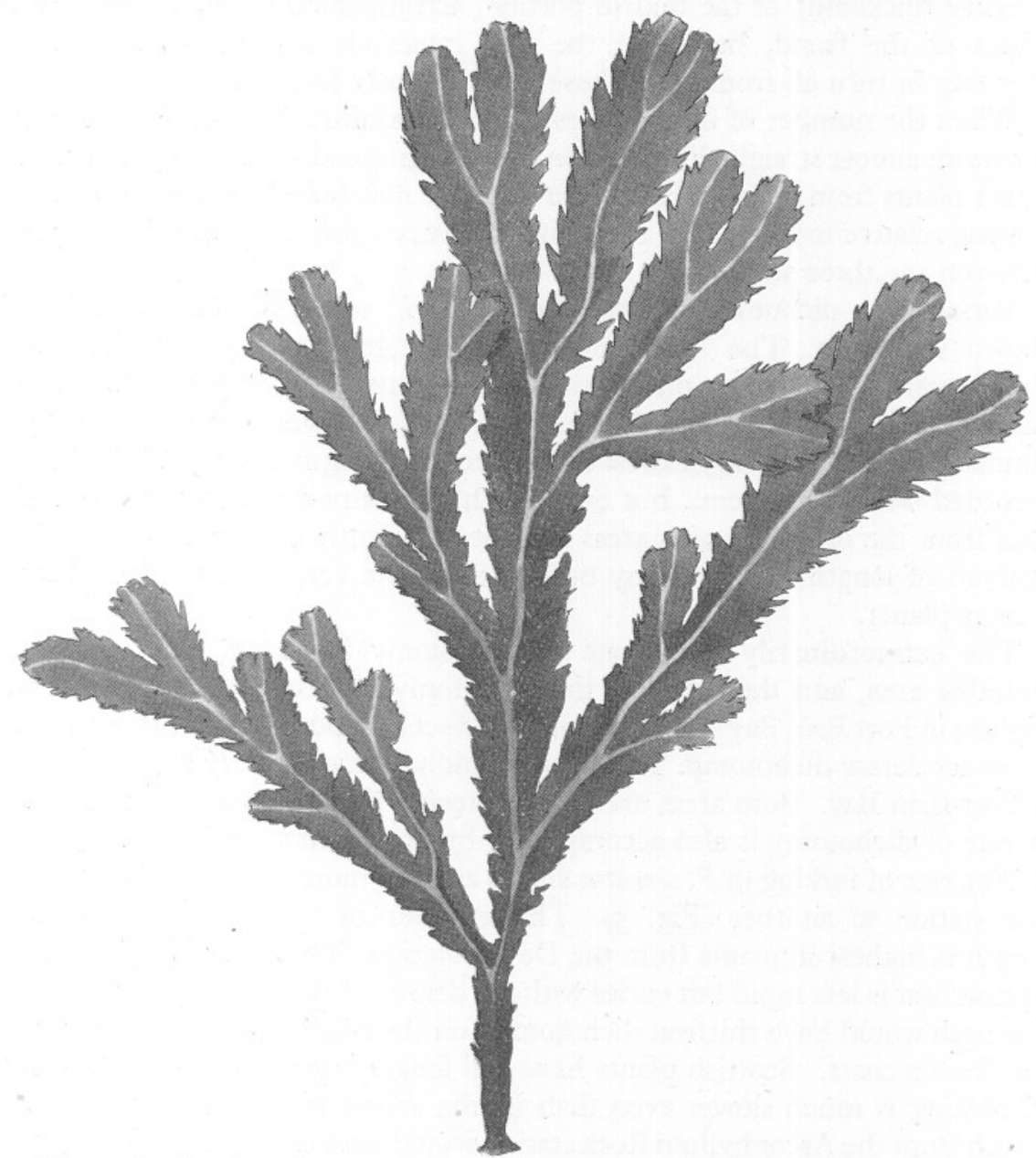

Fig. 3. Sterile plant of Fucus serratus from the Argyll coast in its first year. $\times 0.25$.

mature lengths of internodes vary considerably. The variation in internode length is not so marked in the first year, but as the plant approaches reproduction, those fans that are destined to bear receptacles are forked at short intervals.

When an internode is delimited by apical dichotomy, it may have reached only $40-50 \%$ of its final length. Subsequent elongation is brought about by 
secondary tissue-formation and by swelling of internal cell-walls. The secondary extension diminishes in rate with the passage of time and finally ceases. As a plant grows larger, the basal internodes thicken to form a stipe. The thickening is accompanied by a secondary shortening of internodal length, which may amount to I $8 \%$ of the original (maximum) length. Progressive thickening of the midrib portion, accompanied by denudation of the wings of the frond, begins at the first internode and moves acropetally, affecting in turn all fronds but those most recently formed.

When the number of dichotomies is plotted against frond-length the result shows an almost straight-line relation, but the graph loses form somewhat with larger plants from which much of the frondage may have been lost. The rate of forking relative to length has been found to vary considerably for both species between the three stations.

Variation in dichotomy/length relation for $F$. vesiculosus on all stations is shown in Fig. 4. The Manx plants show a greater rate of forking than the Devon plants. Manx plants would have fourteen and Devon plants nine dichotomies for a length of $60 \mathrm{~cm}$. Plants of $F$. vesiculosus from the Sgeir Bhuidhe area on the Argyll coast did not reach a length of $60 \mathrm{~cm}$. The longest recorded was only $40 \mathrm{~cm}$., but even so, had twenty-three dichotomies. The data from the other Scottish areas are not sufficiently numerous to permit of analysis of length to dichotomy but appear to lie very near to those for the Devon plants.

The extraordinarily rapid rate of dichotomy in plants from the Sgeir Bhuidhe area, and the fact that the dichotomy rate on the Manx coast was highest in Port Erin Bay suggests that one effect of exposure to rough water may be to accelerate dichotomy. The Sgeir Bhuidhe station is very exposed and so is Port Erin Bay. Both areas are also on steeply shelving coasts. The increase in rate of dichotomy is also accompanied by decreased growth-rate.

The rate of forking in F. serratus shows an even more marked variation from one station to another (Fig. 5). The number of dichotomies relative to length is highest in plants from the Devon station. The rate of forking on the Manx coast is less rapid but varies with the degree of shelter. A plant of $60 \mathrm{~cm}$. in length would have thirteen dichotomies on the Manx coast and nineteen on the Devon coast. Scottish plants have still longer internodes, that is, the rate of forking is much slower even than in the Manx plants. Plants $60 \mathrm{~cm}$. in length from the Ascophyllum Rock station would have only eleven dichotomies, and those from the Serratus Rock plot would have only nine dichotomies.

It is clear that rate of forking and elongation-rate are correlated inversely with one another. The more slowly a plant grows, the more rapidly it forks. It appears probable that in both species a reaction to inimical conditions is shown by retarded growth-rate and increased forking. Despite this variation in response to local conditions, especially degree of shelter, there is no doubt that there is an over-all increase in growth-rate and a marked diminution in the 
rate of forking as one moves from the south coast, via the Isle of Man, to the Argyll coast.

After a dichotomy has been established, the two arms develop into frondage, but at very different rates. One arm has the advantage and grows more quickly than the other arm (Figs. 6, 7A). Examination of an old frond may show that more than two-thirds of the total frondage has been developed from one

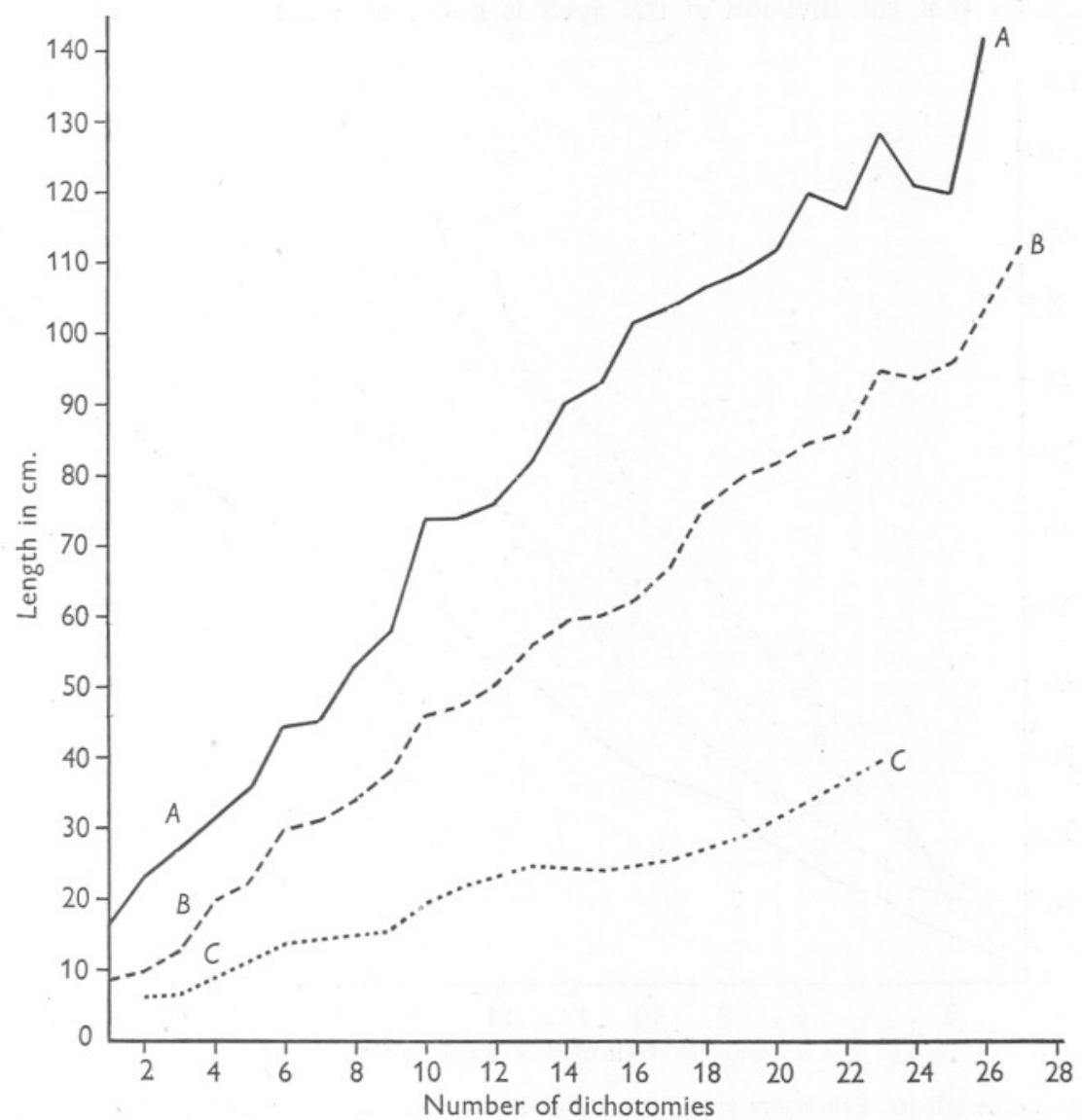

Fig. 4. Length to dichotomy relations in Fucus vesiculosus on the Devon, Manx and Argyll coasts. $A$, Church Reef, Wembury, Devon; $B$, Port Erin, Isle of Man; $C$, Sgeir Bhuidhe, off the west coast of the island of Luing, Argyll.

arm of the first dichotomy. Occasionally, in F. serratus and more rarely in $F$. vesiculosus, the rate of development of the two arms of the first dichotomy is approximately equal and a 'twin-thallus' is formed. This is seen in F. serratus in Fig. 7 B. Fig. Io shows an almost similar condition for F. vesiculosus.

If the dichotomies are followed in sequence along the length of a frond, it will be seen that the emphasis of development of one arm of a fork compared 
with the other shows regular alternation from side to side of the frond. This overgrowth of alternate arms of a fork at successive dichotomies appears to be a fundamental morphological feature of both species, though it is more strictly maintained in $F$. serratus than in $F$. vesiculosus (Figs. 8, 9).

This inequality between the two arms of a fork is obviously due to a difference in growth-potential between the products of division of an apical cell. It suggests that the division of the apex is not a true dichotomy, as it is, for

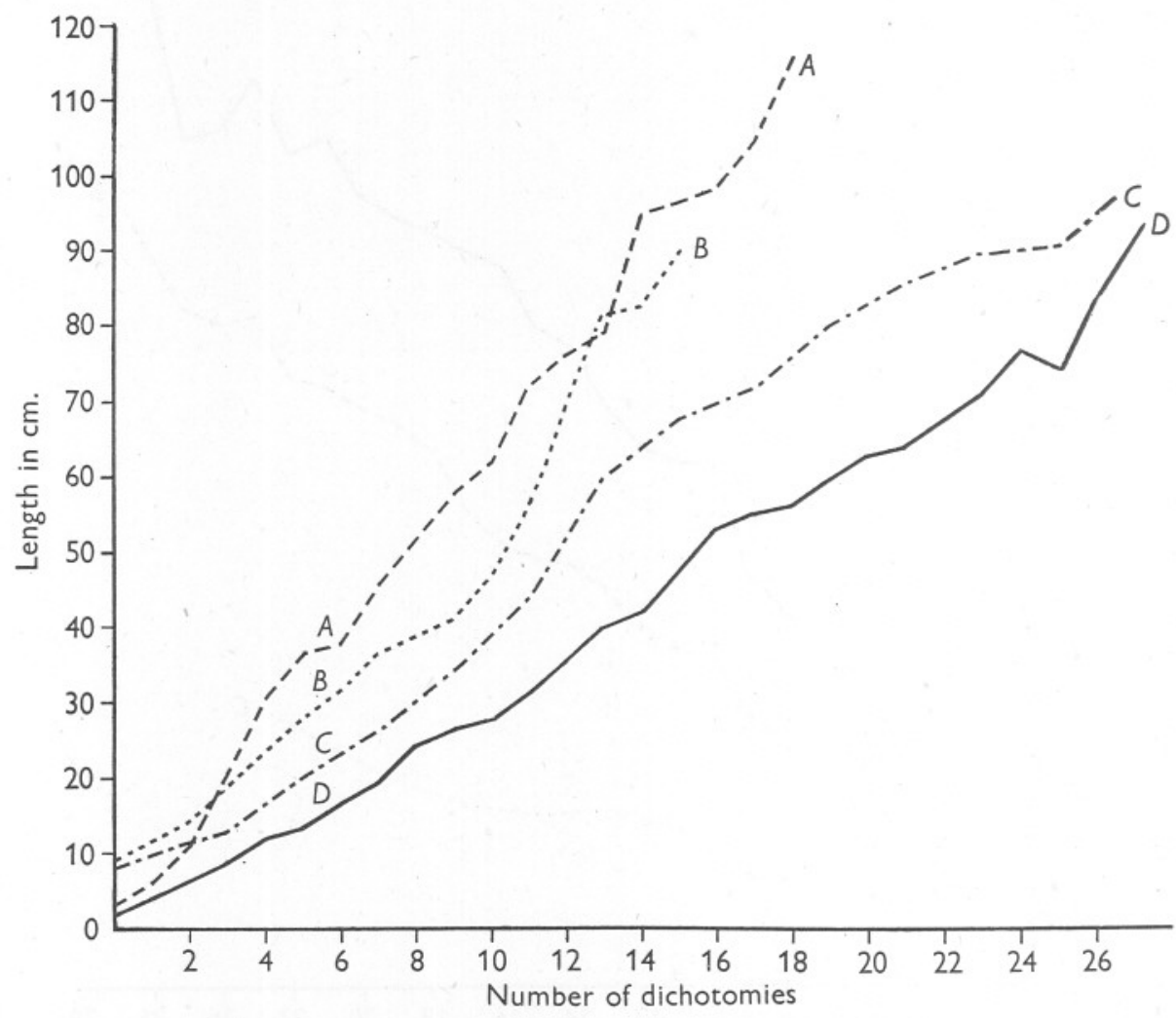

Fig. 5. Length to dichotomy relations in Fucus serratus. A, 'Serratus Rock', off the west coast of the island of Luing, Argyll; $B$, 'Ascophyllum Rock', west coast of the island of Luing, Argyll; $C$, Port Erin, Isle of Man; D, Church Reef, Wembury, Devon.

example, in Dictyota, but that one arm of the fork is due to the activity of a segment cut off from the apical cell which itself serves as the growing point for the other arm of the fork. The inequality of growth-potential would be explained by the excess of vigour of the original apical cell over the segment, to the activity of which the lesser arm of the fork is due. The alternation of excess growth-potential is therefore only an effect of regular segmentation from alternate sides of an apical cell. 
On this view the two species of Fucus under discussion might be regarded as having a monopodial rather than a dichotomous habit of branching, but it is a monopodial system in which the lateral branch initial arises in the immediate vicinity of the apical cell and thus simulates a dichotomy. This method of unequal development of the two arms of a fork is, of course, carried to much greater degree by members of allied families as, for example, the Sargassaceae.

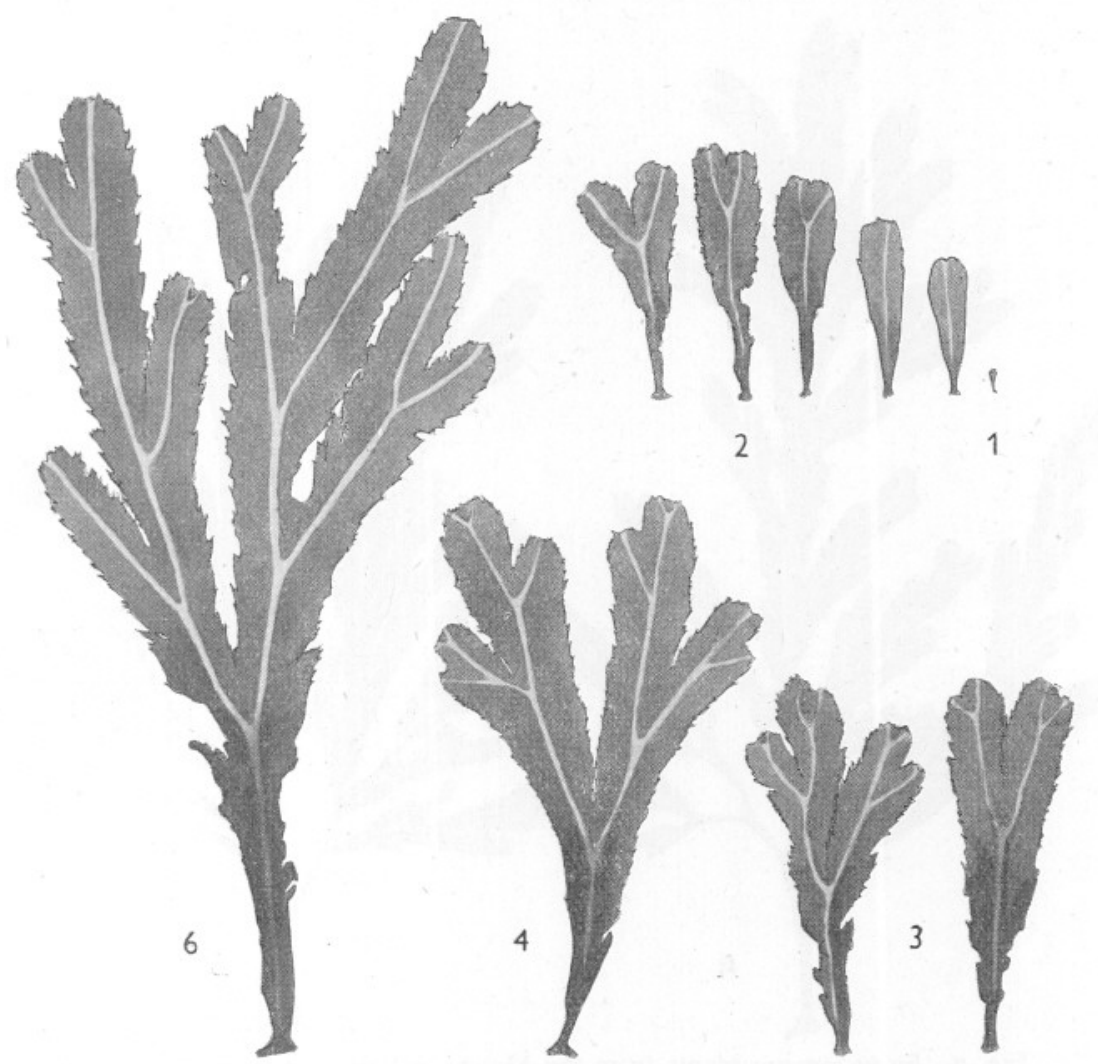

Fig. 6. Germlings of Fucus serratus from I to 6 months in age. $\times 0.27$.

Not only is there an unequal capacity for frond development between the two arms of a fork, but the fate of the frondage developed from the arms may also differ. For example, in $F$. vesiculosus that arm of a fork which has the lower growth-potential usually forms a reproductive fan, forked at short intervals and forming receptacles at the tips of the fronds (Fig. IO). The other arm grows forward as a 'leader' and may give off seriatim, left and right, other reproductive fans. Occasionally one or two apices on the younger reproductive fans may remain sterile and act as secondary 'leaders', repeating the behaviour of the primary 'leaders' and adding to the bushiness of the plant. 
At the time of fruiting, both primary and secondary leaders may be observed projecting beyond the general periphery of the frondage (Fig. IO). It may be noticed that receptacle development has been imposed simultaneously on lateral fronds of different ages. The basal older ones have undergone the greater number of dichotomies and bear the larger number of receptacles. The fruiting fronds will be ultimately removed after fruiting, and the leaders will

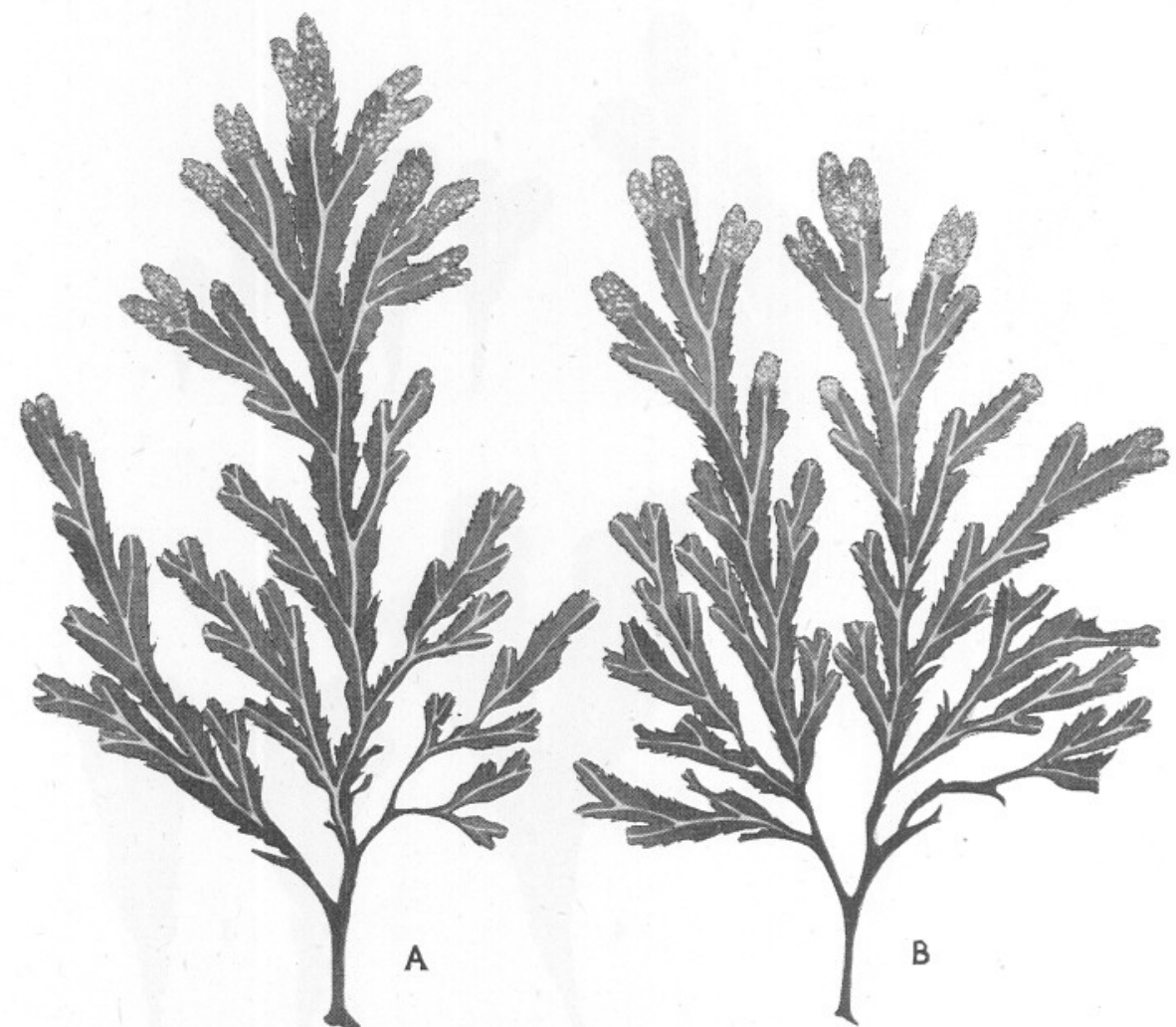

Fig. 7. Fucus serratus plants from the Manx coast showing normal form (A) and 'twin thallus' form (B). $\times 0.23$.

grow forward to produce new distal frondage, with the result that no frondage is left on the proximal part of the plant, except where proliferation may give new frondage from old midribs. The basal part of an old plant, therefore, consists of a tangle of midribs from which the wings have been denuded, beset with spines to mark the places of excised fruiting fronds.

In the development of its frondage, $F$. serratus stands in sharp contrast to $F$. vesiculosus. Each dichotomy shows a different growth potential between the two arms, but the amount of difference decreases from the base of the plant upwards. If the lower dichotomies on a plant are examined it will be found that 
one arm has produced a good deal of frondage but that the other has done very little. It forks only rarely and its growth-rate is extremely slow. In Fig. II only very little frondage has been produced by one arm of the second and third dichotomies. Following the dichotomies upwards it can be seen that there is an acropetal gradient of increasing activity, although the difference in potential between the two arms is maintained. In other words the basal part of the plant has a high degree of latency compared with the distal frondage.

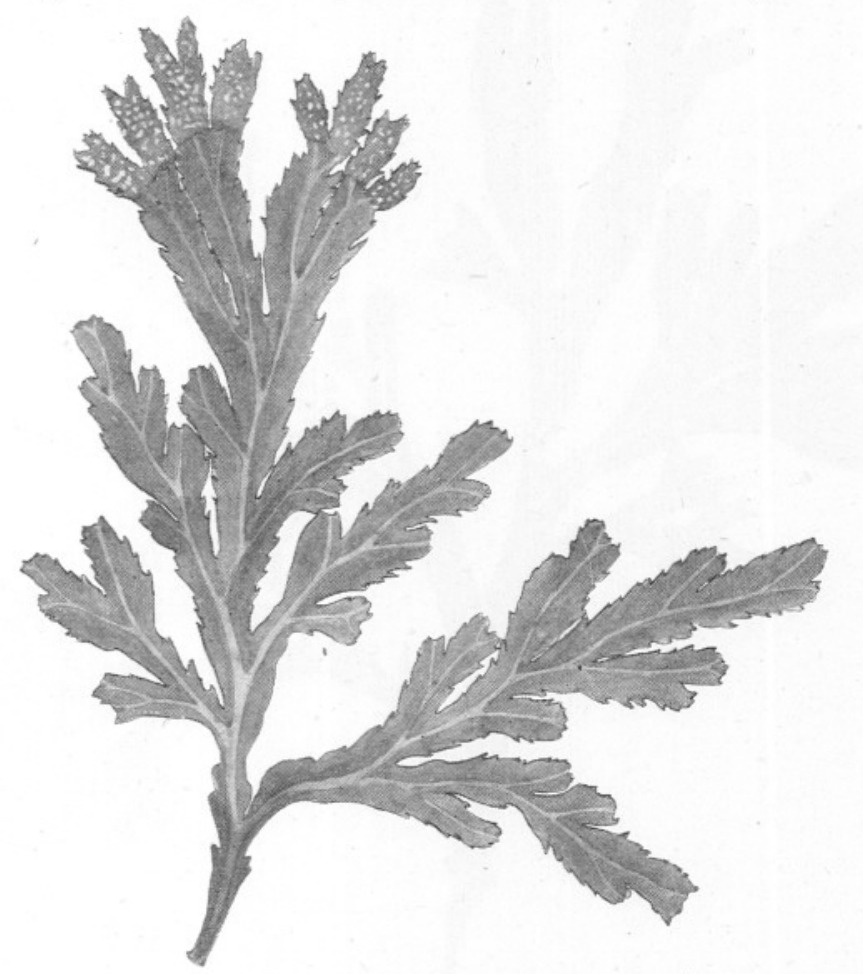

Fig. 8. First year plant of Fucus serratus showing unequal dichotomy. $\times 0 \cdot 27$.

When reproduction sets in, it affects the distal frondage of both arms of the youngest dichotomies and there is no prominent vegetative leader as in $F$. vesiculosus. This is clearly to be seen in Fig. II where receptacles occupy distal positions. When the reproductive frondage is excised, further extension of the frond must take place by the activity of vegetative apices lying below the perimeter of the plant. Vegetative apices lie at all levels on the plant and are of various ages. It is the youngest of these tips nearest to the periphery which first begin to accelerate while the peripheral fruiting fronds are degenerating. After successive fruitings, apices lying at successively lower levels take up the role of elongation, and last of all, if the plant survives long enough, the vegetative apices at the base of the plant. 
In the first year of growth reproduction may not affect all the peripheral tips. Some may remain vegetative, with the result that elongation is a continuous process, but after the second year, when peripheral tips become reproductive, elongation of the plant takes place by a kind of relay system.

The habit of retaining vegetative frondage on the lower parts of the plant gives $F$. serratus a much more bushy form than $F$. vesiculosus. Bearing in mind

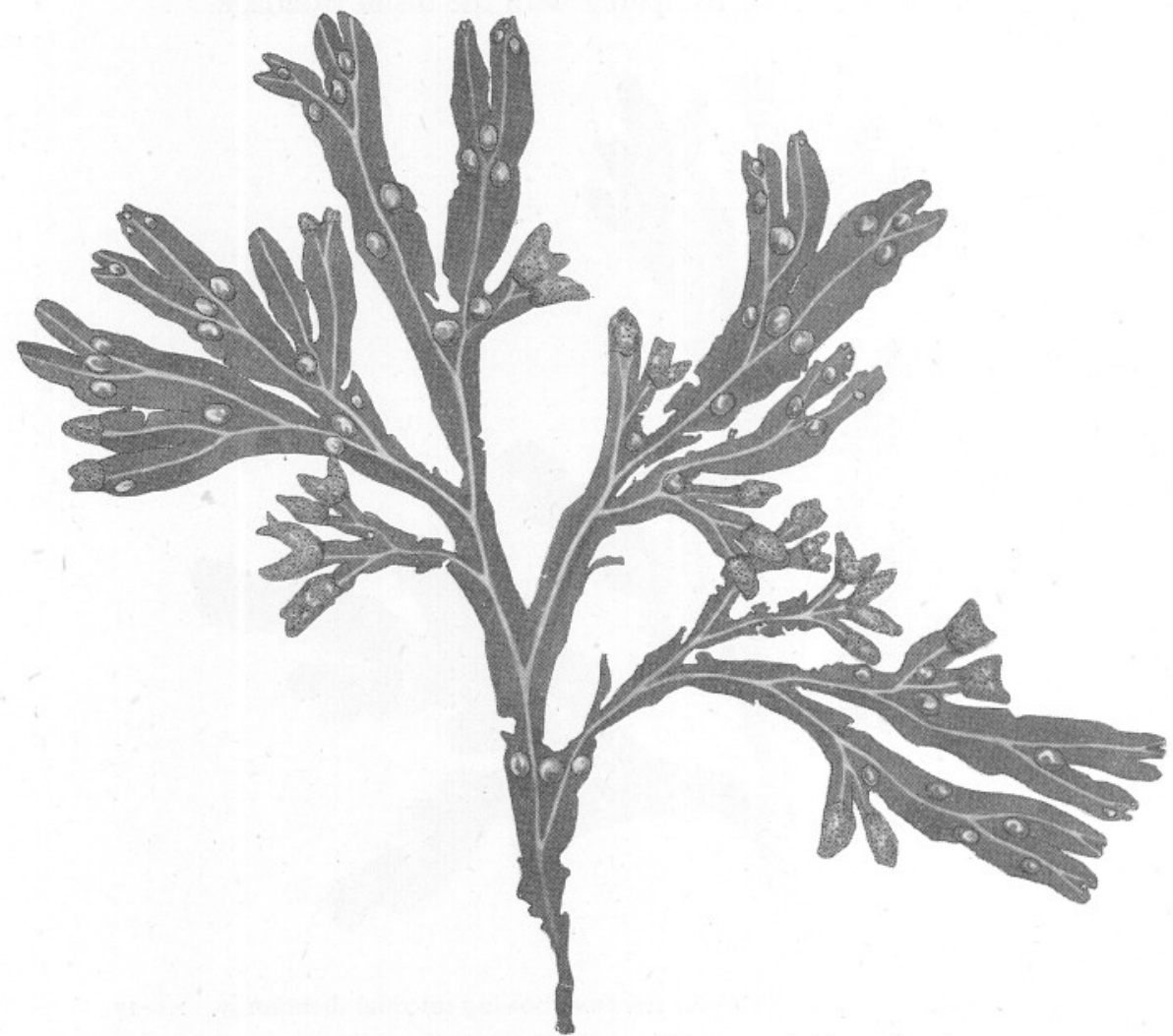

Fig. 9. Eighteen months old plant of Fucus vesiculosus showing unequal dichotomy. $\times 0.21$.

that the behaviour of the main fronds is repeated in the secondary branches it will be realized that the body of an old plant of $F$. serratus is built up on a complicated system of branching.

Comparison between the habit of branching in F. serratus and the sympodial habit of branching of higher plants is inescapable. The similarities which exist between the mechanisms whereby plant form is achieved by plants on land and plants in the sea is striking.

Plants of both species normally live 3 years (Rees, I932) and some may survive a fourth and even a fifth year in very sheltered positions. Plants in the 


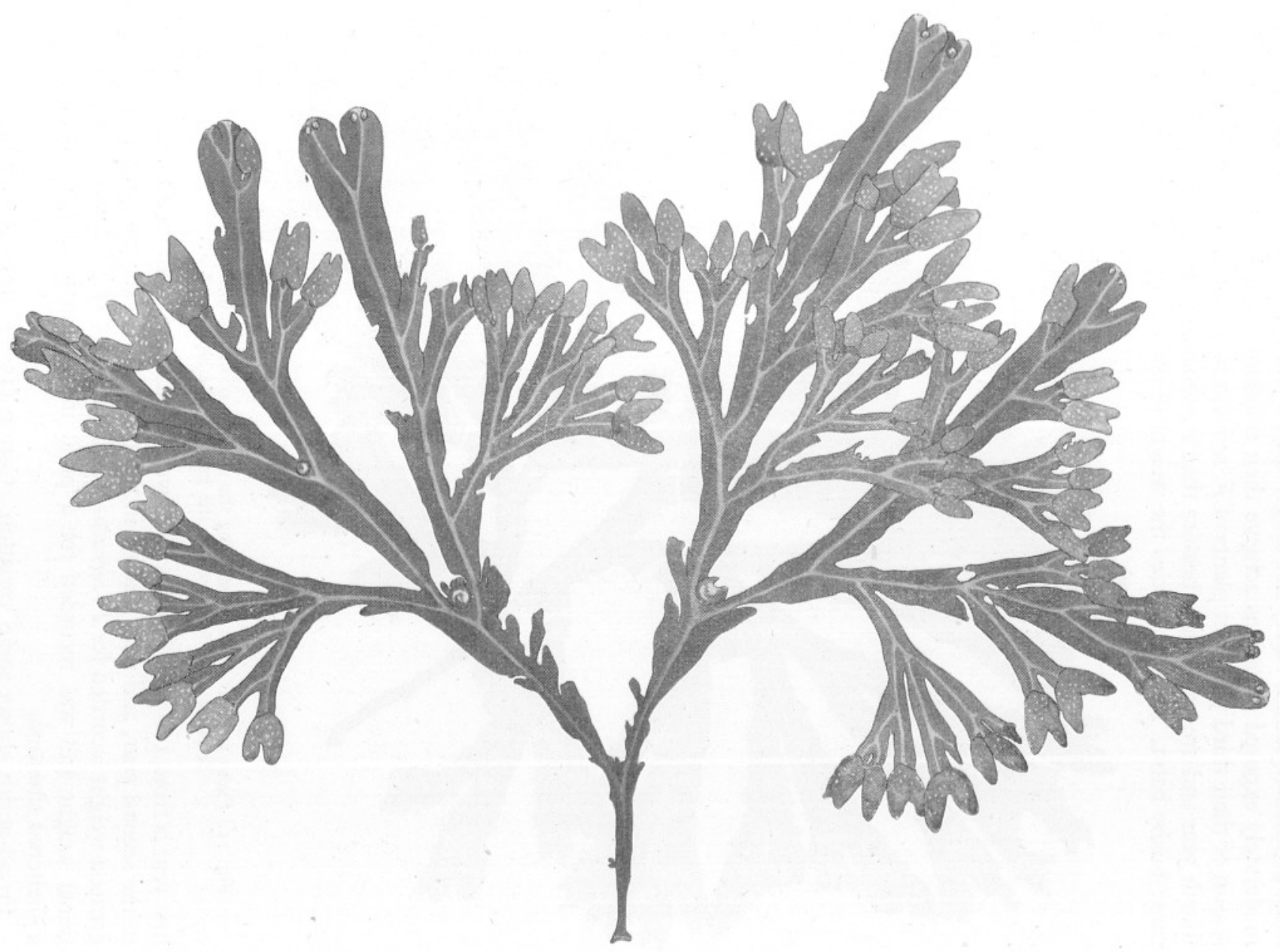

Fig. Io. Plant of Fucus vesiculosus with vegetative leaders extending in preparation for next season's frondage-development. $\times 0.29$. 
most exposed situations rarely live longer than 2 years. $F$. vesiculosus plants in moderately exposed situations achieve their maximum weight in the fruiting season of their third year, but plants of $F$. serratus may gain in weight in their fourth year and are commonly heavier than $F$. vesiculosus on account of their more bushy habit. In both species the weight of the fronds at the end of the

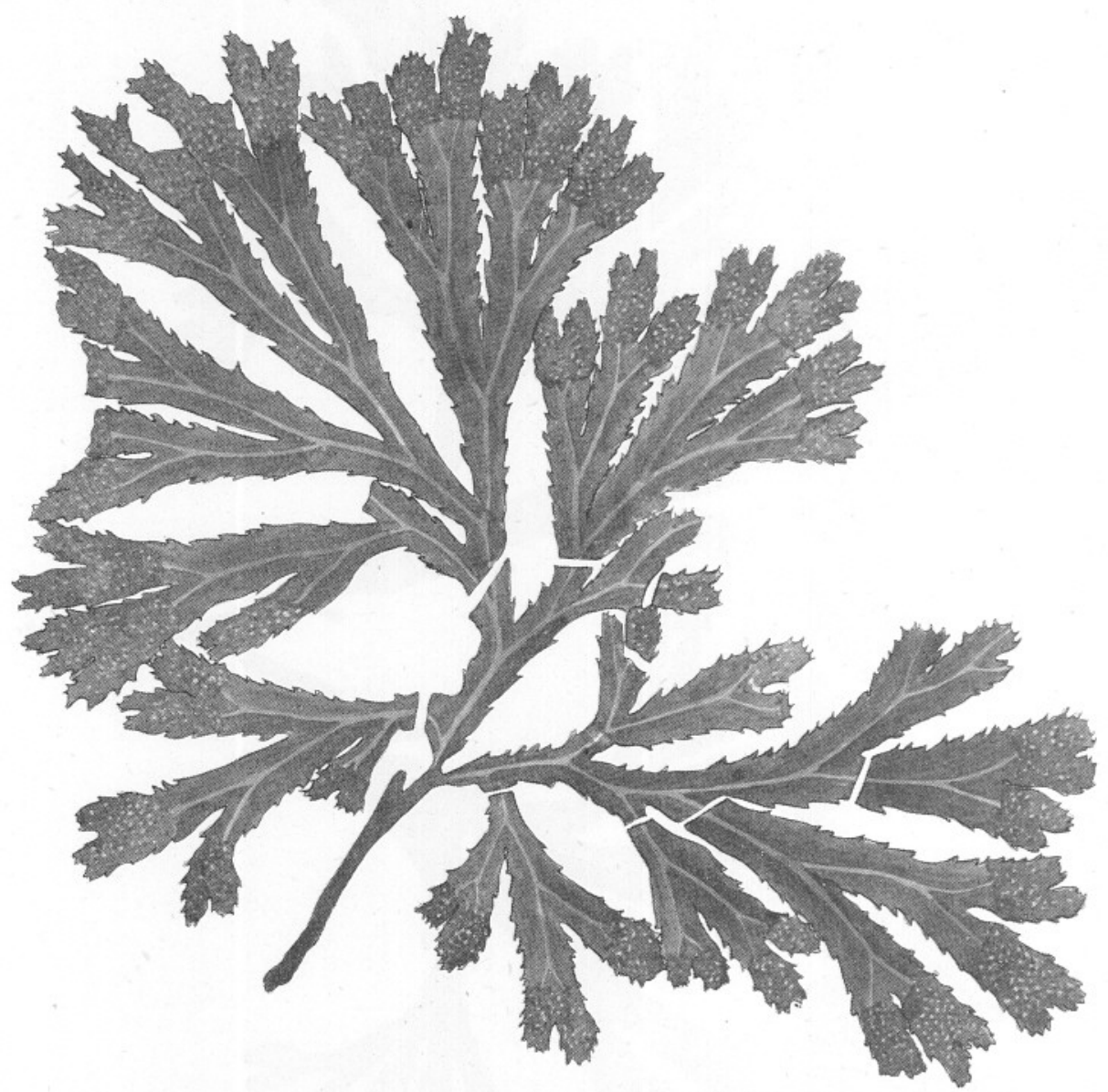

Fig. II. Fucus serratus plant illustrating the amount of defoliation that occurs after fruiting. Fronds distal to the gaps will be shed. $\times 0.27$.

first year is from I to $2 \mathrm{oz}$. ( 28 to $57 \mathrm{~g}$.); weight increases to about I lb. ( $454 \mathrm{~g}$.) in the second year, and rises steeply in the third year to several pounds. The greatest weight recorded for $F$. serratus was $6 \frac{1}{2} \mathrm{lb}$. (2.95 kg.). This is an exceptional weight and was recorded for a plant in its fourth year, growing in a sheltered situation.

Frond-width shows some variation. Cotton (I9I2) suggests that breadth increases with shelter. To a large extent this suggestion has been confirmed 
by observation in the course of the present investigation. It is true that plants of $F$. vesiculosus in extremely exposed places show narrow, dark-coloured and tough fronds. Apart from this generalization, however, there is a great deal of variation in frond-width shown by plants growing even in sheltered situations. Such variation is often accompanied by diversity in number and shape of vesicles and receptacles, and is to be regarded as attributable to factors other than exposure. Broad thalli are commonly found on very young plants, especially where they develop on cleared ground, but frond-width on these young plants may be reduced with each successive addition of frondage. When denudation of the wings of the lower part of the thallus takes place, there may be eventually no sign of the original broad frondage.

\section{VeSICLE-FORMATION IN FUCUS VESICULOSUS}

Vesicles are formed in spring. Appearing in March, the vesicles increase in numbers during April, being added serially by activity of apical tissue (Fig. I2). The great majority of them have been laid down by the end of April, but occasional vesicles may be added in June and July and even as late as August.

The vesicles first appear as minute globular swellings in the wings of the frond, immediately behind the apical notch (Figs. I2, I3). They usually arise in pairs, but a single one is often formed also in the angle formed by a dichotomy. They may occur in the lower internodes of large receptacular fronds.

Plants form vesicles when they have reached a length of from Io to $\mathrm{I} 4 \mathrm{~cm}$. Young plants which have not reached this length by the end of the vesicleformation period postpone the process until the appropriate time in the following year. It is clear that the seasonal process of vesicle-formationa process lasting for a few weeks only-must be brought about by seasonal changes in the physical factors of the environment, but there must also be an internal control which permits of vesiculation in plants at a certain stage of maturity and prevents it in plants below the limit of size.

Speaking generally, vesiculation appears to bear some relation to vertical distribution. This is most marked in the upper limits of the zone, for plants found high on the shore where they are mixed with $F$. spiralis frequently show few vesicles or even none at all. These forms have been considered by some authorities (Cotton, I9I2) to be a distinct variety, $F$. vesiculosus $\mathrm{L}$. var. evesiculosus Cotton. On the coast of Argyll, however, on the Serratus Rock station a high belt of $F$. vesiculosus growing above the Ascophyllum zone bore a conspicuous number of vesicles. An almost complete absence of vesicles characterizes the whole $F$. vesiculosus zone, on the Devon, Manx and Argyll coasts, in very exposed places such as the foot of vertical cliffs exposed to full surfaction. There is a possibility that this condition depends on degree of exposure.

From the point of view of vesiculation, the species shows so much variety that it is difficult to describe what might be considered the normal condition. 
Vesicles may be in pairs with one axillary vesicle, or the latter may be absent. The numbers of pairs in the internodes may vary from one to ten or more. Usually the vesicles are grouped near the sixth internode on young plants and affect one to four of the internodes of each yearly addition of frondage; but there are plants, attributed to a distinct variety, $F$. vesiculosus $L$. var. vadorum Aresch. (Fig. I4), in which vesiculation appears to be a continuous process. As many as ten pairs of vesicles may occur in the length of one internode, and there appears to be no recognizable gap between the sets laid down in

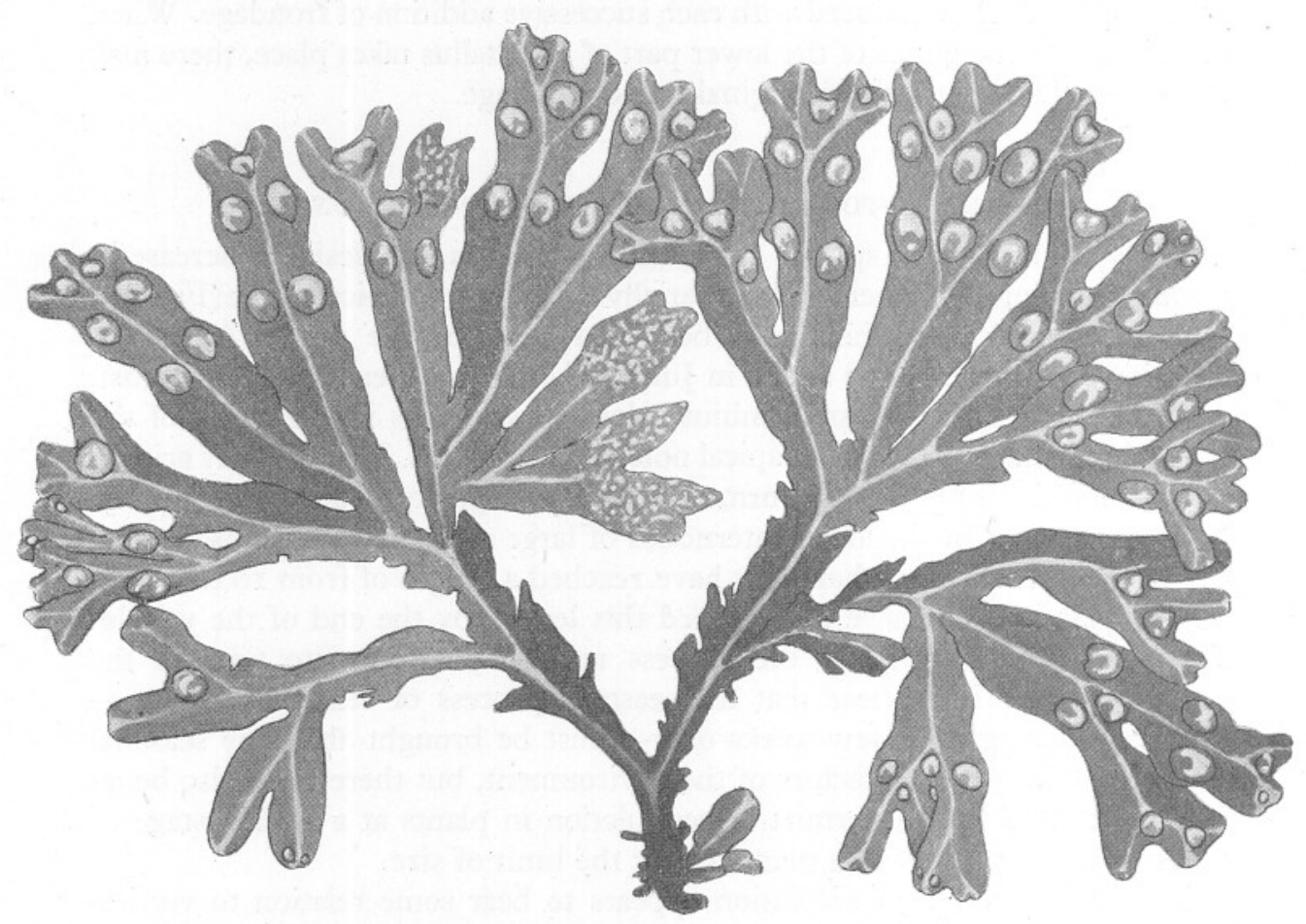

Fig. I2. Vesicle-formation in a plant of Fucus vesiculosus L. in the spring. $\times 0.40$.

successive years. This form is frequently associated with a sheltered habitat, but there is evidence that it occurs also in less sheltered places. It has been suggested that vesiculation increases in less well-aerated waters, but this hypothesis has yet to be proved.

Fig. I3 might be considered as illustrative of the most usual arrangement of vesicles, with one to three pairs in the internode and one axillary vesicle, and with a distinct gap between one set of vesicles and the next. The first vegetative period in the plant's life is marked by the production of the first set of vesicles and the frondage between the two sets of vesicles has been developed in the second year. 


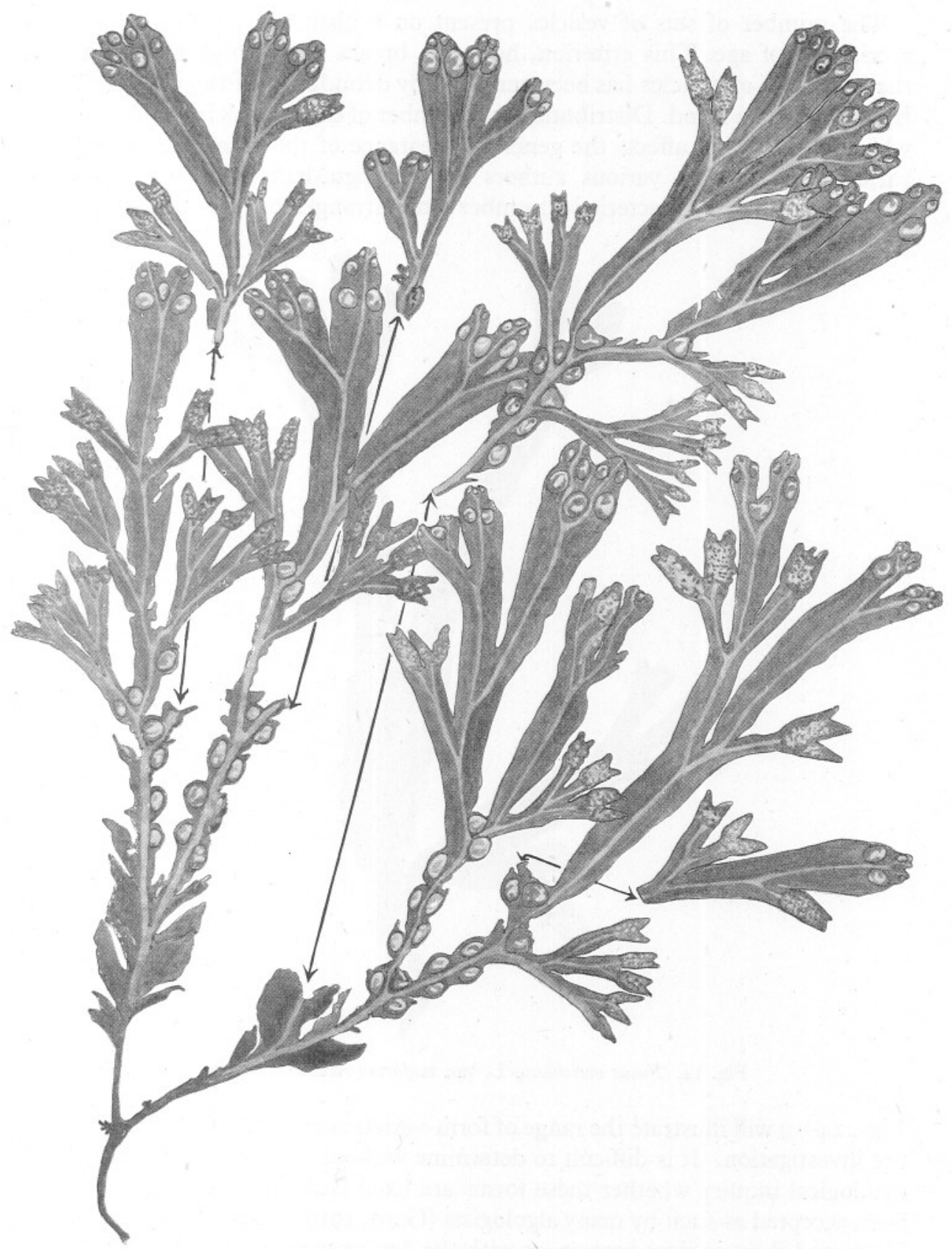

Fig. 13. Plant of Fucus vesiculosus L. with first and second set of vesicles. $\times 0.23$. 
The number of sets of vesicles present on a plant may thus be used as a criterion of age. This criterion, however, breaks down in an old plant, if the lowest set of vesicles has been removed by denudation of the wings of the basal part of the frond. Distribution and number of the vesicles is the character which most greatly affects the general appearance of the plant. Many of the varieties claimed by various authors are distinguished from one another largely by their characteristic number and arrangement of the vesicles.

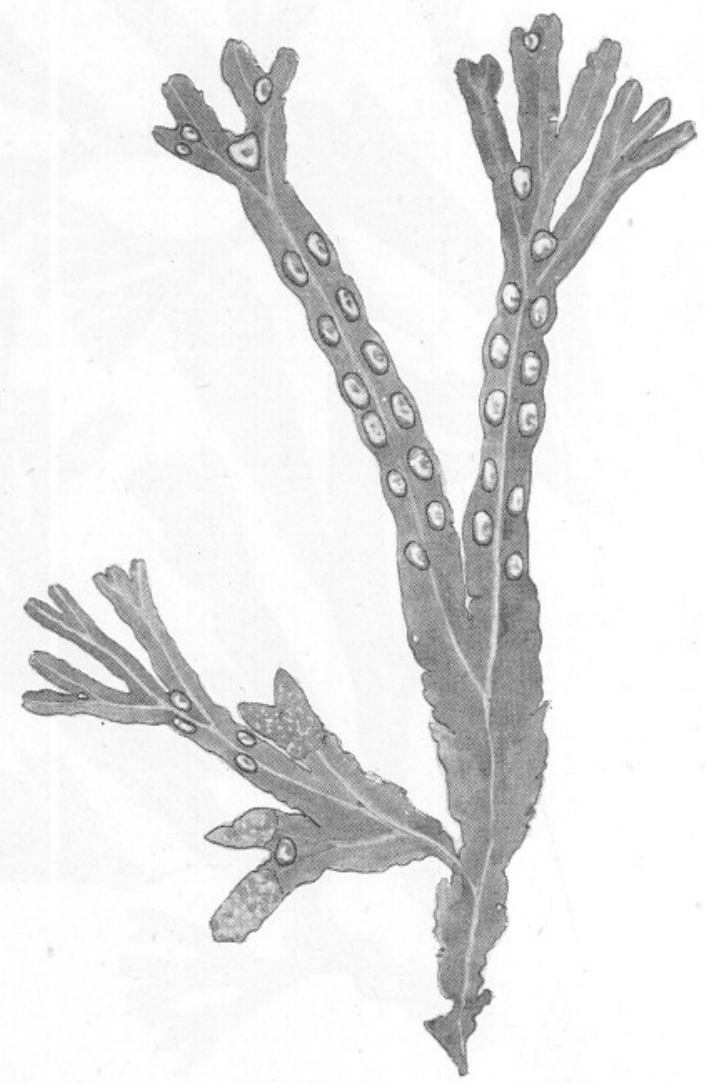

Fig. 14. Fucus vesiculosus L. var. vadorum Aresch. $\times 0.32$.

Figs. I4-I9 will illustrate the range of form-variation met with in the course of the investigation. It is difficult to determine without far-reaching genetic and cytological inquiry whether these forms are fixed varieties or not. They have been accepted as such by many algologists (Gard, I9I6). In some of the forms illustrated there is close agreement with the descriptions of accepted varieties, but the authors have not had opportunity to consult type specimens. Fig. I5 with a single vesicle in the axils of forks and a very wide divergence of 
the arms agrees with the description of $F$. vesiculosus L. var. divaricatus Good. \& Woodw. Similarly, Fig. I4 may be a young plant of $F$. vesiculosus L. var. vadorum Aresch., in larger plants of which there may be as many as ten pairs of vesicles per internode. It is possible that Fig. I6 represents a hybrid between $F$. vesiculosus and $F$. serratus. Such hybrids between the two species are not uncommon; they usually have the vegetative features of $F$. vesiculosus and a receptacle-form more nearly resembling that of $F$. serratus. Fig. I7 represents an unidentified variety which was quite distinct from the evesiculate type characteristic of high levels or exposed coasts. Fig. I8

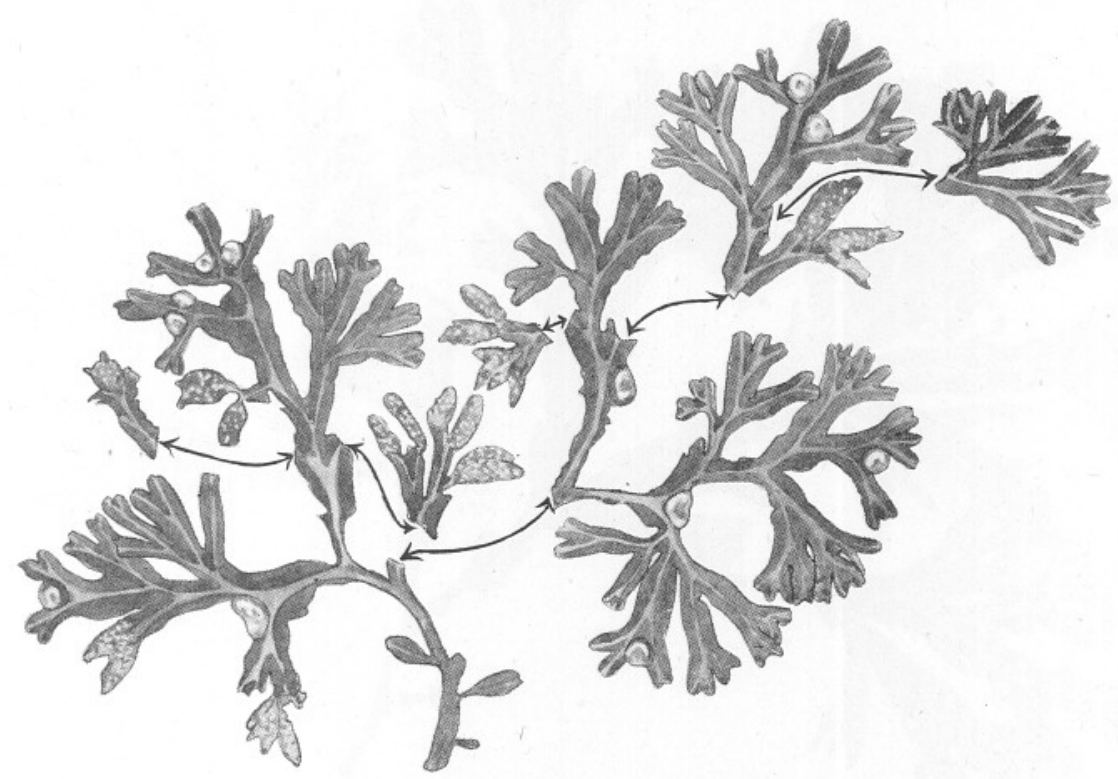

Fig. I5. Fucus vesiculosus L. var. divaricatus Good. \& Woodw. $\times 0.31$.

shows a plant almost without vesiculation but bearing small spherical, airfilled receptacles agreeing in form with the description of $F$. vesiculosus L. var. sphaerocarpus J. Ag.

The presence of fresh water draining down the shore affects the form of plants of $F$. vesiculosus lying in its path. On these plants receptacles are usually greatly distended and water-filled (Fig. I9). The same general character is shown by the $F$. vesiculosus population of the banks of the river Mersey, where the salinity of the water is less than that of the open sea.

It is quite certain that the varieties met with are not all to be explained on the score of ecological growth-forms, due to differences in habitat. It is true that modification in vesiculation in relation to bathymetric level is an observed fact; but such modification is defined in terms of growth-rate and internode length as well as in the presence or absence of vesicles; moreover, the range of 
variation shown in relation to level is much less than that shown by the different habit-forms described for plants growing side by side at the same level in what appear to be identical circumstances. The extreme forms are linked by a series of intergrades. If they are not to be regarded as fixed, separate varieties, the only explanation of their occurrence would be that $F$. vesiculosus is subject to spontaneous form-variation unrelated to the physical factors of the environment.

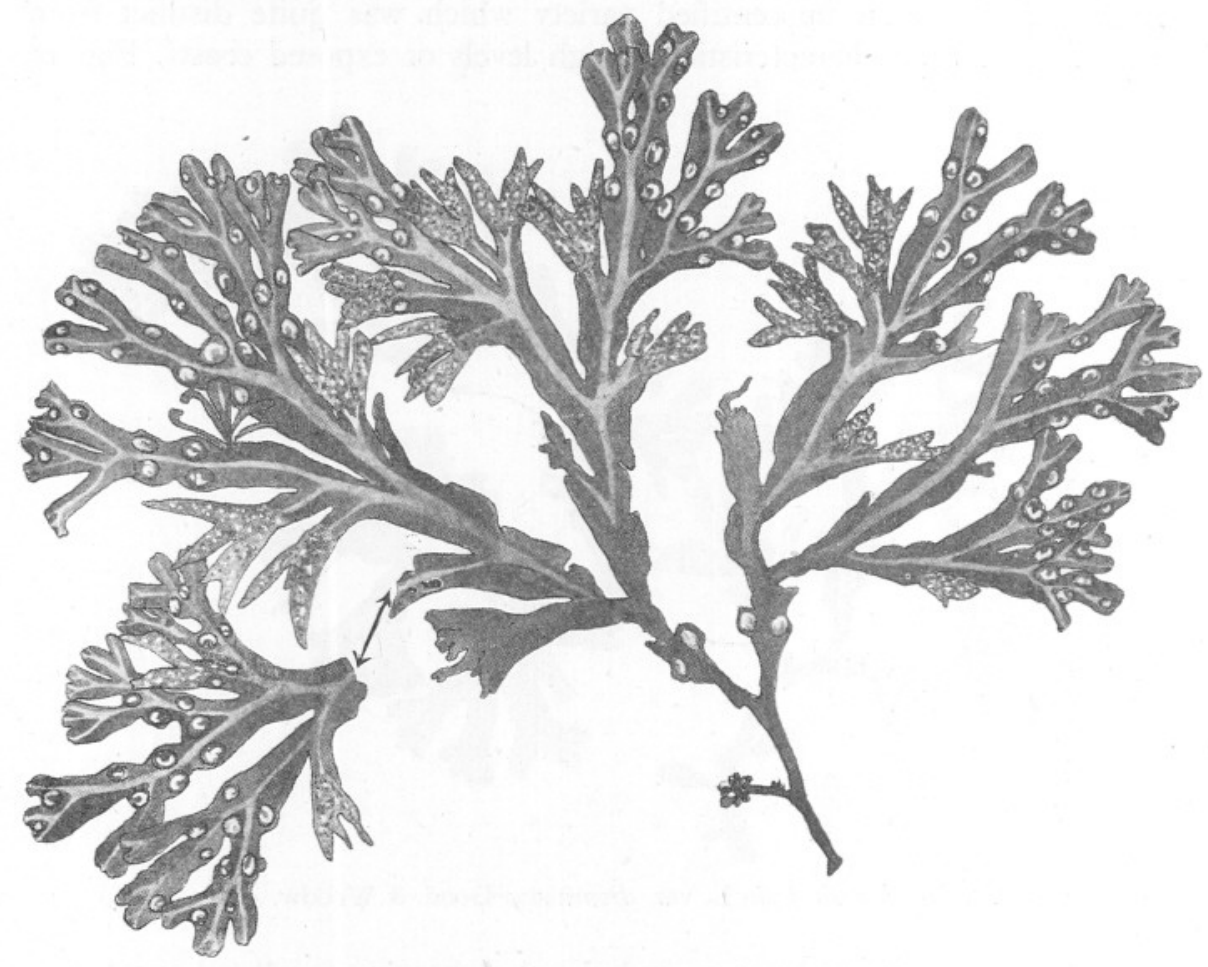

Fig. I6. Suspected hybrid of Fucus serratus L. and Fucus vesiculosus L. $\times 0.27$.

\section{REPRODUCTION}

Reproduction shows a seasonal rhythm. Initiation, maturation of receptacles and retrogressive stages after gamete-release cover a long period. The peak of reproduction is reached in the spring and summer by $F$. vesiculosus, and in the autumn and winter by $F$. serratus, though the latter species shows great variety in the timing of reproduction at various points on the British coasts.

Initiation of receptacles is continued over a period of at least 5 months, and 3 months are required for the development of a receptacle from its initiation up to the stage when gametes are released. 
Receptacle-initiation begins in a few plants at first and only gradually affects the bulk of the population. When the peak of gamete-release is passed, some plants continue the process for some weeks. In general, plants in the upper levels begin to fruit first and plants at lower levels come successively into fruit. The timing of receptacle-formation also appears to be affected by the degree of shelter. In sheltered localities reproduction may be initiated earlier than in

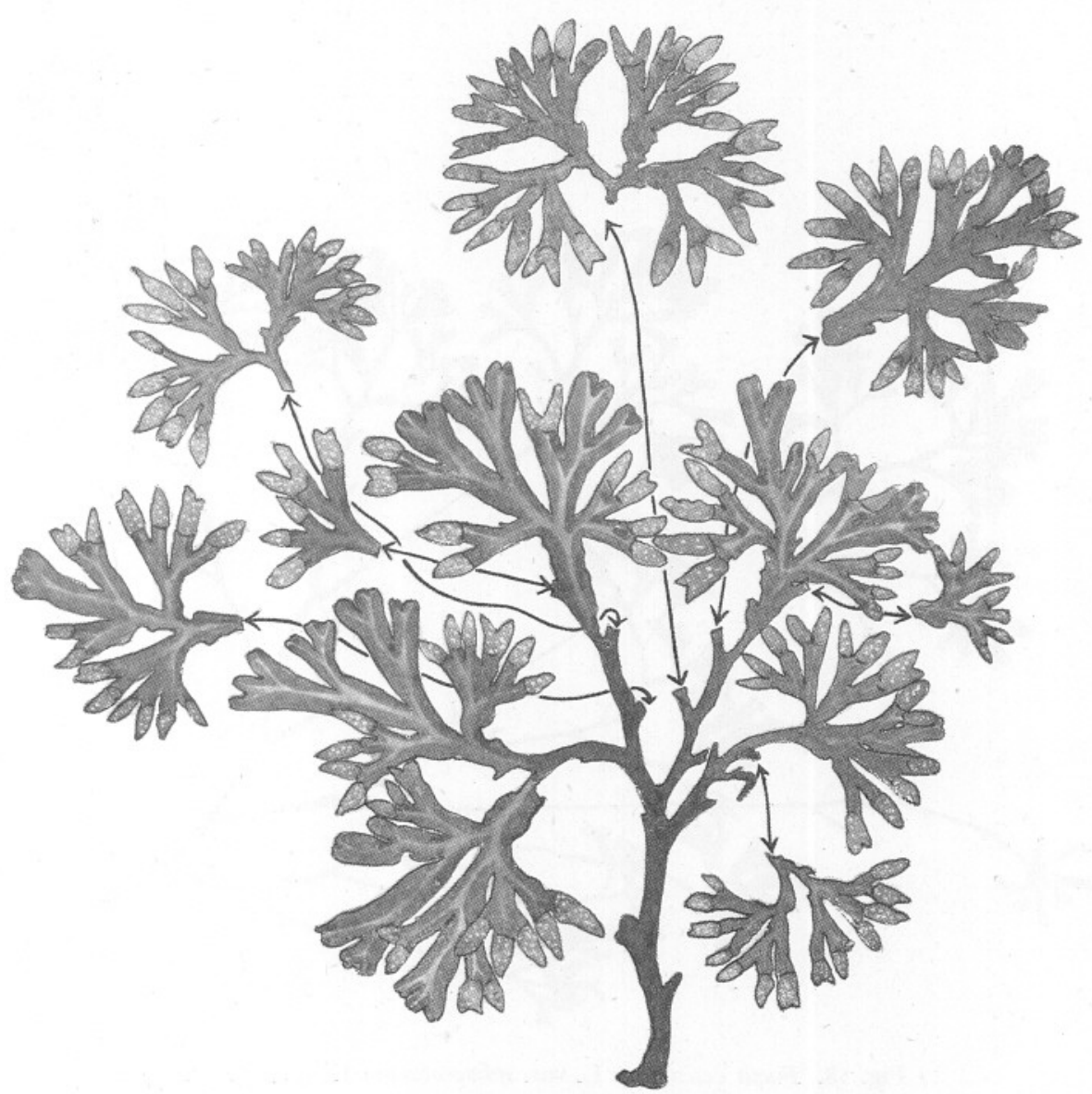

Fig. I7. Unidentified variety of Fucus vesiculosus L. $\times 0.34$.

exposed places, and the reproductive stages may be passed through more slowly, thus prolonging the whole reproductive period.

After initiation of new receptacles is over for the season, those still present on the plant pursue the later stages of retrogression, and some of them may be still present on the plant when the next season's receptacles are beginning to be formed. 
Young plants of $F$. vesiculosus usually reach a length of $15-20 \mathrm{~cm}$. before they form receptacles. The corresponding length for plants of $F$. serratus is $18-25 \mathrm{~cm}$. Only a small proportion of the plants fruit in their first year. On these plants receptacles are few and are developed on the lowest frond branches. Not infrequently, the frondage produced in the first year becomes reproductive simultaneously with the frondage of the second year. First year plants may

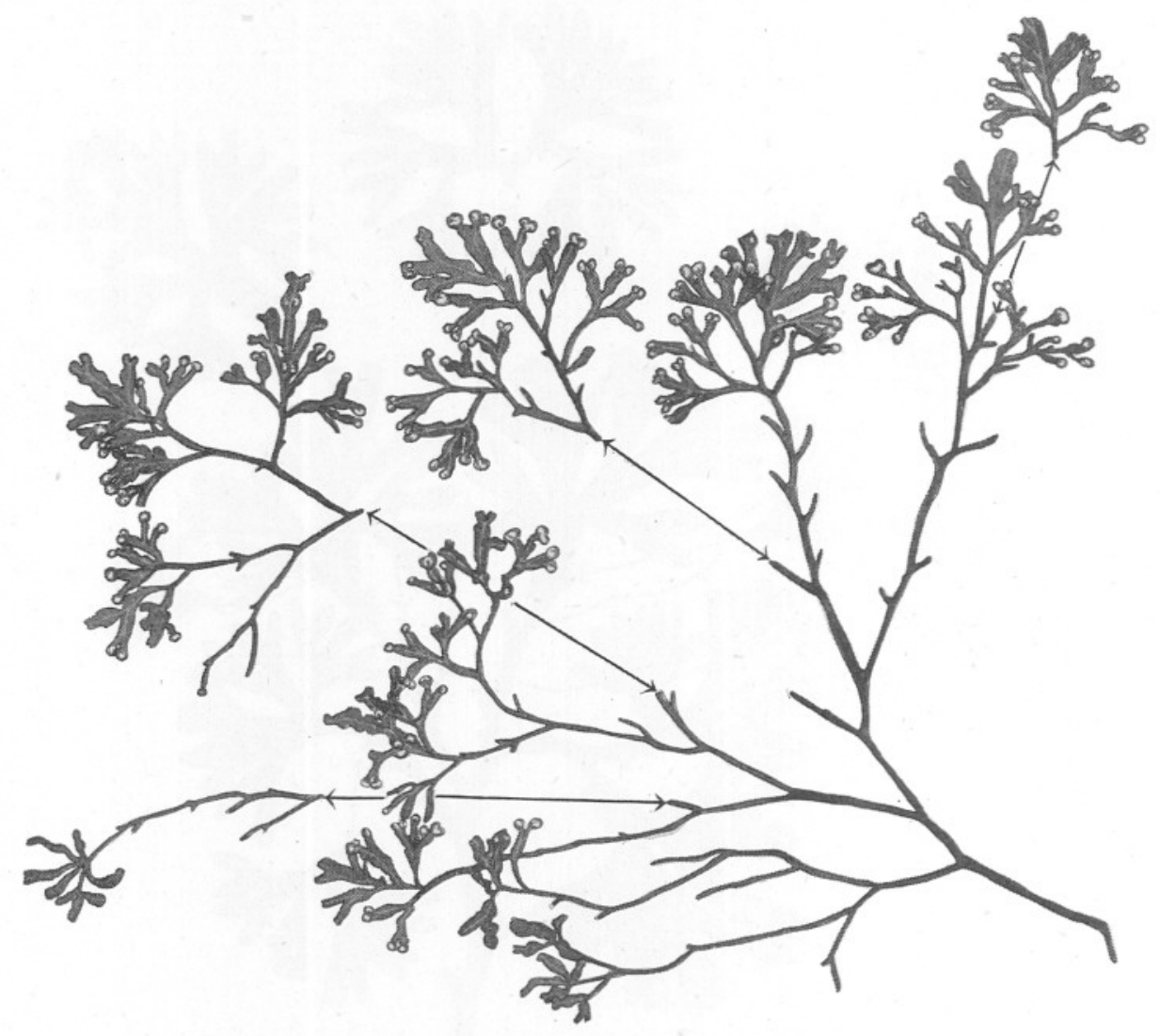

Fig. 18. Fucus vesiculosus L. var. sphaerocarpus J. Ag. $\times 0 \cdot 20$.

reproduce either early in the season before the older plants (Port Erin) or later in the reproductive season after the older plants have fruited (Devon).

The receptacles of $F$. vesiculosus and $F$. serratus differ somewhat in development. The apical cell, giving rise to a receptacle in $F$. vesiculosus, continues activity until the receptacle is shaped, but ceases to divide before the oogonia and antheridia are established in the conceptacles. The apical groove then flattens out, and further elongation and swelling of the receptacle is brought 


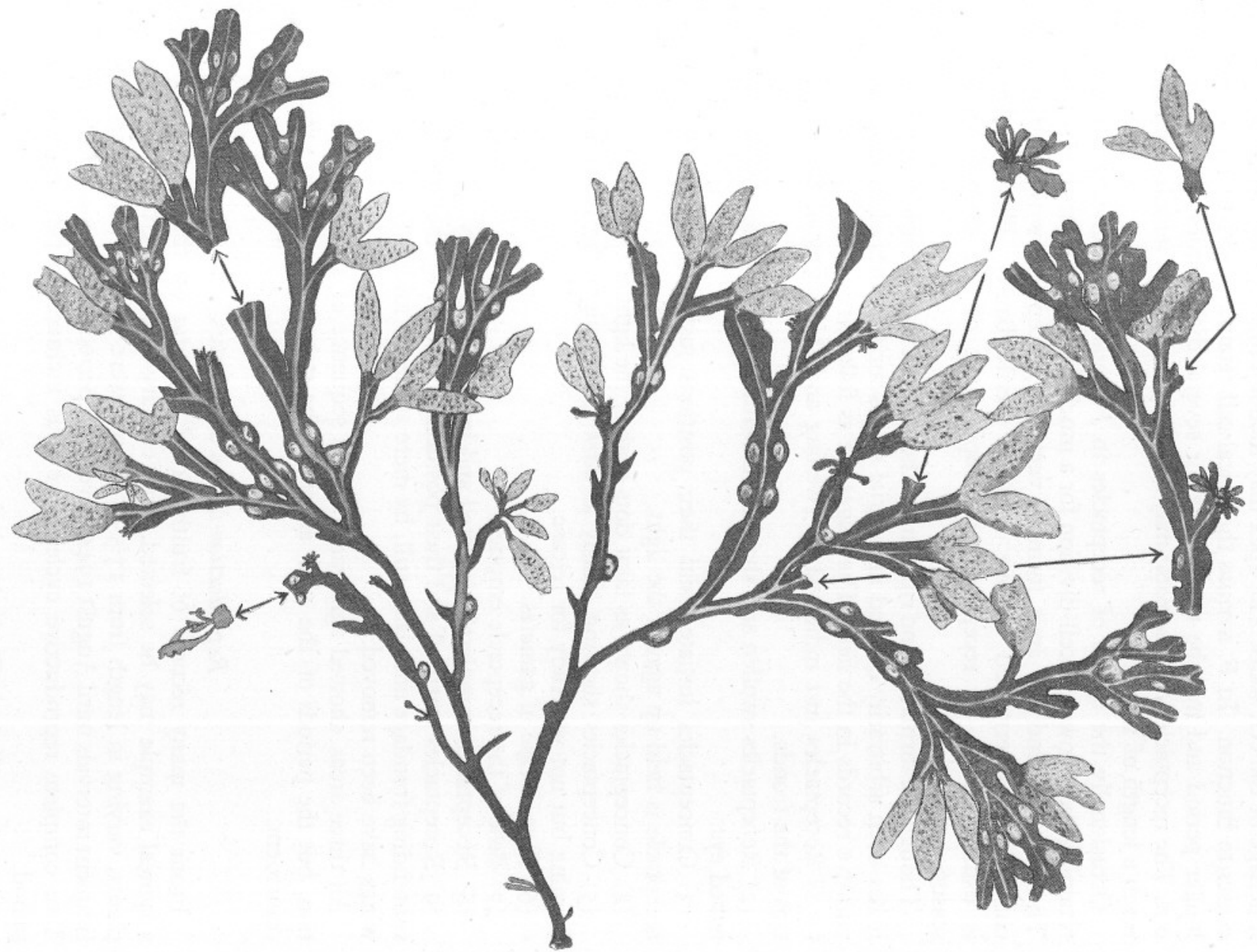

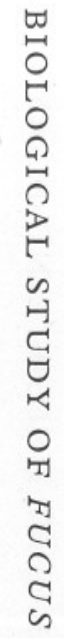

Fig. 19. Plant of Fucus vesiculosus $\mathrm{L}$. showing the influence of fresh water. $\times 0 \cdot 25$. 
about by secondary extension of tissues and by increase in swelling of the mucilage of the cell walls. The apex may dichotomize once or twice before it ceases to function. In $F$. serratus the apical cell retains its activity for a much longer period and may be responsible for several dichotomies before it dies out. The receptacles of $F$. serratus may achieve considerable length; they often reach a length of $\mathrm{I} 4 \mathrm{~cm}$.

Occasionally the apices of receptacles in $F$. vesiculosus show variation by retaining their power of cell-division for a much longer period than is normal. The tissue behind the apex forms a very long receptacle with a series of conceptacles interrupted by one or more sterile bands. This peculiarity is usually shown by receptacles developing out of the normal fruiting season.

Though the formation and ripening of the receptacles is a continuous process, it has been arbitrarily divided into serial stages for purposes of making comparative records in the field. The stages are as follows:

(I) Receptacles just indicated by swelling and thickening of the extreme tips of the fronds.

(2) Receptacles swollen and shaped, but with no conceptacles visible to the naked eye.

(3) Conceptacles initiated and their positions just discernible when the receptacle is held up against the light.

(4) Conceptacles shown as faint dots against the light.

(5) Conceptacles showing clearly as dark dots against the light; gametes forming but not yet ready for release.

(6) Free release of gametes.

(7) Base of the receptacle emptied.

(8) Receptacles completely depleted and beginning to decay.

(9) Receptacles worn off and their positions indicated by the torn edges of subtending frondage and, later still, by mere spines of midrib from which the wings have been removed.

All three areas showed agreement in the sequence of stages in reproduction, but the periods of the year at which the stages were shown were not coincident.

\section{Reproduction in Fucus serratus}

From the many records of fruiting of $F$. serratus on the Devon coast, a typical example may be selected. In February 1942, six groups of young plants, varying in length from 17.5 to $48 \mathrm{~cm}$., were labelled and observed at frequent intervals until August 1944, covering a period of 2 years and 6 months. Two complete reproductive cycles were thus included in the experimental period.

Apart from slight individual variations the groups behaved similarly. The course of reproduction is illustrated by Fig. 20, and details are given in 
the following schedule. The timing of reproductive stages in F. serratus in the Isle of Man is given for comparison:

\section{Comparison of the timing of stages of reproduction of Fucus serratus on the Devon and Manx coasts}

Wembury, Devon

Apr. Thickening observable in tips of fronds of largest plants.

May Initiation of receptacles general in population.

June Initiation of new receptacles still continues. Those formed earliest have reached the stage of forming oogonia and antheridia.

July There is still some initiation of new receptacles. The first gametes are released at the end of the month from the older receptacles.

Aug. Initiation of new receptacles wanes and release of gametes is general.

Sept. No further receptacles are initiated and gamete-release continues. Depleted receptacles show deterioration stages.

Oct. Receptacles formed late in the season

Nov. may be still releasing gametes, but

Dec. deterioration of the majority of the receptacles reaches the last stages.

Jan. Sterile period, though a few old Feb. depleted receptacles may be found Mar. on the plants.
Port Erin, Isle of Man

Aug. A few frond tips show thickening.

Sept. Initiation of receptacles general in population.

Oct. Initiation of new receptacles still continues at reduced rate. The majority of receptacles are approaching maturity and a few have reached the stage of gamete-release.

Nov. No further initiation of receptacles takes place and gamete-release is general in the population.

Dec.) Gamete-release begins to wane and

Jan. all stages in deterioration of depleted receptacles are to be found.

Feb. Very few receptacles still release gametes. Most of them are torn off and the plants present a battered appearance.

Mar. ) Sterile period in which old empty

July receptacles are rare.

On the more sheltered parts of the Manx coast, at Castletown and Port St Mary, receptacle-formation begins in July, nearly a month earlier than on the more exposed Port Erin beach. The peak of gamete-release is also reached a month earlier, but the whole fruiting period is longer than that for plants on exposed beaches, so that the end of the fruiting periods for plants in both habitats coincides.

The fruiting period for $F$. serratus on the Argyll coast begins 3 weeks later than on the Devon coast, and is therefore intermediate in time between that station and the sheltered coasts of the Isle of Man.

Apart from observations made at the three stations under discussion, there is evidence that the range of times of fruiting of $F$. serratus may be considerably extended elsewhere. Plants of $F$. serratus in full release of gametes have been observed on the Northumbrian coast in July, a date earlier than for any other station. 
The degree of fruiting, i.e. the number of receptacles per plant and the proportion of plants in fruit simultaneously in the population, varies from one station to another. From the records, it appears to be heaviest in exposed places. At Port Erin in December, just after the peak of gamete-release, the average percentage of the population bearing receptacles was 6o. On a strip running right through the $F$. serratus zone the proportion of fruiting plants varied from 40 to $70 \%$, being heaviest in the lowest third of the strip. The records from Wembury do not show so high a proportion of plants in fruit. The discrepancy may be due to the fact that a much larger proportion of young plants fruit in their first year on the Manx than on the Devon coast.

Comparison of the proportions of fruiting to sterile tips per plant on the two stations shows a much higher percentage of receptacles on the Manx plants.

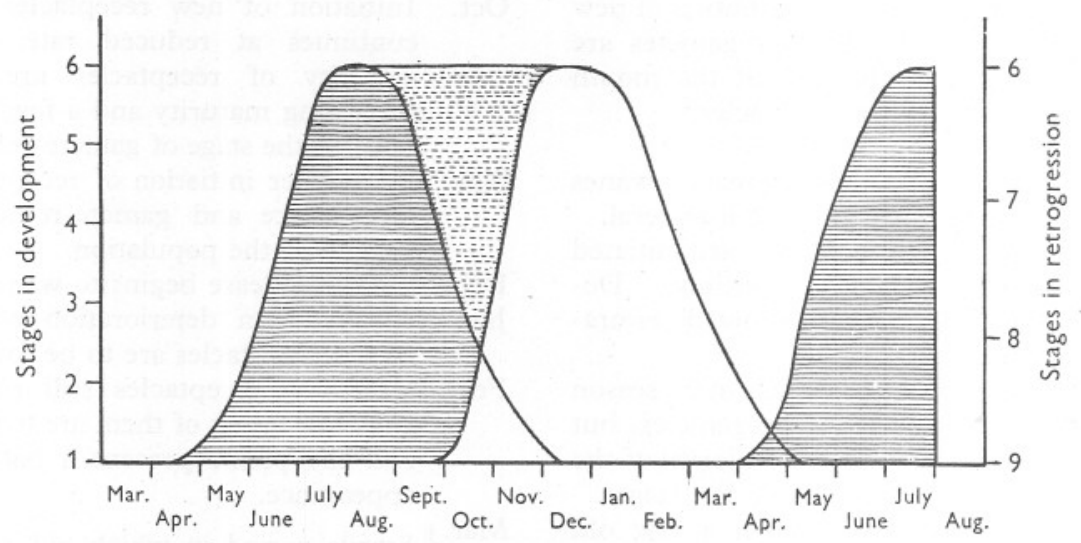

Fig. 20. Seasonal fruiting in Fucus serratus on the Devon coast. See p. 474 for definition of stages.

In many 3-year-old plants, only $5 \%$ of the tips remain sterile; individuals have been found also in which every apex has been transformed into a receptacle (Fig. 26, p. 485). Fig. 2I shows a typical young plant from Port Erin, fruiting for the first time when it was only ro months old. Fig. 2 (p. 454) illustrates a plant from the Devon coast which has not yet fruited though it is I year and 2 months old. Fig. 22 shows a plant of $F$. serratus from Wembury fruiting for the first time in its second year; the receptacles on the plant represent $58 \cdot 7 \%$ of the total frond-tips.

\section{Reproduction in Fucus vesiculosus}

The series of stages in the reproduction of $F$. vesiculosus and the length of time required for their development correspond with similar data for F. serratus, but the timing of reproduction is different for the two species. 
A comparison of the timing of equivalent stages in reproduction of $F$. vesiculosus on the Devon and Manx coasts follows:

\section{Comparison of timing of stages of reproduction in Fucus vesiculosus on the Devon and Manx coasts}

\section{Wembury, Devon}

Dec. Earliest stages in receptacle formation observable in some of the plant population.

Jan. Initiation of receptacles general in the population.

Feb. Older receptacles swollen and shaped. Initiation of new receptacles is continued.

Mar. A few new receptacles may be formed but the majority have advanced to the stage when conceptacles are just discernible.

Apr. No further initiation of receptacles. Antheridia and oogonia formed in older receptacles.

May Full release of gametes.

June Many receptacles show deterioration stages and the youngest are releasing gametes.

July Release of gametes comes to an end and receptacles show all stages of disintegration.

Aug. Only depleted and decayed receptacles present.

Sept.) Sterile period.

Nov. A few tips may show the earliest stages of receptacle-initiation.

\section{Port Erin, Isle of Man}

Dec. Earliest stages of initiation shown by plants of less than I year old.

Jan. General initiation of receptacles on plants of all ages.

Feb. New receptacles still being formed. The older ones show the positions of conceptacles.

Mar. No further initiation of receptacles, but those already formed may have reached the stage of gameteformation. Release of gametes begins.

Apr. Release of gametes increases towards the end of the month.

May Gamete-release passes its peak and June the older receptacles show all stages in deterioration.

July Io $\%$ of the population may still be releasing gametes and the rest bear depleted receptacles.

Aug. Plants releasing gametes fall to $3 \%$ of the population. Receptacles in the rest of the population are fast disappearing.

Sept. | Fruiting finished. Initiation of new

Nov. Ireceptacular fronds.

There is only about I month's difference in the timing of reproduction on the Manx and Devon coasts. The Devon plants begin first (Fig. 23 and Table XXXIII, facing p. 5I4). Another point of difference lies in the reproduction of young plants. On the Devon coast they usually bear receptacles late in the season, after the main population is in fruit. On the Manx coast, the fruiting of young plants usually precedes that of the older plants. There is also, as was described for $F$. serratus, a precocity of fruiting shown by plants in sheltered situations. On the promontory of Langness on the south-east coast of the Isle of Man, where there is considerable shelter, the factors of the environment combine to make the locality particularly favourable to algal development. Not only do young plants grow more quickly in this area, but they come into fruit at least 3 weeks earlier than on any other area. This precocity is hard to explain unless it be that a river about a mile away may contribute extra organic 
nutrient matter to the sea water in the neighbourhood. The set of the tides is such that mud in very small quantities is carried by the tide and deposited above the algal zone. The mud is just sufficient to support a very narrow belt of saltmarsh.

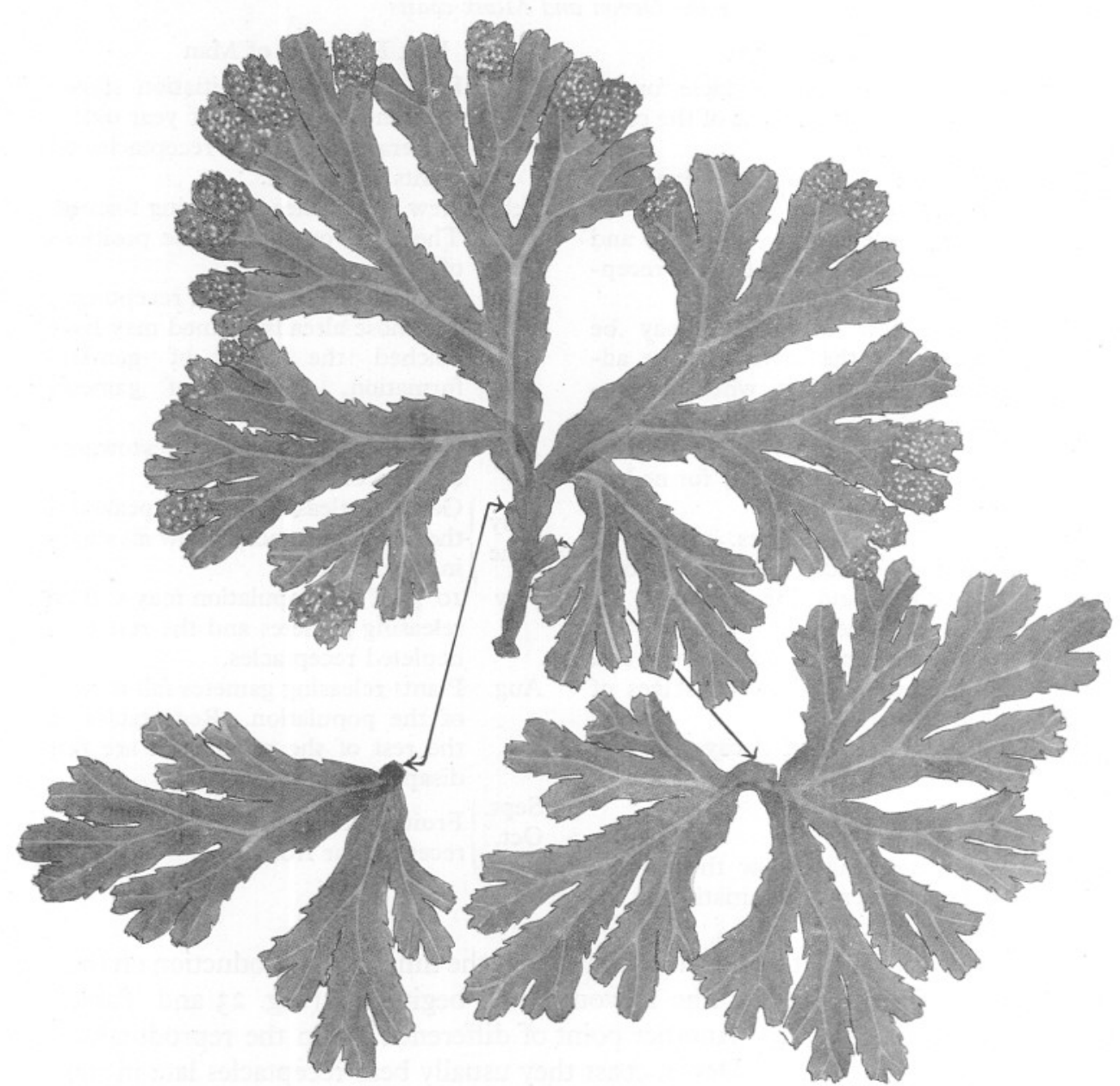

Fig. 2I. Plant of Fucus serratus from the Manx coast showing distal fruiting in the first year. $\times 0.29$.

With $F$. vesiculosus as with $F$. serratus a higher proportion of young plants fruit within the first year on this coast than on the Devon coast. Clearance was effected, in the first week of August, of a strip running through the $F$. vesiculosus zone. Analysis of the new population 37 weeks later showed that $70 \%$ of young plants over $\mathrm{I} 4 \mathrm{~cm}$. in length bore receptacles. The fruiting branches bore only one or two receptacles. In the second and succeeding years the number of pseudo-lateral fronds destined to bear receptacles increases greatly, 

thus raising the proportion of fruiting to vegetative tips on the plants. Fig. 24 showing a plant from the Devon coast, illustrates the appearance of plants preparing for reproduction in the second year of growth. Some of the vegetative leaders, by the activity of which next year's frondage will be developed, are projecting, and the shorter, much divided fronds will develop receptacles in the current season.

The proportion of fruiting tips in the third and fourth years may be very high, usually reaching $80-95 \%$ of the total frondage. Some very bushy forms with a relatively low growth-rate may have very few vegetative tips left after fruiting, to carry on development for the following year. Fig. I7 (p. 47I) illustrates a plant in which only I $8 \%$ of the frond tips remain in a vegetative

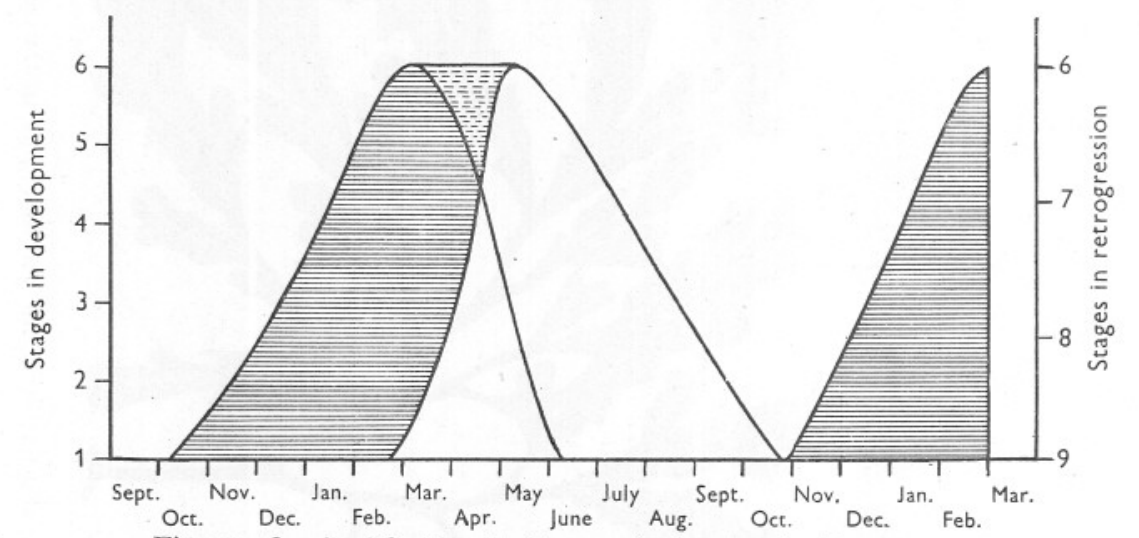

Fig. 23. Seasonal fruiting in Fucus vesiculosus on the Devon coast. See p. 474 for definition of stages.

condition. Fig. 25 shows a plant with only six vegetative tips left out of a total of 158 .

Except on very exposed localities on the Argyll coast, the time of the fruiting period for $F$. vesiculosus coincides with that for the Devon coast. In exposed places, the plants reach maturity, a month later, at approximately the same time as plants in sheltered localities on the Manx coast.

The sequence of normal phases of behaviour for $F$. vesiculosus on the Manx coast is summarized below:

Jan. The main leaders project beyond the pseudo-lateral fans, which have completed their dichotomies in preparation for receptacle-initiation. Receptacles have been initiated.

Feb. Leaders still undergo extension. New receptacles are still being laid down, but the oldest have reached stage 3. Vesicle-formation may be initiated in a few individuals.

Mar. Most of the new receptacles have been laid down and release of gametes begins from the oldest receptacles (stage 6). Vesicle-formation becomes more marked.

Apr. Vesicle-formation is general. The receptacles are releasing gametes. Initiation of receptacles ceases. 
May The peak period of gamete-release is reached and passed. Leaders have now developed pseudo-lateral fans which are in process of dichotomy at short intervals.

June Gamete-release wanes. Old receptacles have reached stage 7. The form of next season's receptacular fronds is discernible.

July Decay of old receptacular fronds takes place. Many turn yellow and are shed.

Aug. Deterioration of old receptacles is nearly complete. New pseudo-laterals have developed into large fans which form the most conspicuous part of the vegetation, and hide the remains of old fruiting fronds.

Sept. A few old receptacles in stage 8 may still be found. New frondage grows in length.

Oct. Final disappearance of old receptacular fronds and further enlargement of new fans.

Nov. Pseudo-lateral frondage prepares for initiation of new receptacles.

Dec. Tips of lateral fronds begin to thicken for receptacle-formation.

The data for this schedule are drawn from the experiments on the Manx station. The schedule would be applicable to the Devon station if the sequence were shifted back about I month.

\section{Defoliation}

When fruiting is over for the season, both species rid themselves of all frondage which has fruited. The amount of such frondage dependent on the degree of fruiting may be considerable. When the gametes are all shed from a receptacle, it becomes gelatinous and open to the attack of fungi and animal parasites. It is readily rubbed off by friction against the rock, but actual necrosis of tissues also takes place. Necrosis starts in the receptacle but extends to the subtending internodes. The latter are not under control of an apical cell because the apical cell dies out in the later stages of receptacle-formation. Necrosis works basipetally downwards crossing forks if both arms have borne receptacles and is arrested only when it reaches a fork, one arm of which is still provided with a functional apical cell, however distant. In this way all fruiting fronds are shed; all that remains is the axis bearing vegetative apices from which next season's frondage will be developed. Fig. II (p. 464) shows a plant of $F$. serratus fruiting for the first time. The gaps in the illustration indicate the frondage which will be shed. New frondage will be produced from vegetative apices while deterioration of receptacular fronds goes on; in the specimen illustrated all new fronds will originate from the half-dozen apices left on the plant. On the Manx coast fruiting in F. serratus is heavy, and it sometimes happens that all the apices may produce receptacles. The plant then pays the penalty of $100 \%$ reproduction, being left without a vegetative leader for the production of new frondage (Fig. 26).

The process of defoliation is more gradual in $F$. serratus than in $F$. vesiculosus. In the former species, after reproduction, the frondage shows broken ends and has a very battered appearance for about a month until the upgrowth of new frondage hides the broken ends. The final stages of deterioration are completely hidden under cover of the new frondage which now becomes the most conspicuous feature of the vegetation. 


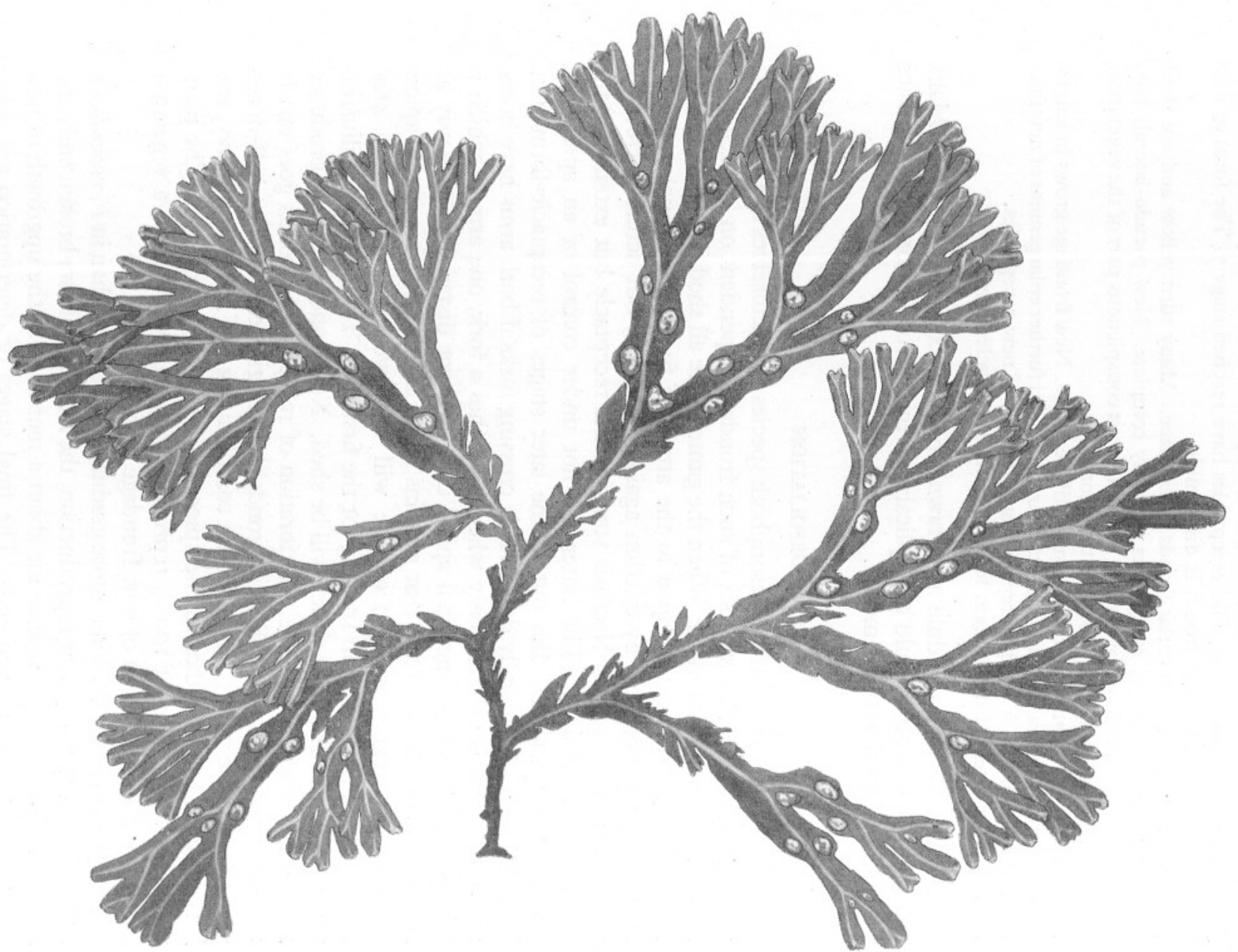

Fig. 24. Plant of Fucus vesiculosus from the Devon coast preparing to fruit for the first time in the second year. $\times 0 \cdot 275$. 
In $F$. vesiculosus the pseudo-lateral fronds turn yellow after fruiting. The colour change affects the whole fan simultaneously (Fig. 27); the frond becomes

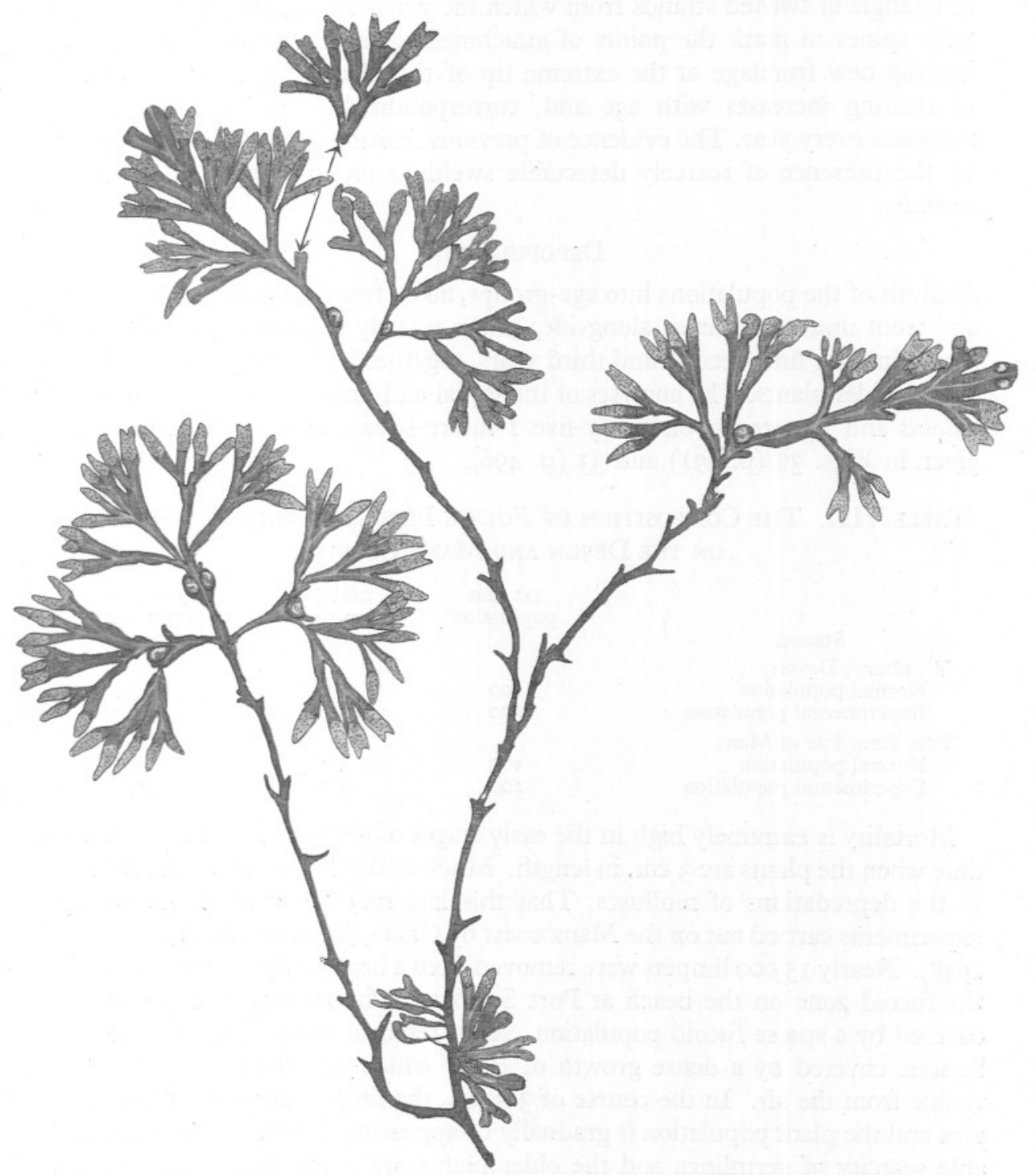

Fig. 25. Plant of Fucus vesiculosus with spines' showing the position of excised fronds. Six vegetative leaders only remain. $\times 0.23$.

limp and gelatinous (Fig. 28) and is ultimately shed more rapidly than that of $F$. serratus. During the deterioration stages the new frondage from terminal leaders and from vegetative apices lower on the plant cover the old 
fruiting fans, and the effect of defoliation is not so evident as in F. serratus. An old plant of $F$. vesiculosus which has fruited several times usually consists of a tangle of twisted strands from which the wings have been denuded, beset with spines to mark the points of attachment of earlier fruiting fronds and bearing new frondage at the extreme tip of the plant (Fig. 25). The degree of fruiting increases with age and, correspondingly, the loss of frondage increases every year. The evidence of previous fruiting on an old plant is given by the presence of scarcely detectable swellings on the length of the main strands.

\section{Depopulation}

Analysis of the populations into age-groups, taken from the experimental areas and from untouched areas alongside, shows a fairly consistent proportion of plants in their first, second and third years, together with a very small proportion of older plants. The analyses of the initial and final populations of $F$. vesiculosus and $F$. serratus on thirty-five I-metre-square areas at Wembury are given in Figs. 30 (p. 49r) and 33 (p. 496).

\section{Table VIII. The Composition of Fucus Populations in Year-Classes on the Devon and Manx CoAsts}

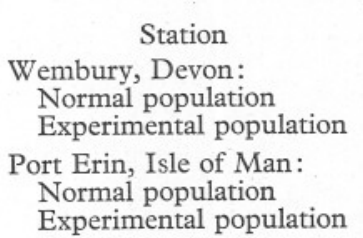

Mortality is extremely high in the early stages of germination and up to the time when the plants are $3 \mathrm{~cm}$. in length. Much of this loss is undoubtedly due to the depredations of molluscs. That this loss may be severe is shown by experiments carried out on the Manx coast by Orton, Jones and Lodge (Lodge, I948). Nearly I 5,000 limpets were removed from a broad strip running through the fucoid zone on the beach at Port St Mary. The zone was only scantily covered by a sparse fucoid population. After removal of the limpets the zone became covered by a dense growth of Fucus which was thick enough to be visible from the air. In the course of 3 years, the limpets have reinvaded the area and the plant population is gradually disappearing. There is now a noticeable scarcity of germlings and the older plants are dying out. A large proportion of the plants reaching the end of their first year are lost during the second year, and only a small proportion survive to the third year. The proportions vary with the physical risks of the environment and depopulation rate rises with exposure. The Devon and Manx areas are compared in Table VIII. 


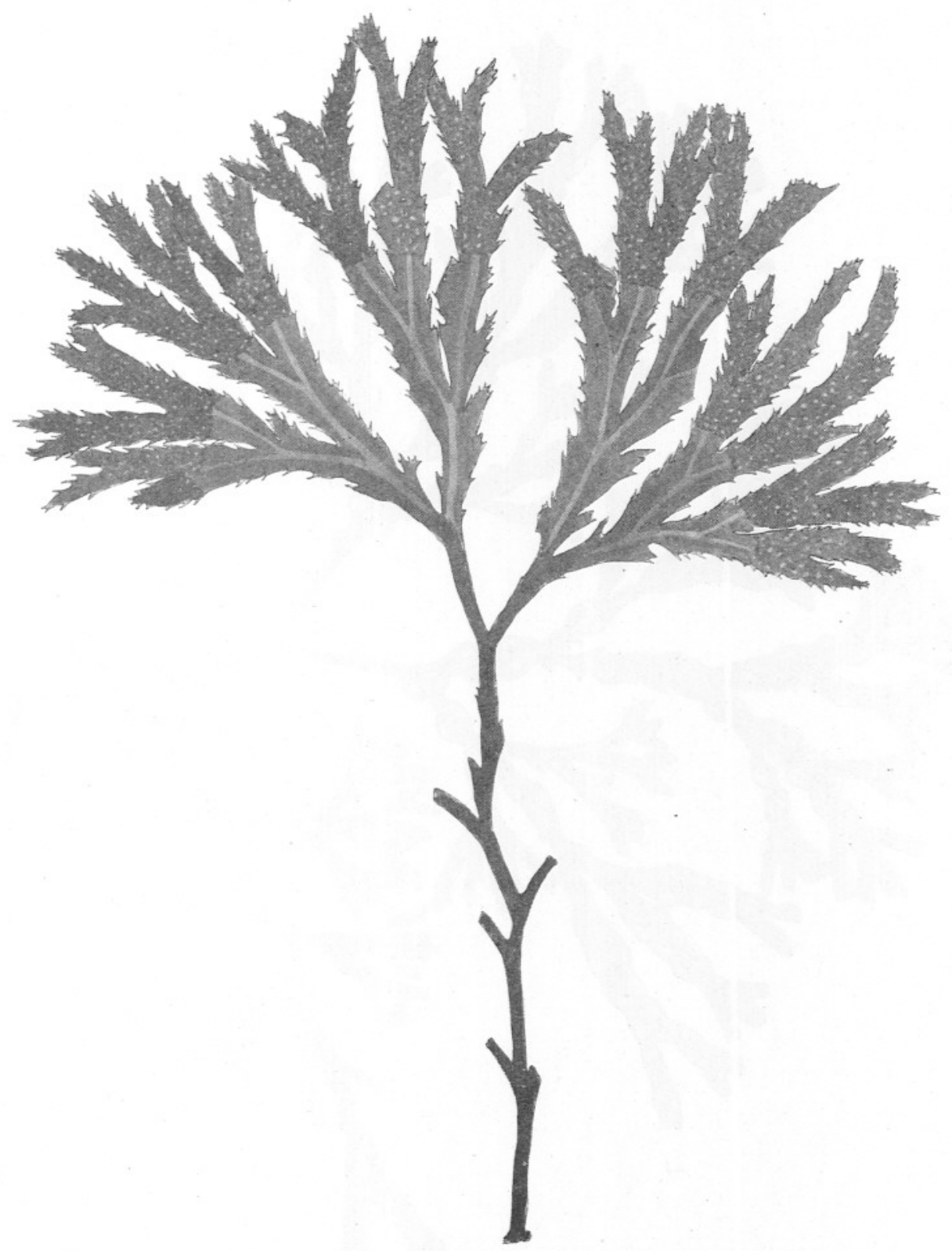

Fig. 26. Plant of Fucus serratus in which copious fruiting has left no vegetative apex for further frond-development. $\times 0.275$. 


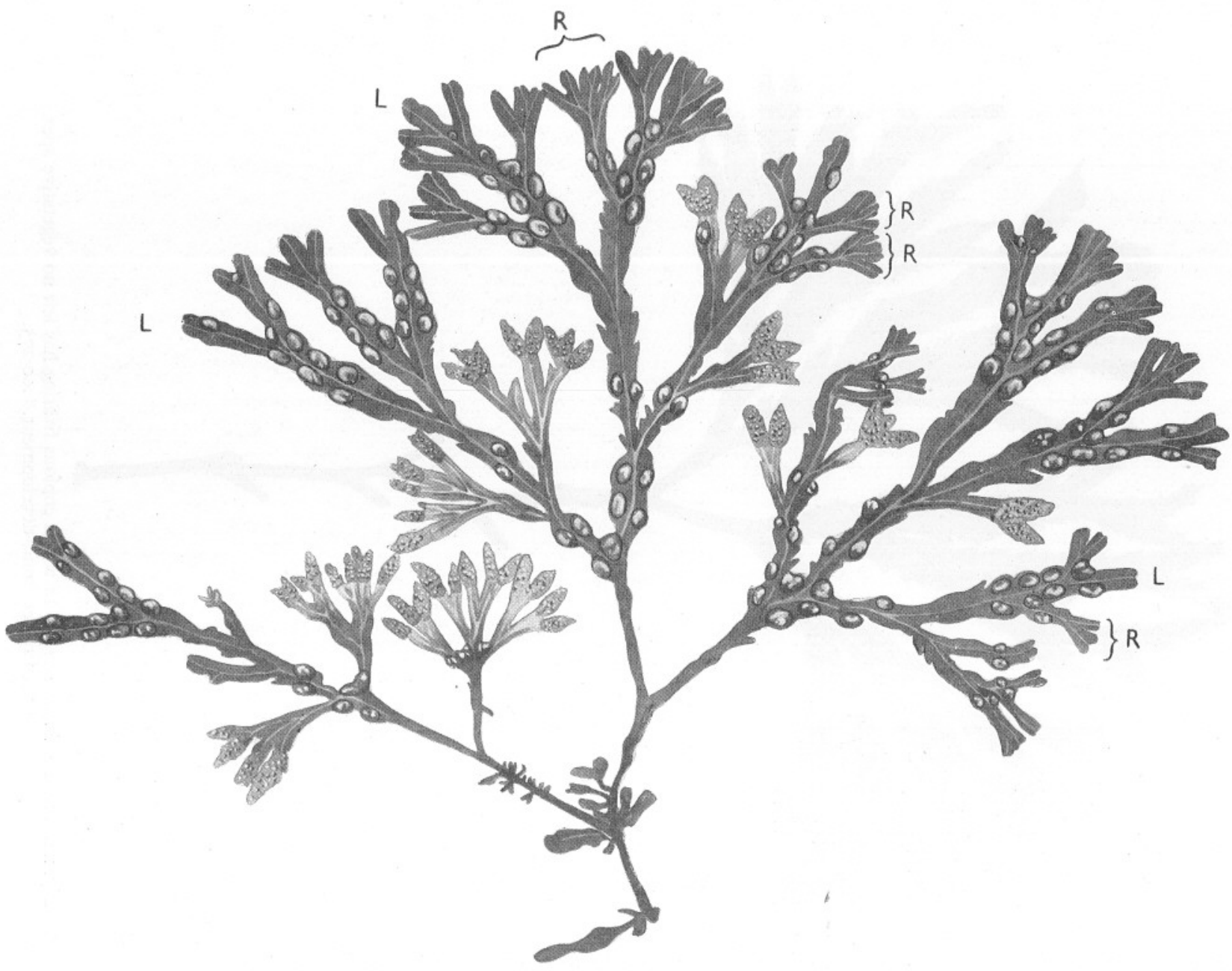

Fig. 27. Defoliation in a plant of Fucus vesiculosus from the Manx coast. The fruiting fans turn yellow and will be ultimately shed. $\times 0.29$. 
In assessing the age-groups in the population, the number of first year plants is taken as $100 \%$, whatever it may be, and the numbers of plants in the other age-groups taken as percentages of it.

It appears that the experimental and normal populations on the Manx station agree very well. On the Devon coast there is some difference between

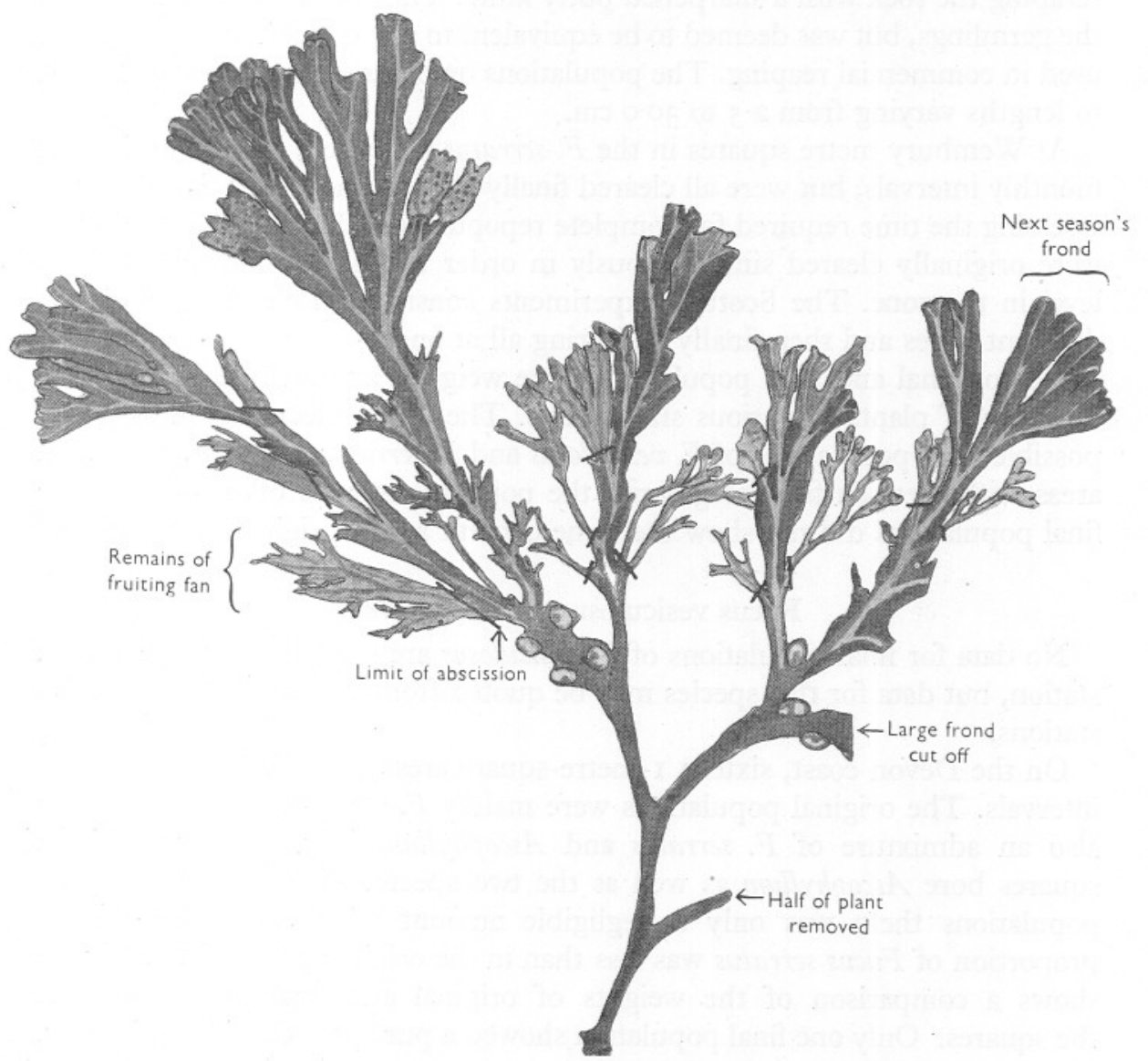

Fig. 28. Plant of Fucus vesiculosus showing a late stage in deterioration of the fruiting fans. The limit of abscission is marked by thick lines across the frond. The vegetative leaders are undergoing dichotomies to form next season's fruiting fans. $\times 0.295$.

the two populations. It can be assumed that the fucoid population on the Manx coast, which is exposed, returns to normal after an interval of 3 years from the original clearance, but 4 years would probably be needed before the population returns to normal on the Devon coast. 


\section{REPOPULATION}

In order to test the effect of reaping, a series of experiments were undertaken in all three areas. Selected plots either in the form of strips or individual squares at various levels were used for experiment. Some were cleared by scraping the rock with a sharpened putty knife. This did not completely clear the germlings, but was deemed to be equivalent to any method which might be used in commercial reaping. The populations on other squares were cut down to lengths varying from $2 \cdot 5$ to $30 \cdot 0 \mathrm{~cm}$.

At Wembury metre squares in the $F$. serratus zone were cleared initially at monthly intervals, but were all cleared finally at the same time, with a view to assessing the time required for complete repopulation. The strips at Port Erin were originally cleared simultaneously in order to find the most productive level in the zone. The Scottish experiments consisted in clearing squares at different times and then finally reclearing all at once.

The original and final populations were weighed and analysed to find the numbers of plants in various size groups. The areas selected bore as far as possible pure populations of $F$. vesiculosus and $F$. serratus, but in the strips on areas with great surface irregularity the populations were often mixed. The final populations did not show the same content as the original populations.

\section{Fucus vesiculosus on cleared areas}

No data for final populations of $F$. vesiculosus are available from the Manx station, but data for this species may be quoted from the Devon and Scottish stations.

On the Devon coast, sixteen I-metre-square areas were cleared at monthly intervals. The original populations were mainly $F$. vesiculosus, but there was also an admixture of F. serratus and Ascophyllum (Fig. 29). Five of the squares bore Ascophyllum as well as the two species of Fucus. In the final populations there was only a negligible amount of Ascophyllum and the proportion of Fucus serratus was less than in the original populations. Fig. 29 shows a comparison of the weights of original and final populations on the squares. Only one final population showed a pure growth of $F$. vesiculosus. The clearance of the squares in sequence gave opportunity for the settlement of eggs from whichever species was in fruit at the time of clearance, but despite the fact that some of the squares were cleared when $F$. serratus was in fruit and $F$. vesiculosus in the almost sterile condition, the final populations, after a lapse of nearly 3 years, consisted mostly of $F$. vesiculosus.

The total original weight on all the squares was $108.6 \mathrm{~kg}$., and the final weight was $107 \cdot \mathrm{I} \mathrm{kg}$., thus giving a net loss of $\mathrm{I} \cdot 5 \mathrm{~kg}$. The period of experiment varied for each square, but the interesting fact emerges that, with the exception of square 16 , the weights in the final populations exceed those in the original populations on those squares which had the shortest experimental periods. 
Square 6 was cleared sixth in the series and was re-cleared later than some of the other squares. It had therefore the longest experimental period of 34 months, yet the final population weighed only $7.4 \mathrm{~kg}$. compared with $9.0 \mathrm{~kg}$. in the

Original clearance

1942

5 Feb. 13 Apr. 16 June 13 Aug. 8 Oct. 5 Dec. 18 Feb. 20 Apr.

7 Mar. 15 May 14 July 10 Sept. 6 Nov. 20 Jan. 24 Mar. 22 May
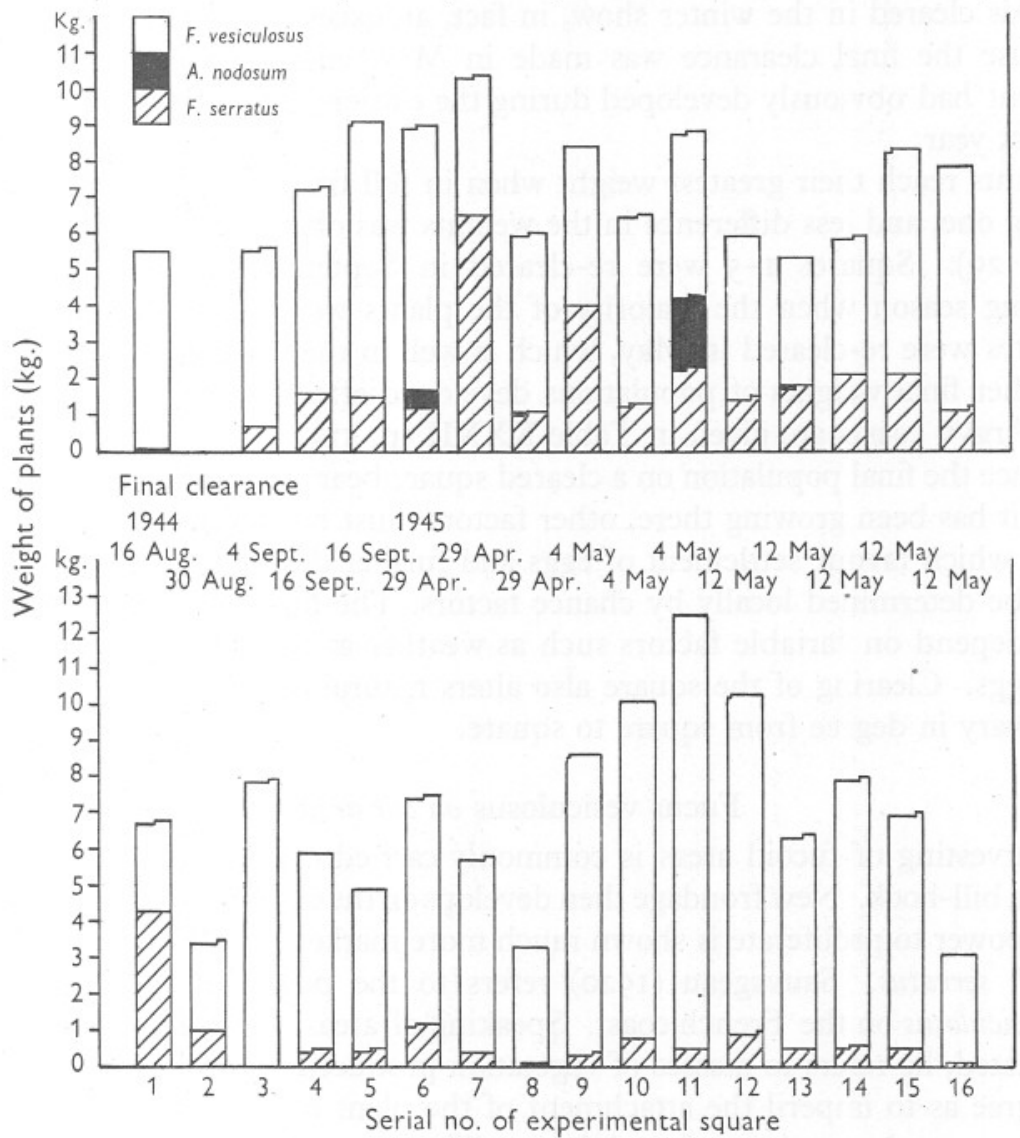

Fig. 29. The repopulation of cleared areas by Fucus vesiculosus on the Devon coast. Original and final weights of plants on sixteen I-metre-square areas at Wembury.

original population. Fig. 30 shows an analysis of the plant populations in size groups at the beginning and end of the experiment. Though the total weight of the final populations is slightly less than that of the original populations, the number of plants in the final populations is much greater than in the original populations (Table I, p. 444). In grouping the plants, $27 \mathrm{~cm}$. was taken as the length of a first-year plant, $55 \mathrm{~cm}$. as the length of a plant at 
the end of its second year, and over $55 \mathrm{~cm}$. for plants older than 2 years. The lengths were based on growth-rate as determined by experiment. The increase in numbers in the final populations is due largely to the much greater number of young plants.

The time of year at which the squares were cleared does not appear to have had much effect. There was no noticeable delay in the return of germlings to squares cleared between October and March. The squares with the shorter periods cleared in the winter show, in fact, an excess of young plants, partly because the final clearance was made in May, and the young plants then present had obviously developed during the earlier part of the fruiting period of that year.

Plants reach their greatest weight when in full fruit. The fruiting period is a long one, and less difference in the weights was obtained than was expected (Fig. 29). Squares I-5 were re-cleared in September at the end of the fruiting season when the majority of the plants were sterile; the remaining squares were re-cleared in May, which is well in the fruiting season.

Other final weights of populations developed after clearance on the Devon and Argyll coasts are given in Table XXXII (p. 513).

Since the final population on a cleared square bears no simple relation to the time it has been growing there, other factors must be considered. The conditions which favour settlement of eggs and further development of sporelings may be determined locally by chance factors. The final population may very well depend on variable factors such as weather at the time of settlement of the eggs. Clearing of the square also alters natural conditions and its effects may vary in degree from square to square.

\section{Fucus vesiculosus on cut areas}

Harvesting of fucoid areas is commonly carried out by cutting the fronds with a bill-hook. New frondage then develops on the cut fronds by proliferation. The power to proliferate is shown much more markedly by $F$. vesiculosus than by $F$. serratus. Sauvageau (1920) refers to the power of proliferation by F. vesiculosus on the French coast. Speaking of areas where Fucus is regularly harvested, he refers to masses of vegetation produced by proliferation to such a degree as to imperil the attachment of the plant to the substratum. In the present experiments it was found that proliferation took place only from fronds which were provided with an apical cell at the time of breakage, that is, that no proliferation will take place on frondage which had produced receptacles. The size of the proliferation-frondage depends on the age of the cut fronds. Proliferation from young frondage will produce frondage of normal size, but, with increasing age of the cut frondage, the proliferated fronds are more and more stunted and may indeed be extremely minute. Proliferated frondage from an old part of the plant has been noted, which was no longer than $2 \mathrm{~cm}$. and bore minute receptacles less than $0.3 \mathrm{~cm}$. long. It is obvious that in 


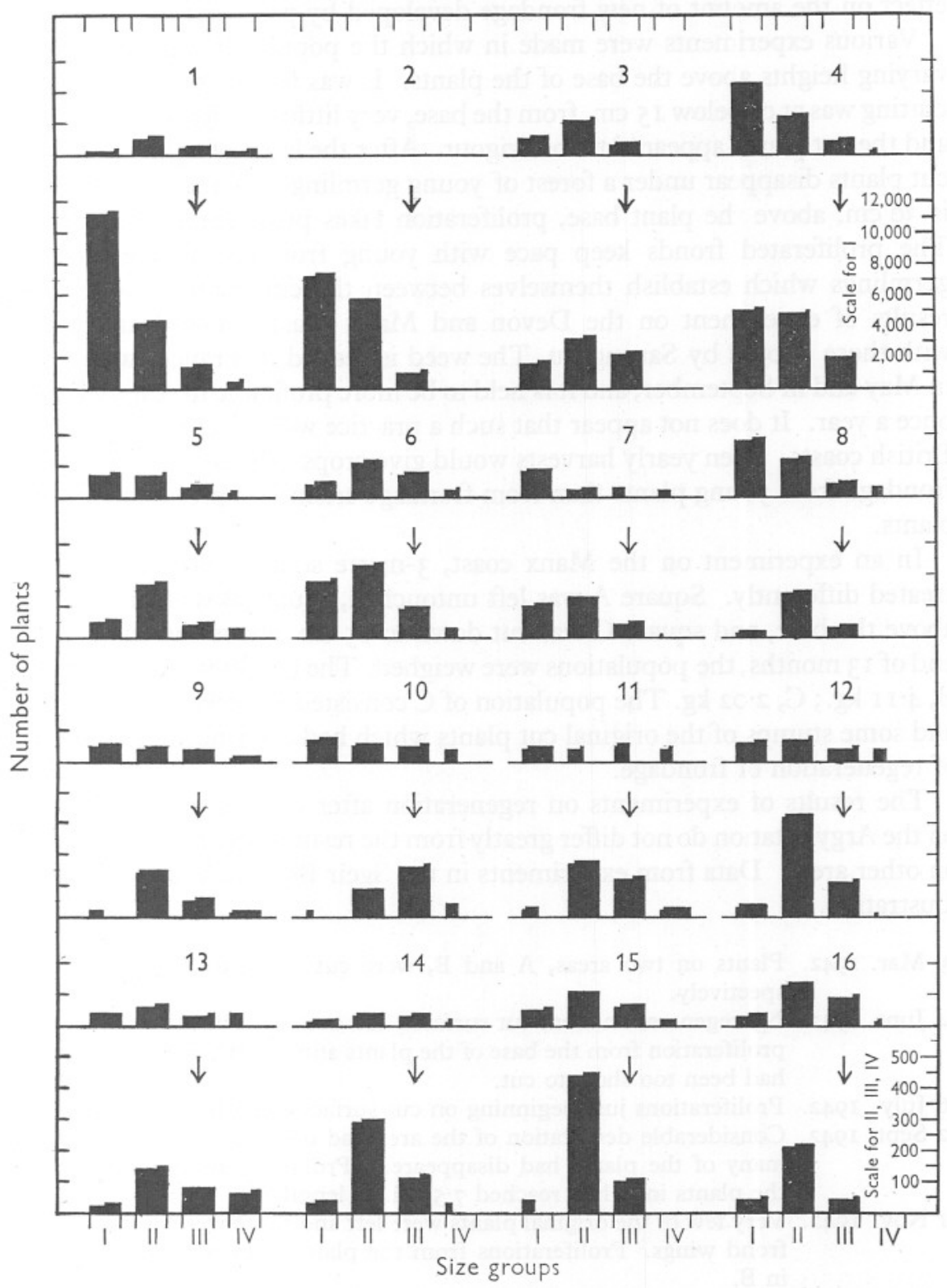

Fig. 30. The repopulation of cleared areas by Fucus vesiculosus on the Devon coast. Original and final numbers of plants in size-groups on sixteen I-metre-square areas at Wembury. Size-groups as follows: I, under $10 \mathrm{~cm}$. in length; II, IO-27 cm.; III, 27$55 \mathrm{~cm}$.; IV, 55 and over. Scale for group I (top right corner) is reduced by a factor of 20. 
reaping by cutting, the height of the cut above the base of the plant will have an effect on the amount of new frondage developed by proliferation.

Various experiments were made in which the population was cut down to varying heights above the base of the plants. It was found that, if the level of cutting was at or below $15 \mathrm{~cm}$. from the base, very little proliferation took place, and the cut plants appeared to lose vigour. After the lapse of a year or two, the cut plants disappear under a forest of young germlings. If the level of cutting is $30 \mathrm{~cm}$. above the plant base, proliferation takes place readily and rapidly. The proliferated fronds keep pace with young frondage arising from the germlings which establish themselves between the cut plants. None of the results of experiment on the Devon and Manx coasts showed any parallel with those quoted by Sauvageau. The weed is reaped in France twice a year, in May and in September, and it is held to be more profitable to reap twice than once a year. It does not appear that such a practice would be profitable on the British coasts. Even yearly harvests would give crops consisting of much more frondage from young plants than from frondage arising by proliferation of cut plants.

In an experiment on the Manx coast, 3 -metre squares side by side were treated differently. Square A was left untouched, square B was cut to $30 \mathrm{~cm}$. above the base, and square $\mathrm{C}$ was cut down to $15 \mathrm{~cm}$. above the base. At the end of $I_{3}$ months, the populations were weighed. The results were: $\mathrm{A}, 4.76 \mathrm{~kg}$.; $\mathrm{B}, 4 . \mathrm{II} \mathrm{kg}$.; C, $2.02 \mathrm{~kg}$. The population of C consisted entirely of young plants and some stumps of the original cut plants which had done nothing in the way of regeneration of frondage.

The results of experiments on regeneration after cutting for $F$. vesiculosus on the Argyll station do not differ greatly from the results of similar experiments on other areas. Data from experiments in the Sgeir Bhuidhe area will serve as illustration.

I9 Mar. 1942. Plants on two areas, A and B, were cut down to 8 and $15 \mathrm{~cm}$. respectively.

4 June 1942. No regeneration from cut surfaces had occurred, but there was a little proliferation from the base of the plants and growth from fronds which had been too short to cut.

I6 July 1942. Proliferations just beginning on cut surfaces of plants on A and B.

I2 Sept. I942. Considerable devastation of the area had occurred in the interval and many of the plants had disappeared. Proliferations from the base of the plants in $\mathrm{B}$ had reached $7.5 \mathrm{~cm}$. in length.

II Nov. 1942. Very few of the original plants were left and those were denuded of the frond wings. Proliferations from the plant bases had reached $15 \mathrm{~cm}$. in $\mathrm{B}$.

6 Feb. 1943. More deterioration had occurred in the cut population and the stumps were almost hidden under a growth of new plants.

From this point on progressive deterioration followed, and at last there were none of the original cut plants left. It is obvious that no profit would result by 
cutting the population at levels less than $30 \mathrm{~cm}$. above ground. In any case the great bulk of the returning population is derived from the upgrowth of new plants.

\section{Fucus serratus on cleared areas}

A strip, I m. wide, running through the entire belt of $F$. serratus was cleared at Port Erin in July I94I. In its upper levels the population of the strip was mixed F. serratus (dominant), Ascophyllum and Fucus vesiculosus. The middle section was pure $F$. serratus and the lower levels ran into the top of the Laminaria digitata zone. That part of the strip which carried a pure population of Fucus serratus was $9 \mathrm{~m}$. long. The two uppermost squares on the strip were covered by boulders after a storm, but the rest of the strip escaped much interference.

The total weight of the plant population was initially $170 \mathrm{~kg}$, , of which $47 \mathrm{~kg}$. was due to Ascophyllum. The final weight of the population was $92 \mathrm{~kg}$., representing a total loss in weight of $78 \mathrm{~kg}$. This deficit is in part explained by the fact that Ascophyllum did not regenerate itself on the cleared area during the period of the experiment. Sporelings appeared in small numbers and reached a length of a few $\mathrm{cm}$., but inevitably disappeared again. Even at this date, 8 years after the original clearance, there is still no sign of the establishment of an Ascophyllum population. There are on an average 20 sporelings of Ascophyllum per $\mathrm{m}^{2}$., the longest of which is only $13.5 \mathrm{~cm}$. Fig. $3 \mathrm{I}$ and Table XXXIV (p. 5I4) show the analyses of the weights and numbers of the final and original populations. A summary of the proportions of the component algae is shown below:

$\begin{array}{lcc} & \begin{array}{c}\text { Original population } \\ \text { (kg.) }\end{array} & \begin{array}{c}\text { Final population } \\ \text { (kg.) }\end{array} \\ \text { Total weight } & \mathrm{I} 70 & 92 \\ F . \text { vesiculosus } & \mathrm{I} & 4 \\ \text { F. serratus } & 87 & 7 \mathrm{I} \\ \text { Ascophyllum } & 47 & 0 \\ \text { Laminaria } & 32 & \mathrm{I} 7\end{array}$

The Fucus population might have been expected to gain advantage by the improvement in lighting of the strip by the removal of the Ascophyllum; there is an increase of $3 \mathrm{~kg}$. in the weight of Fucus vesiculosus when its competitor Ascophyllum was removed and failed to return, but this slight advantage is balanced by the decreased weight of Fucus serratus in the final population. There is no permanent population of Laminaria at this level on the shore, as the young plants are frequently removed and replaced. Rough weather caused considerable fluctation in the amount of Laminaria above L.W.N.T. L. digitata, $90 \mathrm{~cm}$. long, was recorded at interim observations, but the long plants had all disappeared when the strip was finally cleared in April I944. The data from a repopulation experiment from Wembury involving nineteen I-metre squares, F.S.H. I-3 and F.S.L. I-I6, may be used to illustrate recolonization on the 
Devon coast. Figs. 32 and 33 give a comparison of weights in the original and final populations and analyses of the numbers of plants in various size groups.

A summary of the data is given below:

$\begin{array}{lcc} & \text { Original population } & \text { Final population } \\ & \text { (kg.) } & \text { (kg.) } \\ \text { Total weight } & 137.7 & 133.0 \\ \text { F. serratus } & 137.4 & 131.7 \\ \text { F. vesiculosus } & 0.3 & 0.5 \\ \text { Laminaria } & - & 0.8\end{array}$

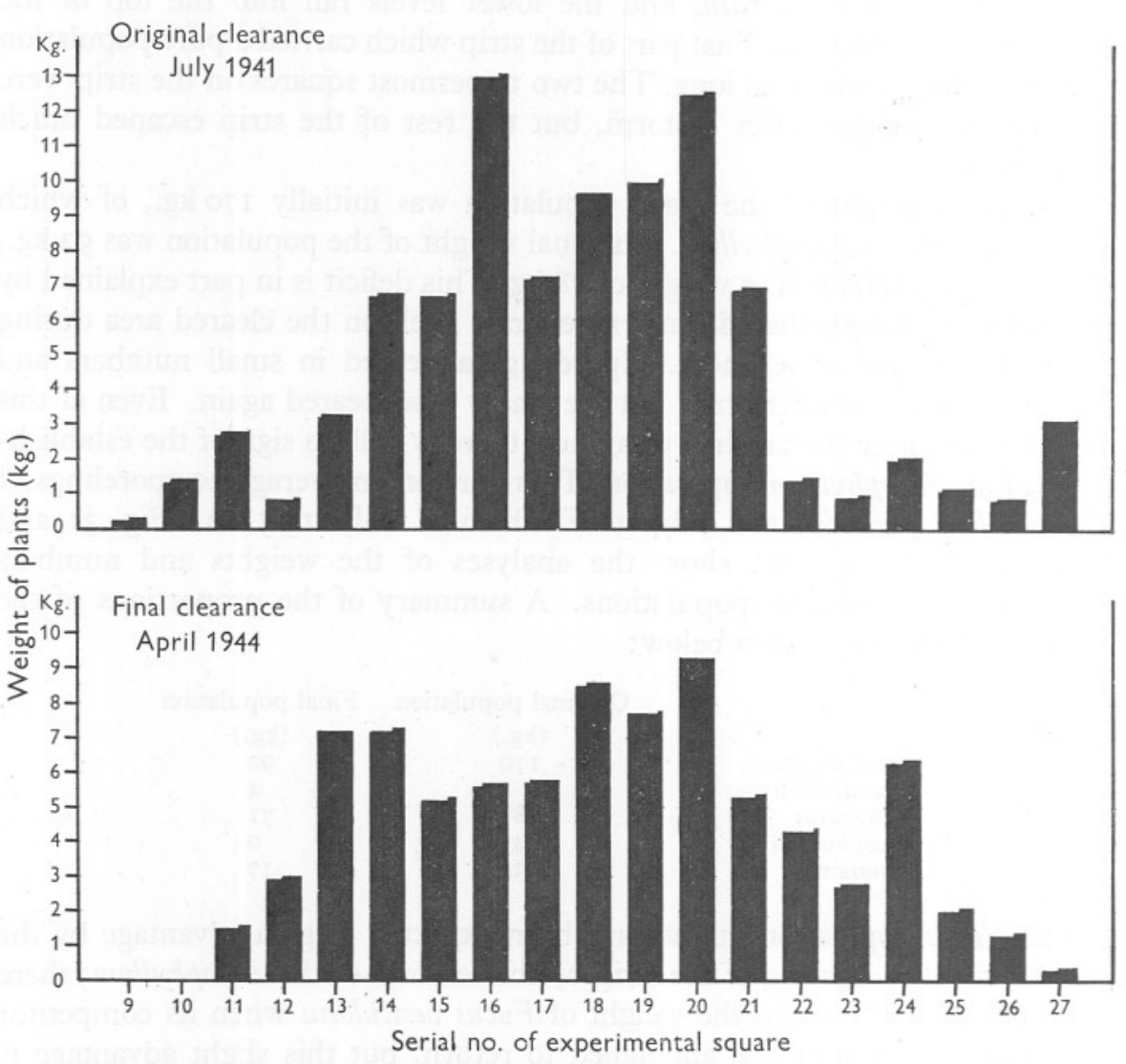

Fig. 3r. The repopulation of cleared areas by Fucus serratus on the Manx coast. Original and final weights of plants on nineteen I-metre-square areas at Port Erin.

The Devon population on the Fucus serratus squares was much more nearly a pure $F$. serratus population than that on the Port Erin station. There was no Ascophyllum present, and the final weight was only $4.7 \mathrm{~kg}$. short of the original weight.

Other final weights of populations, developed after clearance on the Devon and Argyll coasts, are given in Table XXXII in the Appendix (p. 513). 
Fucus serratus on cut areas

The results of experiments in which the vegetation was truncated do not differ greatly from those with $F$. vesiculosus. As with the latter species, the areas of $F$. serratus showed normal growth of apices which were too short to be cut. The removal of a large percentage of the apical cells by cutting seems to be detrimental to the tone of the plant. Denudation of the wings of the fronds

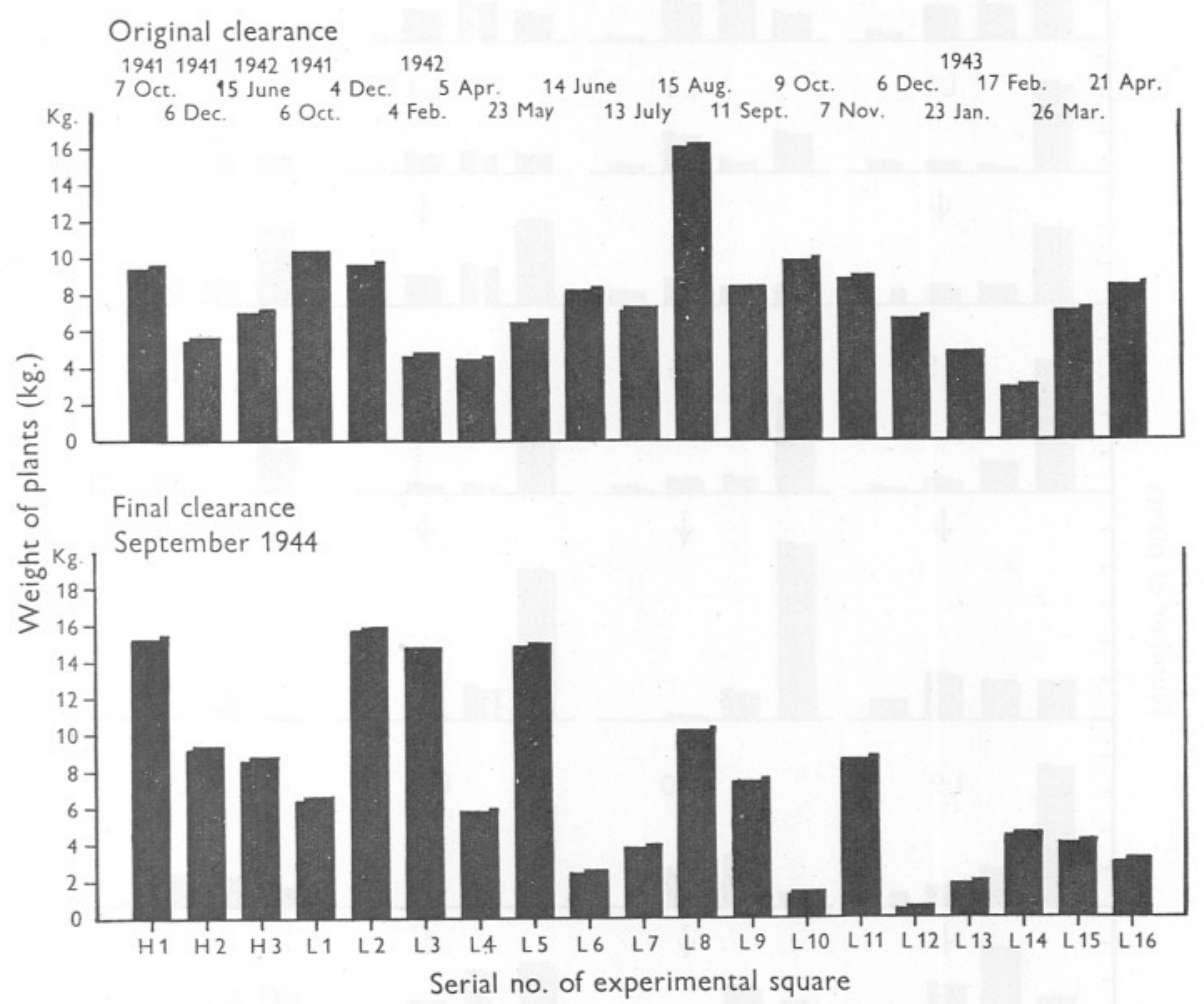

Fig. 32. The repopulation of cleared areas by Fucus serratus on the Devon coast. Original and final weights of plants on nineteen I-metre-square areas at Wembury.

is marked, and the plant is readily infected by epiphytic algae. The growth of the uncut shoots keeps pace with the elongation of young plants which develop on the experimental plots if the original truncation was made at a height of $30 \mathrm{~cm}$. from the base of the plant. When the level of cutting was $15 \mathrm{~cm}$. from the base, the rate of elongation of uncut fronds was less than that of young plants. The explanation of the difference lies in the age of the cut frondage. Cutting at a level of $15 \mathrm{~cm}$. leaves only old portions of large plants. These lower parts of the plant have much less vigour of growth than the younger distal frondage. On cut fronds of $F$. serratus it is only rare that proliferations 


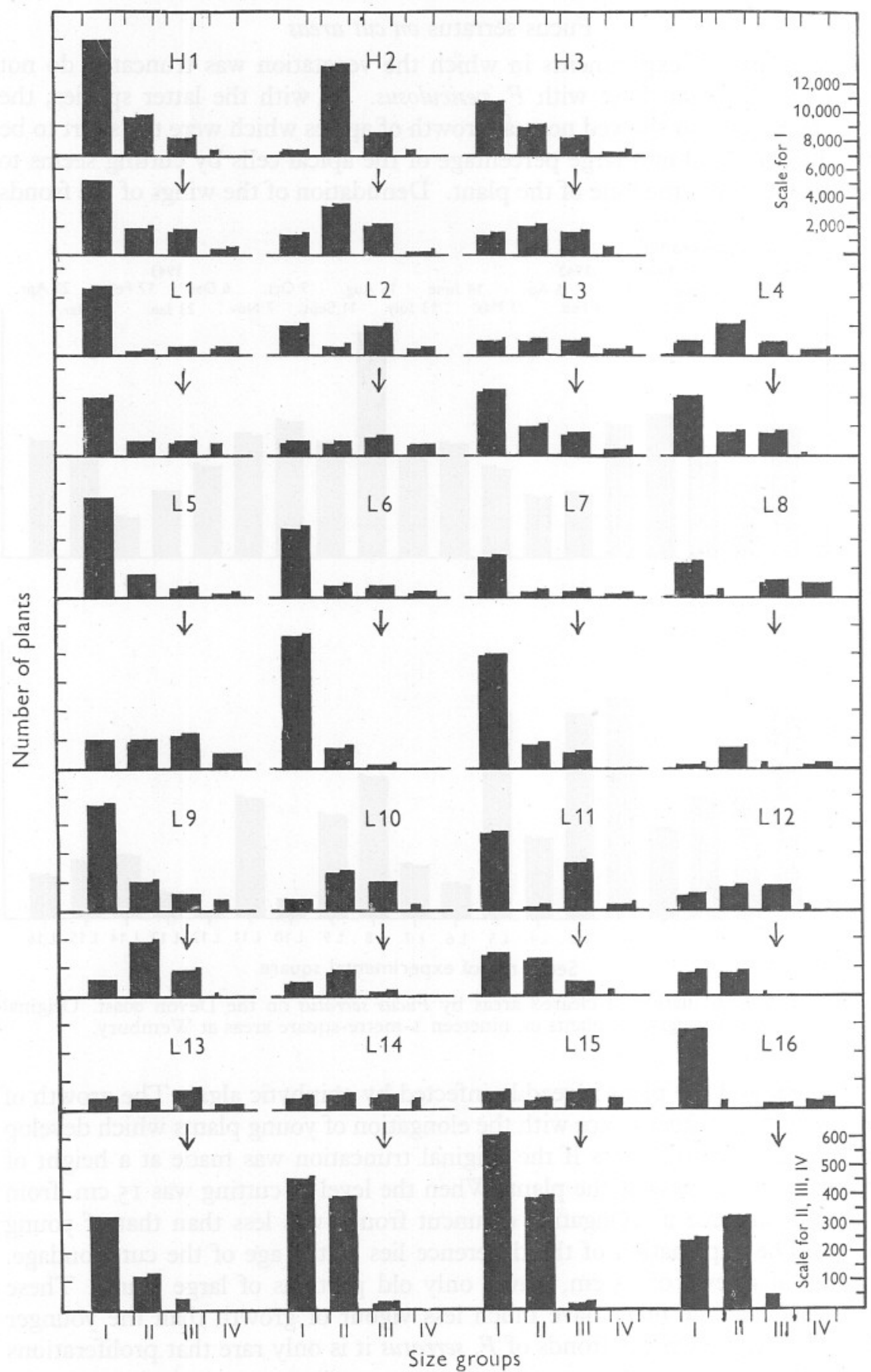

Fig. 33. The repopulation of cleared areas by Fucus serratus on the Devon coast. Original and final numbers of plants in size-groups on nineteen I-metre-square areas at Wembury. Size-groups as follows: I, under Io cm. in length; II, IO-27 cm.; III, $27-55 \mathrm{~cm}$.; IV, $55 \mathrm{~cm}$. and over. Scale for Group I (top right corner) is reduced by a factor of 20 . 
occur on the bare midribs or on the cut surfaces of the fronds. In this respect the species differs from $F$. vesiculosus which proliferates readily.

From such experiments in cutting which have been done in this investigation, it would appear that reaping every 2 years would give the best results. There is no advantage in waiting for plants of larger growth because the depletion rate for large plants is too high to permit of any advantage. A good uniform population of young plants develops in one year, but they are very light; the second year population has a greatly increased bulk, but the depletion rate rises. New populations grow very rapidly on cleared areas, and it does not appear that cutting off the tops of the plants rather than removing them bodily would give any advantage, especially with $F$. serratus.

From records which are available it seems that the cutting of fucoids is usually annual, and on the coast of France weed is reaped twice in the year. Whether that is done because there is a better total yield from areas treated in this way or because the weed is needed every year is not stated. The reaping referred to in the literature is probably a mixed crop of Ascophyllum and the two species of Fucus. No mention is made of how much of the area is reaped at one time. It would appear from the results of the present experiments that the best yield might be gained by reaping alternate areas at intervals of I8 months to 2 years.

Sauvageau (1920) makes reference to the view held by the French weed-cutters that weed reaped in the spring is of greater value as a fertilizer than weed reaped in the autumn. There is no reference to which component of the weed is meant in this statement. In the spring, both $F$. vesiculosus and Ascophyllum would be fruiting and might be considered to be in a state of greatest vigour, but this could not apply to Fucus serratus. Further research is obviously needed into the seasonal change of chemical content of the weed at various ages, and especially changes related to the onset and development of the reproductive stages.

\section{CONCLUSION}

Concentration on details of seasonal behaviour of two species of marine algae over an extended period of time has revealed some facts which were not known before. The interest of the records lies not only in their novelty, but also in the speculation to which they may give rise.

One is familiar with the alternation of reproductive and vegetative phases in land plants, but with the two species of Fucus under discussion, the seasonal rhythms stand opposed to one another; the vegetative season of one coincides with the reproductive season of the other species. The actual physical components of the environment which control the onset of reproduction are as yet unascertained.

It is also somewhat surprising to find that the familiar monopodial and sympodial branching of land plants have their counterparts in the sea; and 
that something very like an axial gradient is shown by the basipetally increasing latency of apices in F. serratus.

The degree of apical control on subperipheral frondage is also well marked. Apical controls are exerted on the stature of proliferations from various levels in the plant body, and on the arrest of necrosis of tissue following reproduction, at a point where one arm of a dichotomy is still provided with an apical cell. In the development of receptacles an antithesis between vegetative elongation and reproduction is shown by the fact that in $F$ : vesiculosus gametangia are not laid down in the receptacle until the apical cell has ceased to function and the apical groove has flattened out.

It is interesting to reflect that in the course of a long evolution in the sea, such relatively 'simple' marine plants as these two species of Fucus have developed growth rhythms, habits of branching, controlled defoliation after fruiting, and apical control of remote parts of subtending tissue, in a degree comparable to that shown by land plants with an entirely different history.

\section{SUMMARY}

A certain variation in level of the fucoid zone with latitude is demonstrated. The belt of Fucus vesiculosus and F. serratus lies lower on the Devon coast than on either the Manx or the Argyll coast.

The conditions for the optimum germination of fertilized eggs are dissimilar to those for maximum rate of frond-extension.

Normal growth-rates have been established for both species for the first 3 years of life. In $F$. vesiculosus the average rate of elongation per week is $0.48 \mathrm{~cm}$. on the Devon coast, $0.45 \mathrm{~cm}$. on the Manx coast and $0.68 \mathrm{~cm}$. on the Argyll coast. In F. serratus the average rate of elongation per week is $0.49 \mathrm{~cm}$. on the Devon coast, $0.68 \mathrm{~cm}$. on the Manx coast and $0.85 \mathrm{~cm}$. on the Argyll coast. The rate of growth is shown to vary with the conditions of the environment. Shelter from rough water tends to enhance growth-rate, and there is an indication that greater stature is achieved by the plants from the Argyll station than from either of the other stations.

Growth-rate in the second and subsequent years shows a rhythm induced by alternating emphasis on receptacle-formation and frond-extension.

The rate of forking is shown to be encouraged by conditions of exposure, but is unaccountably greater on the Devon coast for both species.

The existence of a morphological rhythm showing latent superiority of growth-potential by one arm of a dichotomy, alternating from side to side of the thallus at each successive dichotomy has been demonstrated.

Continued frond-extension in F. serratus has been shown to proceed by a kind of relay-system. Distal frondage becomes largely receptacular and further elongation of the plant is brought about by the renewed activity of subperipheral apices. 
Frond-extension in $F$. vesiculosus is due to continued elongation of primary and secondary leaders which may produce reproductive fans in pseudolateral positions but always maintain one peripheral leader.

The range of variation shown by $F$. vesiculosus in number and position of vesicles is illustrated and its significance discussed.

The sequence of stages in receptacle-formation is defined. The incidence of fruiting is compared for the two species and for various stations. Fucus serratus is shown to have a wider range of fruiting time in relation to geographical locality.

The excision of depleted receptacular frondage is achieved by necrosis of tissue, working basipetally until stopped at a dichotomy, one arm of which is still under the control of a functional apex, however distant.

Depopulation brought about by accidental removal of plants in rough weather is shown to be considerable.

Repopulation in relation to the time factor is discussed on data from the three stations.

\section{REFERENCES}

Colman, J., I933. The nature of the intertidal zonation of plants and animals. Fourn. Mar. Biol. Assoc., Vol. xvill, pp. 435-76.

Cotton, A. D., I9I2. Marine Algae. Clare Island Survey, Pt. I5. Proc. Roy. Irish Acad., Vol. 3I, pp. I-I78.

Evans, R. G., I947. The intertidal ecology of selected localities in the Plymouth neighbourhood. Fourn. Mar. Biol. Assoc., Vol. xxviI, pp. I73-218.

GaIL, F. W., I9I8. Some experiments with Fucus to determine the factors controlling its vertical distribution. Puget Sound Mar. Sta. Publ., Vol. 2, pp. 139-5I.

GARD, M., I916. Le Fucus ceranoides et les hybrides dans le genre Fucus. Bordeaux.

GisLÉn, T., I930. Epibioses of the Gullmar Fjord, etc. II. Kristinebergs Zool. Stat., I877-I927 (Skriftserie utg. K. Svensk. Vet. Akad.), Uppsala, No. 4, 380 pp.

Hariot, P., 1909. Sur la croissance des Fucus. C.R. Acad. Sci., Paris, T. I49, pp. $352-4$.

Hatton, H., I932. Quelques observations sur le repeuplement en Fucus vesiculosus des surfaces rocheuses dénudées. Bull. Lab. Marit. Saint-Servan, T. 9, pp. I-6.

Lemorne, P., I9r3. Quelques expériences sur la croissance des Algues marines à Roscoff. Bull. Inst. Océanogr. Monaco, No. 277, pp. I-I9.

Lodge, S. M., I948. Algal growth in the absence of Patella on an experimental strip of foreshore, Port St Mary, Isle of Man. Proc. and Trans. Liverpool Biol. Soc., Vol. 56 , pp. $78-83$.

Lund, S., 1936. On the production of matter and the growth in some benthic plants. Rep. Danish Biol. Stat., Vol. 4I, pp. 37-52. Copenhagen.

NienburG, W., 1930. Die Algenbesiedelung des Felsstrandes und der Klippen von Helgoland. II. Die Algen. Wiss. Meeresunters., Helgoland, N.F., Bd. I5, No. I9, pp. I-I 5 .

Printz, H., I926. Die Algenvegetation des Trondhjemsfjorden. Skr. Norske VidenskAkad., Mat.-Nat. K1., No. 5, pp. I-273.

ReEs, T. K., I932. A note on the longevity of certain species of the Fucaceae. Ann. Bot., Vol. 46, pp. 1063-4.

SAuvageau, C., I920. Utilisation des algues marines. 394 pp. Paris. 


\section{APPENDIX}

Table IX. Growth-Rate by Marked Plants of FucUs vesiculosus AT WEMBURY

\begin{tabular}{|c|c|c|c|c|c|}
\hline \multirow[b]{2}{*}{ Plant no. } & \multicolumn{4}{|c|}{ Square I4 on strip } & \multirow[b]{2}{*}{$\begin{array}{l}\text { Growth-rate } \\
\text { per week } \\
\text { (cm.) }\end{array}$} \\
\hline & $\begin{array}{l}\text { Duration } \\
\text { of exp. } \\
\text { (days) }\end{array}$ & $\begin{array}{l}\text { Increase } \\
\text { in length } \\
(\mathrm{cm} .)\end{array}$ & $\begin{array}{l}\text { Increase } \\
\text { in no. of } \\
\text { dichotomies }\end{array}$ & $\begin{array}{l}\text { Increase in } \\
\text { no. of tips }\end{array}$ & \\
\hline A I & 287 & $26 \cdot 0$ & 7 & $5 \mathrm{I} 7$ & 0.69 \\
\hline 2 & 364 & $36 \cdot 0$ & 9 & 628 & $0.7 \mathrm{I}$ \\
\hline 3 & 512 & $27 \cdot 0$ & 9 & 218 & 0.36 \\
\hline 4 & 377 & $40 \cdot 0$ & 12 & I76I & 0.74 \\
\hline 5 & 338 & I9.0 & 9 & 625 & 0.36 \\
\hline 6 & I57 & 19.5 & 5 & - & 0.87 \\
\hline 7 & I86 & 23.5 & 8 & 521 & 0.88 \\
\hline $\mathrm{B}$ I & 32 & 4.5 & 2 & - & $I \cdot 0$ \\
\hline 2 & 32 & 3.5 & I & - & 0.75 \\
\hline 3 & 58 & $6 \cdot 5$ & I & - & 0.78 \\
\hline 4 & 383 & $27 \cdot 0$ & Io & - & 0.49 \\
\hline 5 & 58 & 4.5 & 4 & - & 0.52 \\
\hline 6 & 165 & 8.5 & 2 & - & $0.3 \mathrm{I}$ \\
\hline $\mathrm{C}_{\mathrm{I}}$ & 32 & $7 \cdot 0$ & 0 & - & $\mathrm{I} \cdot 55$ \\
\hline 2 & I9I & I3.0 & 5 & - & .0 .46 \\
\hline 3 & 58 & 9.5 & 2 & - & $I \cdot I 4$ \\
\hline 4 & $22 I$ & $7 \cdot 0$ & 3 & - & 0.22 \\
\hline 5 & 235 & $6 \cdot 0$ & 6 & - & 0.17 \\
\hline 6 & I34 & $8 \cdot 0$ & I & - & $0.4 \mathrm{I}$ \\
\hline 7 & 105 & 3.5 & 2 & - & 0.23 \\
\hline 8 & I93 & II $\cdot 5$ & 5 & - & 0.40 \\
\hline
\end{tabular}

Average elongation-rate, $0.62 \mathrm{~cm}$. per week.

Table X. Growth-rate by Marked Plants of Fucus vesiculosus AT WEMBURY

\begin{tabular}{|c|c|c|c|c|}
\hline \multirow[b]{2}{*}{ Plant no. } & \multicolumn{3}{|c|}{ Square $16 \mathrm{~A}$ on strip } & \multirow[b]{2}{*}{$\begin{array}{l}\text { Growth-rate } \\
\text { per week } \\
(\mathrm{cm} .)\end{array}$} \\
\hline & $\begin{array}{l}\text { Duration } \\
\text { of exp. } \\
\text { (days) }\end{array}$ & $\begin{array}{c}\text { Increase } \\
\text { in length } \\
(\mathrm{cm} .)\end{array}$ & $\begin{array}{l}\text { Increase } \\
\text { in no. of } \\
\text { dichotomies }\end{array}$ & \\
\hline I & 810 & $34 \cdot 0$ & II & 0.29 \\
\hline 2 & 249 & I9.0 & 7 & 0.53 \\
\hline 3 & 633 & $34 \cdot 0$ & I7 & 0.37 \\
\hline 4 & 664 & $33 \cdot 0$ & I3 & 0.34 \\
\hline 5 & 810 & $56 \cdot 5$ & $2 I$ & 0.48 \\
\hline 6 & 563 & $40 \cdot 0$ & IO & 0.49 \\
\hline 7 & $37 \mathrm{I}$ & $2 \mathrm{I} \cdot 5$ & 4 & 0.40 \\
\hline
\end{tabular}

Average elongation rate, $0.4 \mathrm{I} \mathrm{cm}$. per week. 
Table Xi. Growth-Rate by Marked Plants of Fucus vesiculosus AT WEMBURY

Fucus vesiculosus, areas I and 2

\begin{tabular}{|c|c|c|c|c|c|c|c|}
\hline \multirow{3}{*}{$\begin{array}{l}\text { Plant no. } \\
\text { Area I: } 725\end{array}$} & \multicolumn{3}{|c|}{ Length (cm.) } & \multicolumn{2}{|c|}{$\begin{array}{c}\text { No. of } \\
\text { dichotomies }\end{array}$} & \multirow{2}{*}{$\begin{array}{l}\text { Duration } \\
\text { of exp. } \\
\text { in days }\end{array}$} & \multirow{2}{*}{$\begin{array}{c}\text { Growth- } \\
\text { rate per } \\
\text { week } \\
(\mathrm{cm} .)\end{array}$} \\
\hline & Initial & Final & Increase & Initial & Final & & \\
\hline & $34 \cdot 0$ & $\begin{array}{l}3 \mathrm{r} \cdot \mathrm{OF} \text {. } \\
48 \cdot \mathrm{M} \text {. }\end{array}$ & $\begin{array}{r}-3.0 \\
14.0\end{array}$ & $\begin{array}{l}9 \\
9\end{array}$ & $\begin{array}{r}9 \\
\end{array}$ & $93 \mathrm{I}$ & - \\
\hline 727 & $36 \cdot 0$ & 54.0 & 18.0 & $\begin{array}{l}9 \\
9\end{array}$ & $\begin{array}{l}12 \\
26\end{array}$ & $\begin{array}{l}46 \mathrm{I} \\
688\end{array}$ & $\begin{array}{l}0.21 \\
0.18\end{array}$ \\
\hline 284 & $9 \cdot 0$ & $35 \cdot 0$ & $26 \cdot 0$ & 2 & I3 & 654 & 0.26 \\
\hline 705 & $46 \cdot 0$ & $7 \mathrm{I} \cdot 0$ & $15 \cdot 0$ & I8 & 24 & 546 & 0.32 \\
\hline 710 & $22 \cdot 0$ & $35 \cdot 5$ & I3.5 & 6 & II & 490 & 0.19 \\
\hline 726 & $16 \cdot 0$ & $27 \cdot 5$ & II $\cdot 5$ & 5 & 8 & 385 & 0.20 \\
\hline 740 & $26 \cdot 0$ & $55^{\circ} 0$ & $29 \cdot 0$ & 6 & 20 & 654 & 0.31 \\
\hline 707 & $44 \cdot 0$ & $5 \mathrm{I} \cdot 0$ & $7 \cdot 0$ & I6 & I5 & 210 & 0.23 \\
\hline 708 & $24 \cdot 0$ & $3 \mathrm{I} \cdot 5$ & $7 \cdot 5$ & IO & I8 & 325 & 0.16 \\
\hline 720 & $45^{\circ} 0$ & $56 \cdot 0$ & II $\cdot 0$ & I 7 & 23 & 210 & 0.36 \\
\hline 724 & $22 \cdot 0$ & $32 \cdot 5$ & $10 \cdot 0$ & 5 & 9 & 325 & 0.21 \\
\hline 728 & $43 \cdot 0$ & 62.5 & I9.5 & II & $2 \mathrm{I}$ & 268 & 0.50 \\
\hline 742 & 29.0 & $33 \cdot 0$ & 4.0 & 5 & IO & 325 & 0.08 \\
\hline 743 & $48 \cdot 0$ & $72 \cdot 0$ & $24 \cdot 0$ & II & 24 & 414 & 0.40 \\
\hline 744 & $38 \cdot 0$ & $55^{\circ} 0$ & I7 70 & I4 & 20 & 325 & 0.36 \\
\hline 750 & $44^{\circ} 0$ & 59.5 & I5.5 & I8 & 25 & 268 & 0.40 \\
\hline 150 & $18 \cdot 0$ & 20.5 & 2.5 & 3 & 4 & 210 & 0.08 \\
\hline I5I & $14 \cdot 5$ & $\mathrm{I} 7 \cdot 8$ & $3 \cdot 3$ & I & I & I 82 & 0.12 \\
\hline Area 2: I & $82 \cdot 0$ & $96 \cdot 0$ & $\mathrm{I} 4 \cdot \mathrm{O}$ & 32 & 37 & 309 & 0.29 \\
\hline 8 & $7 \mathrm{I} \cdot 0$ & $8 \mathrm{I} \cdot 0$ & 10.0 & $2 I$ & 24 & 183 & 0.38 \\
\hline II & $76 \cdot 5$ & $79 \cdot 0$ & 2.5 & 27 & 29 & 94 & 0.17 \\
\hline I6 & $67 \cdot 0$ & $70 \cdot 0$ & $3 \cdot 0$ & 24 & 24 & 94 & 0.22 \\
\hline I7 & $7 \mathrm{I} \cdot 5$ & 85.0 & I3.5 & I8 & $2 \mathrm{I}$ & 183 & 0.51 \\
\hline 72 & 13.0 & $28 \cdot 5$ & I5. 5 & 3 & 8 & 324 & 0.33 \\
\hline 82 & 25.0 & $46 \cdot 0$ & $2 \mathrm{I} \cdot 0$ & 6 & I6 & 385 & 0.38 \\
\hline 86 & $46 \cdot 0$ & $54 \cdot 0$ & $8 \cdot 5$ & I2 & I 7 & 309 & 0.17 \\
\hline 88 & 26.5 & $51 \cdot 0$ & $24 \cdot 5$ & 7 & I5 & 324 & 0.52 \\
\hline 4 & $49 \cdot 5$ & $87^{\circ} \circ$ & $37 \cdot 5$ & 15 & 26 & 619 & 0.42 \\
\hline 5 & $37 \cdot 0$ & $66 \cdot 0$ & $29^{\circ} 0$ & I4 & 25 & 619 & 0.32 \\
\hline 22 & $50 \cdot 0$ & 66.0 & 16.0 & I5 & 22 & 619 & 0.18 \\
\hline I4 & $75^{\circ} 0$ & $\mathrm{IO}_{3} \cdot \mathrm{O}$ & 28.0 & I9 & 32 & 493 & 0.39 \\
\hline 13 & $\mathrm{IO} 4.0$ & I I 4.5 & 10.5 & 33 & $4 \mathrm{I}$ & I 24 & 0.59 \\
\hline 64 & I9.5 & 67.0 & $47 \cdot 5$ & 4 & 20 & 619 & 0.53 \\
\hline 65 & $6 \mathrm{I} \cdot 0$ & $99 \cdot 0$ & $38 \cdot 0$ & I9 & 33 & 493 & 0.53 \\
\hline 66 & $38 \cdot 5$ & $82 \cdot 0$ & $43 \cdot 5$ & 6 & 22 & 619 & 0.49 \\
\hline 77 & $28 \cdot 0$ & 43.0 & 15.0 & 9 & I4 & 428 & 0.24 \\
\hline 83 & I9. 5 & $3 \mathrm{I} \cdot 0$ & II 5 & 4 & 9 & 435 & 0.18 \\
\hline 90 & $69 \cdot 0$ & $75^{\circ} 0$ & 6.0 & 20 & I9 & I56 & 0.26 \\
\hline 9I & $59^{\circ} 0$ & $9 \mathrm{I} \cdot 0$ & $32 \cdot 0$ & I 4 & $3 I$ & 588 & 0.38 \\
\hline 3 & $38 \cdot 0$ & $73 \cdot 0$ & $35^{\circ} 0$ & I3 & 24 & 543 & 0.45 \\
\hline 9 & $73 \cdot 0$ & $8 \mathrm{I} \cdot 5$ & 8.5 & 22 & 27 & 183 & 0.32 \\
\hline 20 & $59 \cdot 0$ & $63 \cdot 5$ & $4 \cdot 5$ & $2 \mathrm{I}$ & 22 & 94 & 0.33 \\
\hline 63 & $34 \cdot 5$ & $6 \mathrm{I} \cdot 5$ & $27 \cdot 0$ & 8 & I6 & 566 & 0.33 \\
\hline 2 I & $47^{\circ} \circ$ & $5 \mathrm{I} \cdot 5$ & 4.5 & I 4 & I7 & 222 & 0.14 \\
\hline 80 & $30 \cdot 0$ & $49 \cdot 0$ & $19^{\circ} 0$ & 7 & I7 & 320 & $0.4 \mathrm{I}$ \\
\hline
\end{tabular}

Average elongation rate, $0.31 \mathrm{~cm}$. per week. 


\section{Table XiI. Growth-Rate by Marked Patches of Fucus Vesiculosus AT WEMBURY}

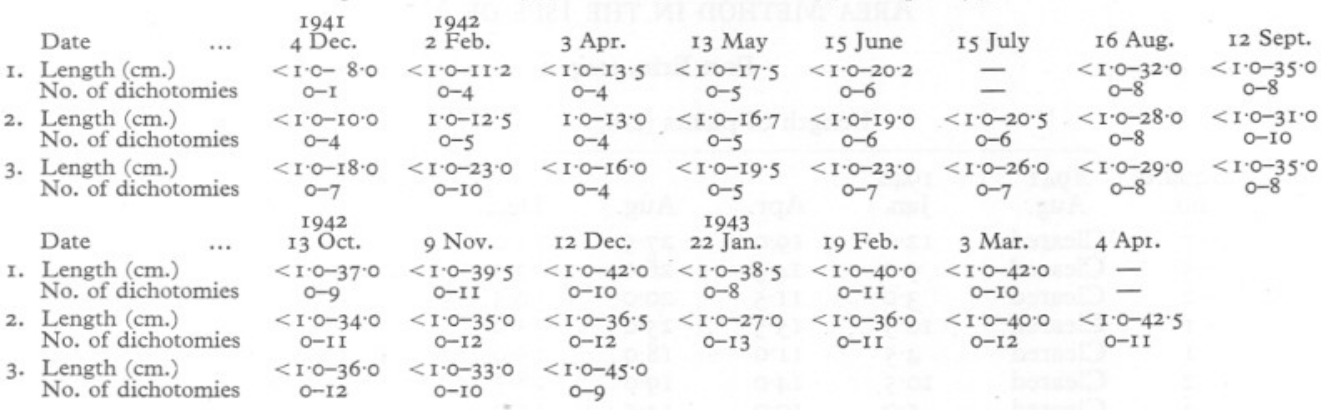

\section{Table XIII. Growth-rate by Marked Patches of FuCUS Vesiculosus AT WEMBURY}

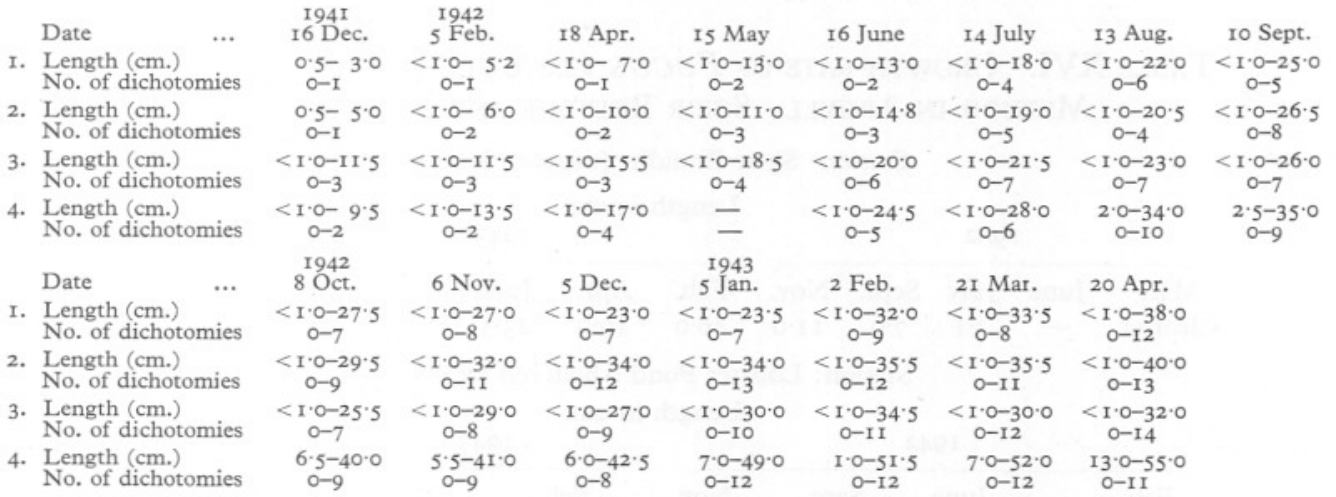

Table XiV. Growth-rate of Fucus vesiculosus by Cleared AREa Method at WeMbury

Metre squares I-I6

\begin{tabular}{|c|c|c|c|}
\hline Square no. & $\begin{array}{l}\text { Period of exp. } \\
\text { (years + days) }\end{array}$ & $\begin{array}{l}\text { Growth-rate } \\
\text { for I year } \\
\text { (cm. per week) }\end{array}$ & $\begin{array}{l}\text { Growth-rate } \\
\text { for whole period } \\
\text { ( } \mathrm{cm} \text {. per week) }\end{array}$ \\
\hline I & 2 y. I93 d. & 0.59 & 0.54 \\
\hline 2 & $2 \mathrm{y} .175 \mathrm{~d}$. & 0.46 & $0.4 \mathrm{I}$ \\
\hline 3 & 2 y. I $44 \mathrm{~d}$. & 0.28 & 0.39 \\
\hline 4 & 2 y. $126 \mathrm{~d}$. & $0.5 \mathrm{I}$ & 0.42 \\
\hline 5 & 2 y. $92 \mathrm{~d}$. & 0.53 & 0.54 \\
\hline 6 & 2 y. 289 d. & $0.4 \mathrm{I}$ & 0.42 \\
\hline 7 & 2 y. 259 d. & 0.46 & 0.40 \\
\hline 8 & 2 y. $200 \mathrm{~d}$. & 0.25 & 0.32 \\
\hline 9 & 2 y. 208 d. & 0.37 & 0.53 \\
\hline Io & 2 y. I79 d. & 0.38 & 0.57 \\
\hline II & 2 y. I50 d. & 0.42 & 0.51 \\
\hline I2 & $2 \mathrm{y}$. II $2 \mathrm{~d}$. & 0.43 & 0.48 \\
\hline I3 & 2 y. 83 d. & 0.49 & 0.56 \\
\hline I4 & 2 y. 49 d. & 0.42 & 0.53 \\
\hline 15 & $2 \mathrm{y} .22 \mathrm{~d}$. & 0.49 & 0.48 \\
\hline 16 & $2 \mathrm{y} .10 \mathrm{~d}$. & $0.4 \mathrm{I}$ & 0.47 \\
\hline
\end{tabular}

Average elongation-rate for I year, $0.43 \mathrm{~cm}$. per week.

Average elongation-rate for whole period, $0.47 \mathrm{~cm}$. per week. 
Table XV. Growth-Rate of Fucus vesiculosus by Cleared AREA Method IN THE IsLe of MaN

\begin{tabular}{|c|c|c|c|c|c|c|c|c|}
\hline \multirow[b]{2}{*}{$\begin{array}{l}\text { Square } \\
\text { no. }\end{array}$} & \multicolumn{6}{|c|}{ Port Erin, strip I } & \multicolumn{2}{|c|}{$\begin{array}{l}\text { Growth-rate } \\
\text { per week }(\mathrm{cm} .)\end{array}$} \\
\hline & $\begin{array}{l}\text { I94I } \\
\text { Aug. }\end{array}$ & $\begin{array}{l}\text { I } 942 \\
\text { Jan. }\end{array}$ & Apr. & Aug. & Dec. & $\begin{array}{l}\text { I943 } \\
\text { Apr. }\end{array}$ & Ist year & $\begin{array}{l}\text { I yr. } \\
9 \text { months }\end{array}$ \\
\hline-7 & Cleared & $12 \cdot 0$ & 19.0 & $27 \cdot 5$ & $3 I \cdot 0$ & $34 \cdot 5$ & $0.5 \mathrm{I}$ & 0.40 \\
\hline-5 & Cleared & 9.0 & $\mathrm{I} 4 \cdot 3$ & 26.0 & $33 \cdot 5$ & $42 \cdot 5$ & $0 \cdot 48$ & 0.49 \\
\hline-2 & Cleared & 3.0 & II. 5 & 20.0 & 30.5 & $4 \mathrm{r} \cdot 5$ & 0.37 & 0.48 \\
\hline$-I$ & Cleared & 10.5 & 15.5 & 25.0 & $35^{\circ} 0$ & $43 \cdot 0$ & $0 \cdot 46$ & 0.49 \\
\hline I & Cleared & $4 \cdot 5$ & II. O & I 8.0 & 25.0 & $37 \cdot 0$ & 0.34 & 0.43 \\
\hline 2 & Cleared & 10.5 & $\mathrm{I} 4.0$ & I9.0 & 28.5 & 39.5 & 0.37 & 0.46 \\
\hline 3 & Cleared & 5.0 & 10.0 & 14.5 & $2 I 0$ & $27 \cdot 0$ & 0.39 & 0.31 \\
\hline 4 & Cleared & 5.0 & II $\cdot O$ & 14.5 & 20.5 & $29 \cdot 0$ & 0.29 & 0.33 \\
\hline 5 & Cleared & $7 \cdot 0$ & $17 \cdot 5$ & $24 \cdot 5$ & $3 I \cdot 5$ & $42 \cdot 5$ & 0.45 & 0.49 \\
\hline I0 & Cleared & 16.0 & $28 \cdot 5$ & $39^{\circ} 0$ & 43.5 & $49 \cdot 5$ & 0.74 & 0.57 \\
\hline
\end{tabular}

Table XVI. Growth-rate of Fucus vesiculosus by Cleared Area Method in Argyll. Sgeir Bhuidhe and Lobster Pond

Station: Sgeir Bhuidhe (exposed locality)

Length in $\mathrm{cm}$.

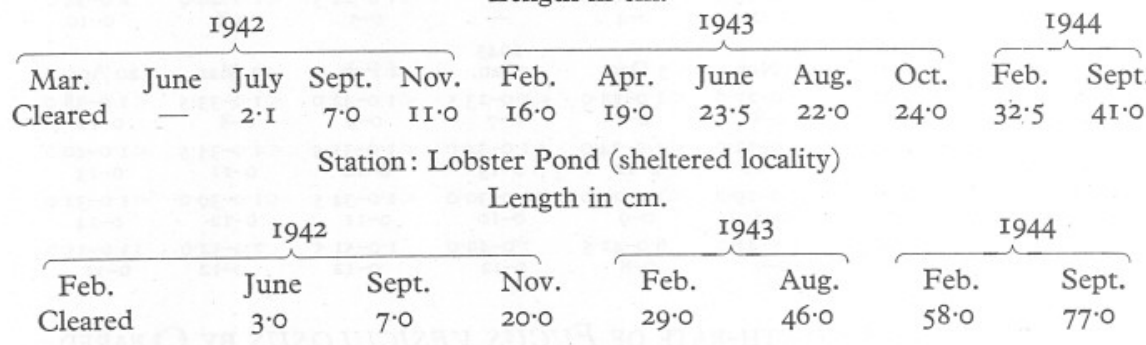

Table XVII. Growth-rate of Fucus vesiculosus by Cleared Area Method in Argyll. Ascophyllum Rock

$\begin{array}{lccc}\text { West strip } & \begin{array}{c}\text { Duration } \\ \text { of exp. } \\ \text { (days) }\end{array} & \begin{array}{c}\text { Increase } \\ \text { in length } \\ \text { (cm.) }\end{array} & \begin{array}{c}\text { Growth-rate } \\ \text { per week } \\ \text { (cm.) }\end{array} \\ \text { Upper level } & 969 & \text { roo } & 0.72 \\ \text { Middle level } & 969 & \text { II9 } & 0.86 \\ \text { Low level } & 969 & 90 & 0.65 \\ \text { Area 3 } & 569 & 68 & 0.83 \\ \text { East Strip } & 8 \mathrm{I9} & \text { I I0 } & 0.93 \\ \text { Square AH I } & 495 & 28 & 0.28 \\ \text { Square AH2 } & 495 & 36 & 0.5 \mathrm{I}\end{array}$

Average growth-rate for the area is $0.68 \mathrm{~cm}$. per week. 
Table XVIII. Growth-Rate by Marked Plants of FUCUS SERRATUS AT WEMBURY

Square 15 on strip

\begin{tabular}{|c|c|c|c|c|c|c|}
\hline Plant no. & $\begin{array}{l}\text { Duration } \\
\text { of exp. } \\
\text { (days) }\end{array}$ & $\begin{array}{l}\text { Increase } \\
\text { in length } \\
\text { (cm.) }\end{array}$ & $\begin{array}{l}\text { Increase } \\
\text { in no. of } \\
\text { dichotomies }\end{array}$ & $\begin{array}{l}\text { Increase } \\
\text { in no. of } \\
\text { tips }\end{array}$ & & $\begin{array}{l}\text { rowth-rate } \\
\text { per week } \\
\text { (cm.) }\end{array}$ \\
\hline $\mathrm{AI}$ & 221 & 17.5 & 6 & 305 & \multirow{7}{*}{\multicolumn{2}{|c|}{$\begin{array}{r}0.51 \\
0.46 \\
0.61 \\
0.36 \\
0.36 \\
\text { Av. } 0.50\end{array}$}} \\
\hline 2 & 273 & I9.0 & 5 & 86 & & \\
\hline 3 & 532 & $36 \cdot 5$ & I2 & 1639 & & \\
\hline 4 & 532 & $39 \cdot 0$ & II & 1929 & & \\
\hline 5 & 243 & $16 \cdot 0$ & 5 & 373 & & \\
\hline 6 & 348 & $30 \cdot 5$ & I0 & & & \\
\hline 7 & 253 & 13.0 & 3 & 156 & & \\
\hline B I & I99 & 23.5 & 7 & 256 & \multirow{9}{*}{ Av. } & 0.83 \\
\hline 2 & 59 & $5 \cdot 8$ & I & $3 \mathrm{I}$ & & 0.68 \\
\hline 3 & 59 & $6 \cdot 5$ & I & 7 & & 0.77 \\
\hline 4 & 570 & $19.5 \max$. & 7 & 499 & & 0.24 \\
\hline 5 & 257 & I8.0 unbroken & 4 & 379 & & 0.49 \\
\hline 6 & II & $12 \cdot 0$ & 2 & 83 & & 0.70 \\
\hline 7 & 550 & $17 \cdot 0$ & 7 & 46 & & $0.2 \mathrm{I}$ \\
\hline 8 & 246 & I 6.0 unbroken & 6 & 52 & & 0.37 \\
\hline 9 & 30 & $3 \cdot 0$ & 0 & 一 & & $\begin{array}{l}0.70 \\
0.55\end{array}$ \\
\hline $\mathrm{C}_{I}$ & 59 & $5 \cdot 0$ & 2 & 75 & \multirow{8}{*}{ Av. } & 0.49 \\
\hline 2 & 59 & 5.0 & 0 & I7 & & 0.49 \\
\hline 3 & 29 & I.5 & I & & & 0.36 \\
\hline 4 & 539 & $45 \cdot 5$ & II & I696 & & 0.59 \\
\hline 5 & II9 & 13.0 & 2 & 77 & & 0.76 \\
\hline 6 & 217 & 15.5 & 3 & $5 \mathrm{I}$ & & 0.50 \\
\hline \multirow{2}{*}{$\begin{array}{l}7 \\
8\end{array}$} & 495 & $3 \mathrm{I} \cdot 0$ & Io & 488 & & 0.44 \\
\hline & 539 & $45 \cdot 5$ & II & I908 & & $\begin{array}{l}0.59 \\
0.53\end{array}$ \\
\hline$D_{\text {I }}$ & I55 & $16 \cdot 5$ & 3 & 47 & \multirow{12}{*}{ Av. } & 0.74 \\
\hline 2 & 59 & $2 \cdot 5$ & I & I5 & & 0.29 \\
\hline 3 & 549 & $7 \cdot 5$ & 4 & 575 & & 0.09 \\
\hline 4 & 257 & I 2.5 unbroken & 4 & 260 & & 0.34 \\
\hline 5 & 296 & $4 \cdot 0$ & 3 & - & & 0.09 \\
\hline 6 & 199 & 6.0 & 2 & - & & 0.18 \\
\hline 7 & 59 & $2 \cdot 5$ & 0 & I7 & & 0.29 \\
\hline 8 & 227 & $2 \mathrm{I} \cdot \mathrm{O}$ & 5 & I73 & & $0.6 \mathrm{I}$ \\
\hline 9 & 199 & $22 \cdot 0$ unbroken & 4 & & & 0.74 \\
\hline ró & 270 & $15 \cdot 0$ & 6 & I8I & & 0.38 \\
\hline \multirow[b]{2}{*}{$\begin{array}{l}11 \\
12\end{array}$} & 199 & I6.0 unbroken & 4 & I37 & & 0.56 \\
\hline & 199 & 20.5 & 4 & 275 & & $\begin{array}{l}0.71 \\
0.42\end{array}$ \\
\hline $\mathrm{E}_{\mathrm{I}}$ & 298 & & 2 & -18 & \multirow{12}{*}{ Av. } & 0.13 \\
\hline 2 & 228 & I 7.5 unbroken & 3 & 34 & & 0.40 \\
\hline 3 & 518 & $38 \cdot 5$ & 10 & I52 & & 0.52 \\
\hline 4 & 313 & 27.5 unbroken & 7 & $26 \mathrm{I}$ & & 0.64 \\
\hline $\begin{array}{l}4 \\
5\end{array}$ & I 49 & 14.5 & 4 & I85 & & 0.68 \\
\hline 6 & $\begin{array}{l}518 \\
518\end{array}$ & $\begin{array}{l}22.5 \\
22 \cdot 5\end{array}$ & 10 & I 40 & & 0.30 \\
\hline 7 & 270 & $19 \cdot 0$ unbroken & 7 & 156 & & 0.49 \\
\hline 8 & $4 \mathrm{I} 7$ & $18 \cdot 0$ & 5 & $5 \mathrm{I}$ & & 0.30 \\
\hline 9 & 270 & 27.5 & 9 & 225 & & $0.7 \mathrm{I}$ \\
\hline ro & 228 & 24.0 & 6 & 546 & & 0.73 \\
\hline II & 518 & 45.0 & I2 & 416 & & 0.57 \\
\hline $\mathrm{I} 2$ & 383 & 16.5 & 6 & $4 \mathrm{I}$ & & $\begin{array}{l}0.35 \\
0.40\end{array}$ \\
\hline $\mathrm{F}_{\mathrm{I}}$ & & 56.5 & & & \multirow{8}{*}{ Av. } & $\begin{array}{l}0.49 \\
0.80\end{array}$ \\
\hline 2 & $\begin{array}{l}143 \\
\mathrm{I} 93\end{array}$ & $\begin{array}{l}10.3 \\
17.5\end{array}$ & 4 & $\begin{array}{l}164 \\
164\end{array}$ & & 0.63 \\
\hline 3 & $\begin{array}{r}59 \\
59\end{array}$ & 7.0 & $\begin{array}{l}4 \\
1\end{array}$ & $\begin{array}{r}\text { I0 } \\
\text { I0 }\end{array}$ & & 0.83 \\
\hline 4 & 544 & $60 \cdot 0$ & $\mathrm{I} 4$ & 419 & & 0.77 \\
\hline 5 & 291 & $6 \cdot 5$ & I & 15 & & 0.15 \\
\hline 6 & 544 & $38 \cdot 5$ & I2 & I386 & & 0.49 \\
\hline \multirow{3}{*}{$\begin{array}{l}7 \\
8\end{array}$} & 544 & 35.5 & Io & 409 & & 0.45 \\
\hline & 544 & 34.5 & 13 & 220 & \multirow{2}{*}{\multicolumn{2}{|c|}{ Av. $\begin{array}{l}0.44 \\
0.57\end{array}$}} \\
\hline & & & & & & \\
\hline
\end{tabular}

Average elongation rate, $0.50 \mathrm{~cm}$. per week. 
Table XIX. Growth-rate by Marked Plants of Fucus serratus AT WEMBURY

Square $2 \mathrm{I}$ on strip

\begin{tabular}{|c|c|c|c|c|c|c|c|}
\hline \multirow{2}{*}{$\begin{array}{c}\text { Plant } \\
\text { no. }\end{array}$} & \multicolumn{3}{|c|}{ Length (cm.) } & \multicolumn{2}{|c|}{ No. of dichotomies } & \multirow{2}{*}{$\begin{array}{c}\text { Duration } \\
\text { of exp. } \\
\text { (days) }\end{array}$} & \multirow{2}{*}{$\begin{array}{l}\text { Growth- } \\
\text { rate per } \\
\text { week }(\mathrm{cm} .)\end{array}$} \\
\hline & Initial & Final & Increase & Initial & Final & & \\
\hline I & $\mathrm{I} 4 \cdot \mathrm{O}$ & $\begin{array}{l}5 \mathrm{I} \cdot 0 \mathrm{~F} . \\
52.0 \mathrm{M} .\end{array}$ & $\begin{array}{l}37 \cdot 0 \\
38 \cdot 0\end{array}$ & 6 & $\underline{23}$ & $\begin{array}{l}989 \\
727\end{array}$ & $\begin{array}{l}0.26 \\
0.36\end{array}$ \\
\hline 2 & $28 \cdot 0$ & $80 \cdot 0$ & $52 \cdot 0$ & 9 & 25 & 989 & 0.36 \\
\hline 3 & 13.5 & $6 \mathrm{I} \cdot 0$ & $47 \cdot 5$ & 6 & 23 & 989 & $0: 33$ \\
\hline 4 & $8 \cdot 0$ & $70 \cdot 0$ & $62 \cdot 0$ & 3 & 25 & 989 & 0.43 \\
\hline 5 & I 4.0 & $62 \cdot 5$ & $45 \cdot 5$ & 5 & $2 \mathrm{I}$ & 989 & 0.32 \\
\hline 6 & I3.5 & $5 I \cdot 5$ & 38.0 & 6 & 20 & 606 & 0.44 \\
\hline 7 & 25.0 & $36 \cdot 5$ & II. 5 & 9 & $\mathrm{I} 2$ & 338 & 0.23 \\
\hline 8 & $9 \cdot 5$ & I 2.0 & $2 \cdot 5$ & 4 & 6 & $28 \mathrm{I}$ & 0.06 \\
\hline 9 & -13.0 & $42 \cdot 0$ & 29.0 & 4 & I2 & 309 & 0.65 \\
\hline IO & $12 \cdot 0$ & $32 \cdot 5$ & $20 \cdot 5$ & 3 & IO & 309 & 0.42 \\
\hline I I & 36.0 & $64^{\circ} 0$ & $28 \cdot 0$ & II & I6 & 309 & 0.63 \\
\hline 12 & I 4.0 & 28.5 & I 4.5 & 6 & I2 & 212 & 0.47 \\
\hline I3 & 20.0 & $40 \cdot 0$ & $20 \cdot 0$ & 6 & I5 & $33^{8}$ & $0.4 \mathrm{I}$ \\
\hline I4 & II.O & $3 I \cdot O$ & 20.0 & 4 & 9 & 3 I I & 0.45 \\
\hline I5 & 8.0 & 27.0 & I9.0 & 3 & 8 & 254 & 0.52 \\
\hline I6 & 10.0 & I $4 \cdot 2$ & $4 \cdot 2$ & 5 & 8 & 163 & 0.18 \\
\hline I7 & 10.5 & 30.8 & $20 \cdot 3$ & 3 & 8 & 254 & 0.56 \\
\hline I8 & I I. 5 & 34.0 & $22 \cdot 5$ & 2 & 8 & $28 \mathrm{I}$ & 0.56 \\
\hline I9 & $7 \cdot 5$ & $4 \mathrm{I} \cdot 0$ & $33 \cdot 5$ & 2 & I3 & $4 \mathrm{I} 5$ & 0.56 \\
\hline 20 & 9.0 & 27.5 & I 8.5 & 5 & I I & 254 & 0.50 \\
\hline $2 I$ & 14.5 & 39.5 & $25 \cdot 0$ & 4 & IO & 338 & $0.5 \mathrm{I}$ \\
\hline 22 & I 4.0 & $40 \cdot 0$ & 26.0 & 4 & I I & 338 & 0.53 \\
\hline 23 & $7 \cdot 5$ & $37^{\circ} 0$ & $29 \cdot 5$ & 3 & I2 & 338 & $0.6 \mathrm{I}$ \\
\hline 24 & $6 \cdot 0$ & 34.0 & 28.0 & 2 & IO & 373 & 0.52 \\
\hline
\end{tabular}

Average elongation-rate, $0.43 \mathrm{~cm}$. per week.

Table XXI. Growth-rate by Marked Plants of Fucus SerRatus AT WEMBURY

\begin{tabular}{|c|c|c|c|c|c|c|c|}
\hline \multirow{3}{*}{$\begin{array}{l}\text { Plant } \\
\text { no. }\end{array}$} & \multicolumn{5}{|c|}{ Square I6 on strip } & \multirow{3}{*}{$\begin{array}{l}\text { Duration } \\
\text { of exp. } \\
\text { (days) }\end{array}$} & \multirow{3}{*}{$\begin{array}{c}\text { Growth- } \\
\text { rate per } \\
\text { week }(\mathrm{cm} .)\end{array}$} \\
\hline & \multicolumn{3}{|c|}{ Length (cm.) } & No. of d & hotomies & & \\
\hline & Initial & Final & Increase & Initial & Final & & \\
\hline I65 & $12 \cdot 5$ & $39 \cdot 0$ & $26 \cdot 5$ & 5 & I6 & 824 & 0.22 \\
\hline 303 & $8 \cdot 0$ & $45^{\circ} \circ$ & $37 \cdot 0$ & 3 & 17 & 764 & 0.33 \\
\hline 288 & 13.5 & $66 \cdot 0$ & $52 \cdot 5$ & 6 & 26 & 943 & 0.39 \\
\hline $30 I$ & $9 \cdot 5$ & $48 \cdot 0$ & $38 \cdot 5$ & 3 & I5 & 635 & 0.42 \\
\hline 167 & IO.O & 59.5 & $49 \cdot 5$ & 3 & $2 \mathrm{I}$ & 855 & 0.40 \\
\hline I60 & I 4.0 & 39.5 & 25.5 & 5 & I4 & 372 & $0.4^{8}$ \\
\hline I68 & 14.5 & I9. 5 & $5 \cdot 0$ & 5 & 8 & 303 & O.I I \\
\hline I7 I & $\mathrm{I} 4.0$ & $38 \cdot 5$ & 24.5 & 5 & I4 & 372 & 0.46 \\
\hline I73 & I I.O & $3^{8 \cdot 0}$ & 27.0 & 4 & I I & 372 & 0.48 \\
\hline I75 & $17 \cdot 0$ & $38 \cdot 5$ & $2 I \cdot 5$ & 8 & I3 & $27 I$ & 0.55 \\
\hline 294 & 9.0 & $27 \cdot 5$ & I $8 \cdot 5$ & 3 & 9 & 253 & $0.5 \mathrm{I}$ \\
\hline 297 & 12.0 & $28 \cdot 5$ & 16.5 & 5 & IO & 253 & 0.45 \\
\hline 298 & 10.5 & 33.5 & 23.0 & 5 & I 2 & 372 & 0.44 \\
\hline 304 & 10.5 & $44^{\circ} 0$ & 33.5 & 6 & I5 & 635 & 0.36 \\
\hline 305 & 6.0 & 17.0 & I I.O & 2 & IO & 532 & O.I4 \\
\hline 307 & $7 \cdot 5$ & 29.5 & 22.0 & 2 & I I & 342 & 0.45 \\
\hline 308 & 6.0 & 30.0 & $24^{\circ} 0$ & I & IO & 342 & 0.49 \\
\hline $43^{8}$ & $7 \cdot 5$ & 26.0 & 18.5 & 2 & 9 & 253 & $0.5 \mathrm{I}$ \\
\hline I70 & $17 \cdot 0$ & $3 I \cdot 0$ & $\mathrm{I} 4^{\circ} \mathrm{O}$ & 6 & I I & 222 & 0.44 \\
\hline
\end{tabular}

Average elongation-rate, $0.40 \mathrm{~cm}$. per week. 
Table XX. Growth-Rate by Marked Plants of Fucus serratus AT WEMBURY

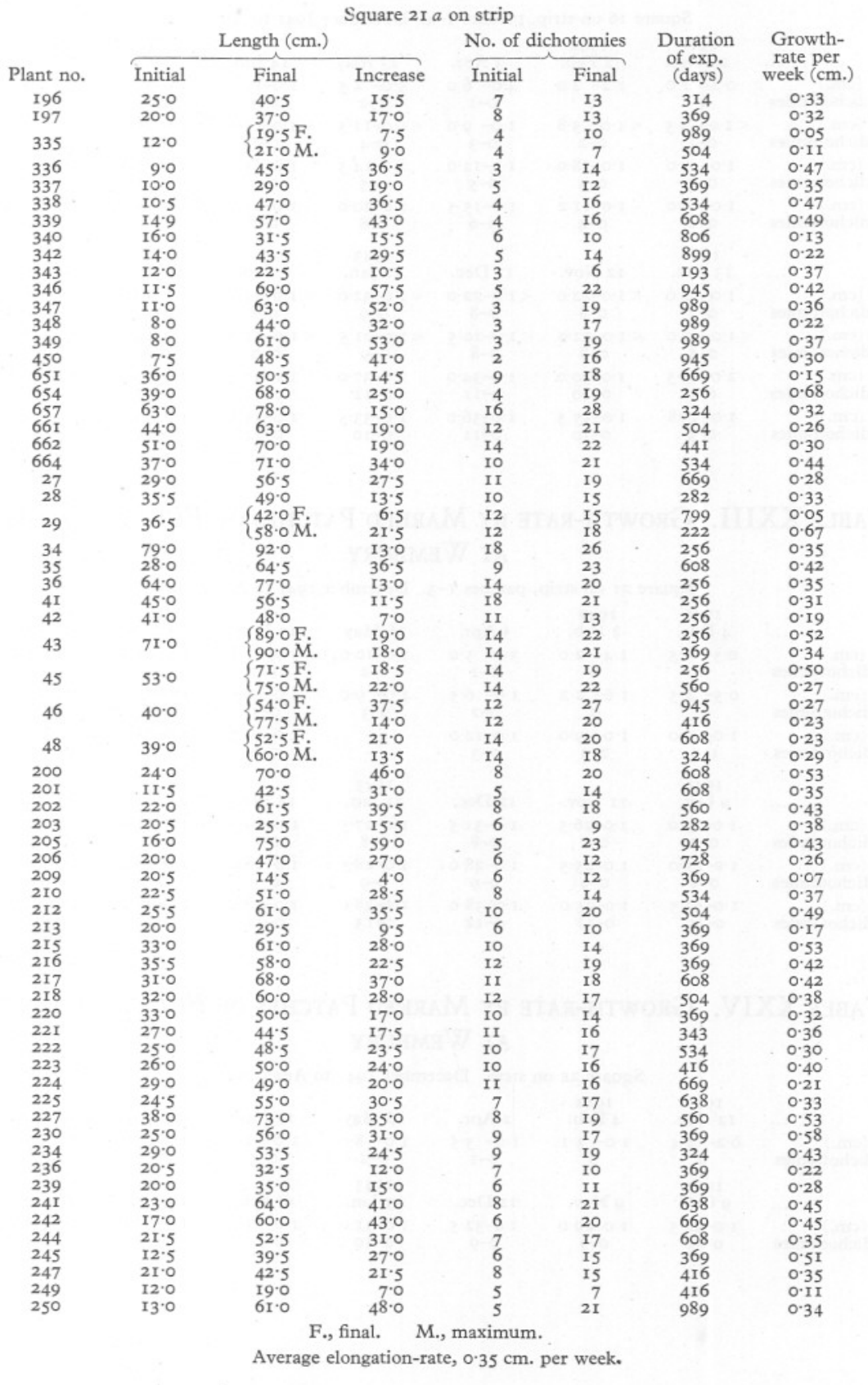

JOURN. MAR. BIOL. ASSOC. vol. XXIX, I950 


\section{Table XXII. Growth-Rate by Marked Patches of Fucus SerRatus AT WEMBURY}

Square I6 on strip, patches I-4. December I94I to April 1943

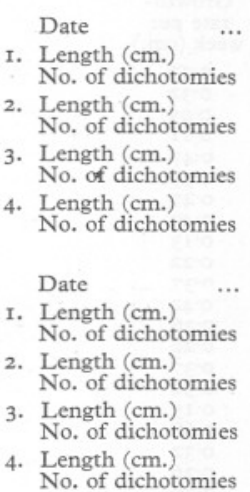

\begin{tabular}{|c|c|c|c|c|c|c|}
\hline $\begin{array}{c}\text { I94I } \\
22 \text { Dec. } \\
0.2-\text { I.O } \\
0\end{array}$ & $\begin{array}{c}1942 \\
2 \mathrm{Feb} \\
\mathrm{I} \cdot 2-2 \cdot 0 \\
0\end{array}$ & $\begin{array}{l}3 \text { Apr. } \\
4.0-6.0 \\
0-1\end{array}$ & $\begin{array}{l}\text { I3 May } \\
5 \cdot 0-8 \cdot 5 \\
\mathrm{I}-2\end{array}$ & $\begin{array}{l}\text { I4 June } \\
\text { r.0-ro.5 } \\
0-3\end{array}$ & $\begin{array}{l}\text { I5 July } \\
\text { I.0-I } 2 \cdot 5 \\
0-4\end{array}$ & $\begin{array}{l}\text { I5 Aug. } \\
\text { I. } 0-20 \cdot 0 \\
0-5\end{array}$ \\
\hline $\begin{array}{l}\mathrm{I} \cdot \mathrm{O}-3.5 \\
0-\mathrm{I}\end{array}$ & $\begin{array}{c}<1 \cdot 0-3 \cdot 8 \\
0-2\end{array}$ & $\begin{array}{c}1 \cdot 0-9.0 \\
0-3\end{array}$ & $\begin{array}{c}<\mathrm{I} \cdot \mathrm{O}-\mathrm{II} \cdot \mathrm{I} \\
\mathrm{O}-4\end{array}$ & $\begin{array}{c}<1 \cdot 0-15 \cdot 5 \\
0-6\end{array}$ & $\begin{array}{c}<\mathrm{I} \cdot 0-16 \cdot 0 \\
0-6\end{array}$ & $\begin{array}{c}<1 \cdot 0-20 \cdot 0 \\
0-6\end{array}$ \\
\hline $\begin{array}{c}1 \cdot 0-5 \cdot 0 \\
0-1\end{array}$ & $\begin{array}{c}I \cdot O-8.0 \\
O-3\end{array}$ & $\begin{array}{c}1 \cdot 0-12 \cdot 0 \\
0-5\end{array}$ & $\begin{array}{c}\mathrm{I} \cdot \mathrm{O}-\mathrm{I} 4 \cdot \mathrm{S} \\
0-5\end{array}$ & $\begin{array}{c}1 \cdot 0-15.5 \\
0-5\end{array}$ & $\begin{array}{c}I \cdot 5-19 \cdot 5 \\
0-7\end{array}$ & $\begin{array}{c}1 \cdot 0-24 \cdot 5 \\
0-7\end{array}$ \\
\hline $\begin{array}{c}r \cdot 0-9.0 \\
0-2\end{array}$ & $\begin{array}{c}I \cdot O-I I \cdot 2 \\
0-4\end{array}$ & $\begin{array}{c}1 \cdot 0-15 \cdot 5 \\
0-6\end{array}$ & $\begin{array}{c}I \cdot 0-20 \cdot 0 \\
0-8\end{array}$ & $\begin{array}{c}I \cdot 0-23 \cdot 0 \\
0-7\end{array}$ & $\begin{array}{c}I \cdot 0-20 \cdot 5 \\
0-7\end{array}$ & $\begin{array}{c}I \cdot 0-27 \cdot 0 \\
0-8\end{array}$ \\
\hline $\begin{array}{l}1942 \\
\text { I3 Oct. } \\
\text { I. } 0-2 \text { I. } \\
0-7\end{array}$ & $\begin{array}{l}\text { I2 Nov. } \\
<\text { I. } 0-22 \cdot 0 \\
0-8\end{array}$ & $\begin{array}{l}\text { I2 Dec. } \\
<\mathrm{I} \cdot 0-22 \cdot 0 \\
0-8\end{array}$ & $\begin{array}{c}\text { I943 } \\
22 \text { Jan. } \\
<\text { I.0-32.0 } \\
0-9\end{array}$ & $\begin{array}{c}7 \text { Feb. } \\
<\mathrm{I} \cdot 0-23.5 \\
0-8\end{array}$ & $\begin{array}{l}2 \text { I Mar. } \\
<\text { I.O-34.O } \\
\text { O-I I }\end{array}$ & $\begin{array}{l}22 \text { Apr. } \\
<\text { I }^{\circ} 0-25^{\circ} 0 \\
0-9\end{array}$ \\
\hline $\begin{array}{c}I \cdot 0-22 \cdot 0 \\
0-8\end{array}$ & $\begin{array}{c}<\mathrm{I} \cdot 0-22 \cdot 0 \\
0-8\end{array}$ & $\begin{array}{c}<\mathrm{I} \cdot 0-20 \cdot 5 \\
0-8\end{array}$ & $\begin{array}{c}<\mathrm{I} \cdot 0-2 \mathrm{I} \cdot 5 \\
0-9\end{array}$ & $\begin{array}{c}<\mathrm{I} \cdot 0-2 \mathrm{I} \cdot 5 \\
0-9\end{array}$ & $\begin{array}{c}<\mathrm{I} \cdot 0-24 \cdot 5 \\
0-8\end{array}$ & $\begin{array}{c}<\mathrm{I} \cdot 0-28 \cdot 5 \\
0-7\end{array}$ \\
\hline $\begin{array}{c}2.0-29 \cdot 5 \\
0-9\end{array}$ & $\begin{array}{c}1 \cdot 0-30 \cdot 0 \\
0-10\end{array}$ & $\begin{array}{c}I \cdot 0-34 \cdot 0 \\
0-I I\end{array}$ & $\begin{array}{c}\mathrm{I} \cdot \mathrm{O}-37 \cdot \mathrm{O} \\
\mathrm{O}-\mathrm{I} 2\end{array}$ & $\begin{array}{c}\mathrm{I} \cdot \mathrm{O}-38 \cdot 5 \\
\mathrm{O}-\mathrm{II}\end{array}$ & $\begin{array}{c}I \cdot 0-39 \cdot 5 \\
0-I I\end{array}$ & $\begin{array}{c}\mathrm{I} \cdot \mathrm{O}-43 \cdot \mathrm{O} \\
\mathrm{O}-\mathrm{I} 3\end{array}$ \\
\hline $\begin{array}{c}\text { I. } 0-33.8 \\
0-9\end{array}$ & $\begin{array}{c}I \cdot 0-355 \\
0-10\end{array}$ & $\begin{array}{c}\mathrm{I} \cdot 0-36 \cdot 0 \\
0-\mathrm{II}\end{array}$ & $\begin{array}{c}1 \cdot 0-33.5 \\
0-10\end{array}$ & $\begin{array}{c}1 \cdot 0-35 \cdot 5 \\
0-12\end{array}$ & $\begin{array}{c}\mathrm{I} \cdot 0-35 \cdot 5 \\
0-\mathrm{II}\end{array}$ & $\begin{array}{c}\mathrm{I} \cdot \mathrm{O}-37 \cdot 0 \\
\mathrm{O}-\mathrm{I} 2\end{array}$ \\
\hline
\end{tabular}

\section{Table XXIII. Growth-Rate by Marked Patches of FuCUS SERRAtus AT WEMBURY}

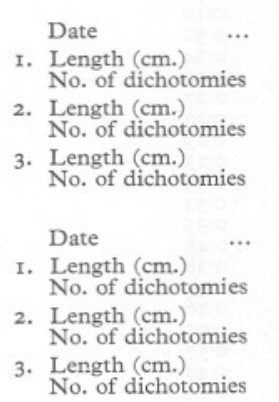
Square 2 I on strip, patches I-3. December I94I to April I943

\begin{tabular}{|c|c|c|c|c|c|c|c|}
\hline $\begin{array}{c}\text { I94I } \\
4 \text { Dec. } \\
0.5-I \cdot 5 \\
0\end{array}$ & $\begin{array}{c}\text { I } 942 \\
2 \mathrm{Feb} \\
\mathrm{I} \cdot 4-2 \cdot 0 \\
0\end{array}$ & $\begin{array}{l}5 \text { Apr. } \\
3.0-5 \cdot 0 \\
0-1\end{array}$ & $\begin{array}{c}\text { I6 May } \\
\text { I.0-I0.0 } \\
\text { I-2 }\end{array}$ & $\begin{array}{l}\text { I5 June } \\
\mathrm{I} \cdot 0-\mathrm{I} \cdot 2 \\
\mathrm{I}-3\end{array}$ & $\begin{array}{c}\text { Is July } \\
\text { I.0-15.5 } \\
0-4\end{array}$ & $\begin{array}{l}\text { I5 Aug. } \\
\text { I. } 0-20.0 \\
0-5\end{array}$ & $\begin{array}{c}\text { I2 Sept. } \\
\text { I'0-2I'5 } \\
0-5\end{array}$ \\
\hline $0.5-1.5$ & $I \cdot 6-2 \cdot 2$ & $\begin{array}{c}1.0-6.5 \\
0-2\end{array}$ & $\begin{array}{c}1 \cdot 0-9.0 \\
0-3\end{array}$ & $\begin{array}{c}1 \cdot 0-10 \cdot 5 \\
0-3\end{array}$ & $\begin{array}{c}I \cdot O-13.5 \\
0-4\end{array}$ & $\begin{array}{c}I \cdot 0-20 \cdot 0 \\
0-6\end{array}$ & $\begin{array}{c}I \cdot 0-25 \cdot C \\
0-9\end{array}$ \\
\hline $\begin{array}{c}I \cdot 0-9.0 \\
I-2\end{array}$ & $\begin{array}{c}I \cdot 0-9 \cdot 0 \\
2-3\end{array}$ & $\begin{array}{c}I \cdot O-12 \cdot 0 \\
0-3\end{array}$ & Z & $\begin{array}{c}1 \cdot 0-19.5 \\
0-6\end{array}$ & $\begin{array}{c}I \cdot 0-23 \cdot 0 \\
0-8\end{array}$ & $\begin{array}{c}I \cdot 0-3 I \cdot 0 \\
0-8\end{array}$ & $\begin{array}{c}I \cdot 0-3 I \cdot 0 \\
0-8\end{array}$ \\
\hline $\begin{array}{c}1942 \\
9 \text { Oct. } \\
\text { I.0-25.0 } \\
0-7\end{array}$ & $\begin{array}{c}\text { I I Nov. } \\
\text { I. } 0-26 \cdot 5 \\
0-7\end{array}$ & $\begin{array}{l}\text { I2 Dec. } \\
\text { I.0-3I'5 } \\
0-8\end{array}$ & $\begin{array}{c}1943 \\
2 \text { I Jan. } \\
\text { I.0-27.5 } \\
0-8\end{array}$ & $\begin{array}{c}\text { I8 Feb. } \\
\text { I.0-29.5 } \\
0-9\end{array}$ & $\begin{array}{l}\text { 2I Mar. } \\
\text { I.0-3I.0 } \\
0-10\end{array}$ & $\begin{array}{c}22 \text { Apr. } \\
\text { I. } 0-22 \cdot 0 \\
0-7\end{array}$ & \\
\hline $\begin{array}{c}\mathrm{I} \cdot \mathrm{O}-25 \cdot \mathrm{O} \\
0-9\end{array}$ & $\begin{array}{c}I \cdot 0-25 \cdot 5 \\
0-9\end{array}$ & $\begin{array}{c}I \cdot O-28 \cdot 0 \\
0-9\end{array}$ & $\begin{array}{c}I \cdot 0-28 \cdot 5 \\
0-9\end{array}$ & $\begin{array}{c}1 \cdot 0-26 \cdot 0 \\
0-9\end{array}$ & $\begin{array}{c}I \cdot 0-25 \cdot 5 \\
0-9\end{array}$ & $\begin{array}{c}\mathrm{I} \cdot 0-23.0 \\
0-9\end{array}$ & \\
\hline $\begin{array}{c}1 \cdot 0-33.5 \\
0-10\end{array}$ & $\begin{array}{c}I \cdot 0-35 \cdot 0 \\
0-I I\end{array}$ & $\begin{array}{c}I \cdot 0-38 \cdot 0 \\
0-12\end{array}$ & $\begin{array}{c}\mathrm{I} \cdot \mathrm{O}-38 \cdot \mathrm{O} \\
\mathrm{O}-\mathrm{I} 3\end{array}$ & $\begin{array}{c}I \cdot O-38 \cdot 0 \\
O-I I\end{array}$ & $\begin{array}{c}1 \cdot 0-38 \cdot 0 \\
0-13\end{array}$ & $\begin{array}{c}\mathrm{I}^{\prime} \mathrm{O}-44^{\circ} \mathrm{O} \\
\mathrm{O}-\mathrm{r} 3\end{array}$ & \\
\hline
\end{tabular}

\section{Table XXIV. Growth-Rate by Marked Patches of FuCUS SERRATUS AT WEMBURY}

Square 22 on strip. December I 94 I to April 1943

\begin{tabular}{|c|c|c|c|c|c|c|c|c|}
\hline $\begin{array}{l}\text { Date } \\
\text { Length (cm.) } \\
\text { No. of dichotomies }\end{array}$ & $\begin{array}{c}\text { I94I } \\
\text { I2 Dec. } \\
0.2-2 \cdot 4 \\
0\end{array}$ & $\begin{array}{c}\mathrm{I} 942 \\
4 \mathrm{Feb} . \\
\mathrm{I} \cdot \mathrm{O}-\mathrm{O}^{3 \cdot \mathrm{I}} \\
0\end{array}$ & $\begin{array}{c}2 \text { Apr. } \\
\text { I.0- } 5.5 \\
0-1\end{array}$ & $\begin{array}{l}\text { I6 May } \\
\mathrm{I} \cdot 0-8 \cdot 0 \\
0-2\end{array}$ & $\begin{array}{c}\text { Is June } \\
\text { I.0-I I. } \\
0-4\end{array}$ & $\begin{array}{c}\text { Is July } \\
\text { I.0-I5.5 } \\
0-5\end{array}$ & $\begin{array}{l}\text { Is Aug. } \\
\text { I.0-19.0 } \\
0-5\end{array}$ & $\begin{array}{c}\text { I2 Sept. } \\
I \cdot 0-2 I \cdot 5 \\
0-6\end{array}$ \\
\hline $\begin{array}{l}\text { Date } \\
\text { Length (cm.) } \\
\text { No. of dichotomies }\end{array}$ & $\begin{array}{c}1942 \\
9 \text { Oct. } \\
\text { I.0-24.5 } \\
0-10\end{array}$ & $\begin{array}{l}9 \text { Nov. } \\
1 \cdot 0-29 \cdot 0 \\
0-9\end{array}$ & $\begin{array}{l}\text { I2 Dec. } \\
\begin{array}{c}\text { I. } 0-32 \cdot 5 \\
0-9\end{array}\end{array}$ & $\begin{array}{c}\text { I943 } \\
23 \mathrm{Jan} . \\
\mathrm{I} \cdot 0-3 \mathrm{I} \cdot 0 \\
0-10\end{array}$ & $\begin{array}{l}18 \mathrm{Feb} . \\
1 \cdot 0-33 \cdot 0 \\
0-10\end{array}$ & $\begin{array}{l}\text { I3 Mar. } \\
\text { I.0-32.0 } \\
0-12\end{array}$ & $\begin{array}{l}22 \mathrm{Apr} . \\
\mathrm{I} \cdot 0-36 \cdot 0 \\
0-12\end{array}$ & \\
\hline
\end{tabular}




\section{Table XXV. Growth-Rate of Fucus serratus by Cleared}

Area Method at Wembury

\begin{tabular}{|c|c|c|c|c|c|c|}
\hline & & & re sque & $\mathrm{HI}-3, \mathrm{~L}_{\mathrm{I}-\mathrm{I}}$ & & \\
\hline $\begin{array}{c}\text { Square } \\
\text { no. }\end{array}$ & $\begin{array}{l}\text { Period } \\
\text { (days) }\end{array}$ & $\begin{array}{l}\text { Growth- } \\
\text { rate per } \\
\text { week (cm.) }\end{array}$ & $\begin{array}{c}\text { Period } \\
\text { (days) }\end{array}$ & $\begin{array}{l}\text { Growth- } \\
\text { rate per } \\
\text { week }(\mathrm{cm} .)\end{array}$ & $\begin{array}{l}\text { Total period } \\
\text { (years + days) }\end{array}$ & $\begin{array}{l}\text { Growth- } \\
\text { rate per } \\
\text { week (cm.) }\end{array}$ \\
\hline $\mathrm{HI}$ & 372 & 0.57 & 728 & $0.5 \mathrm{I}$ & 2 y. 33 I d. & 0.56 \\
\hline 2 & 365 & 0.49 & 733 & 0.82 & 2 y. 287 d. & $0.5 \mathrm{I}$ \\
\hline 3 & 367 & 0.46 & 725 & 0.55 & 2 y. $97 \mathrm{~d}$. & 0.60 \\
\hline $\mathrm{LI}_{\mathrm{I}}$ & 368 & 0.57 & 755 & 0.44 & 2 y. 346 d. & 0.50 \\
\hline 2 & 368 & 0.70 & 727 & 0.64 & 2 y. $309 \mathrm{~d}$. & 0.62 \\
\hline 3 & 379 & 0.60 & 735 & 0.60 & 2 y. $226 \mathrm{~d}$. & 0.56 \\
\hline 4 & $38 \mathrm{I}$ & 0.34 & 733 & 0.40 & 2 y. I79 d. & 0.45 \\
\hline 5 & 373 & 0.60 & 728 & 0.62 & 2 y. I 42 d. & 0.57 \\
\hline 6 & 371 & 0.34 & 729 & 0.42 & 2 y. I00 d. & $0.4 \mathrm{I}$ \\
\hline 7 & 383 & 0.39 & 724 & 0.55 & 2 y. $\quad 78$ d. & 0.46 \\
\hline 8 & 353 & 0.44 & 738 & 0.57 & 2 y. $\quad 35 \mathrm{~d}$. & 0.63 \\
\hline 9 & 356 & 0.47 & 749 & 0.57 & - & - \\
\hline Io & 387 & 0.52 & $7 \mathrm{II}$ & 0.43 & - & - \\
\hline II & $35^{8}$ & 0.60 & 683 & 0.65 & - & - \\
\hline I 2 & 360 & 0.23 & 656 & 0.32 & - & - \\
\hline I3 & 356 & 0.74 & 616 & 0.67 & - & - \\
\hline I4 & 357 & 0.54 & 583 & 0.55 & 一 & - \\
\hline I5 & 353 & 0.43 & 553 & 0.62 & - & - \\
\hline I6 & 370 & 0.46 & 516 & 0.58 & - & - \\
\hline
\end{tabular}

Average elongation-rate: Plants approximately I year old, $0.50 \mathrm{~cm}$. per week.

Plants I-2 years old, $0.55 \mathrm{~cm}$. per week.

Plants 2-3 years old, $0.53 \mathrm{~cm}$. per week.

\section{Table XXVI. Growth-rate of FUCUS SERRATUS and FUCUS Vesiculosus by Cleared Area Method at Wembury}

Square I9 on strip

F. vesiculosus

$\overbrace{\text { Length }}^{\begin{array}{c}\text { No. of } \\ \text { dichotomies }\end{array}}$

5. iv. 42 Rock surface removed

28. iv. 42 No repopulation

I3. v. 42

I7. vi. 42

I5. vii. 42

I4. viii. 42

I3. ix. 42

I4. X. 42

26. x. 42

12. xi. 42

8. xii. 42

2I. i. 43

I8. ii. 43

2I. iii. 43

22. iv. 43

22. v. 43

I6. vi. 43

3I. vii. 43

I. ix. 43

3. x. 43

I. xi. 43

9. xii. 43

Io. i. 44

9. ii. 44

I4. iii. 44

9. iv. 44

II. v. 44

7. vi. 44

6. vii. 44

22. viii. 44

$$
\begin{aligned}
& O \cdot 5-I \cdot 0 \\
& O \cdot I-4 \cdot 0 \\
& O \cdot I-4 \cdot 0 \\
& O \cdot I-4 \cdot 0 \\
& O \cdot I-7 \cdot 0 \\
& O \cdot I-I 2 \cdot 0 \\
& O \cdot I-I 4 \cdot 5 \\
& O \cdot I-I 6 \cdot 3 \\
& O \cdot I-20 \cdot 5 \\
& O \cdot I-I 7 \cdot 5 \\
& O \cdot I-I 5 \cdot 5 \\
& O \cdot I-I 9 \cdot 0 \\
& O \cdot I-20 \cdot 0 \\
& O \cdot I-24 \cdot 3 \\
& O \cdot I-26 \cdot 5 \\
& O \cdot I-32 \cdot 0 \\
& O \cdot I-36 \cdot 0 \\
& O \cdot I-42 \cdot 5 \\
& O \cdot I-45 \cdot 0 \\
& O \cdot I-49 \cdot 0 \\
& O \cdot I-47 \cdot 0 \\
& O \cdot I-43 \cdot 0 \\
& O \cdot I-46 \cdot 5 \\
& O \cdot I-49 \cdot 0 \\
& O \cdot I-50 \cdot 0 \\
& O \cdot I-46 \cdot 5 \\
& O \cdot I-58 \cdot 0 \\
& O \cdot I-62 \cdot 0
\end{aligned}
$$

\begin{tabular}{|c|c|}
\hline $0.5-1.0$ & 0 \\
\hline $0 . \mathrm{I}-4.0$ & I \\
\hline $0 . I-4.0$ & I \\
\hline $0 . I-4.0$ & I \\
\hline $0 . \mathrm{I}-7.0$ & I \\
\hline $0.1-9 \cdot 2$ & 4 \\
\hline - & - \\
\hline $0 . \mathrm{I}-\mathrm{I} 2.0$ & 4 \\
\hline $0 . I-I 6.6$ & 6 \\
\hline $0 . \mathrm{I}-\mathrm{I} 5.0$ & 6 \\
\hline $0.1-20.0$ & 6 \\
\hline $0 . I-24.5$ & 7 \\
\hline $0.1-23.0$ & 5 \\
\hline $0.1-30.5$ & 9 \\
\hline $0 . I-35.5$ & 9 \\
\hline $0.1-36.0$ & II \\
\hline $0 . I-40 \cdot 0$ & II \\
\hline $0 . I-47.5$ & I3 \\
\hline $0 . I-49 \cdot 0$ & IO \\
\hline $0 . \mathrm{I}-47 \cdot 0$ & $\mathrm{I} 2$ \\
\hline $0 . I-52 \cdot 0$ & I 2 \\
\hline $0 . I-53.0$ & I3 \\
\hline $0.1-55^{\circ} \mathrm{O}$ & I4 \\
\hline $0.1-60.0$ & I6 \\
\hline $0 \cdot I-64 \cdot 0$ & I6 \\
\hline $0.1-62.5$ & I4 \\
\hline $0 . \mathrm{I}-72.0$ & 1 \\
\hline
\end{tabular}

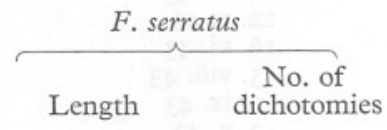

Average elongation-rate over a period of 2 years 129 days: $F$. vesiculøsus, $0.50 \mathrm{~cm}$. per week. $F$. serratus, $0.58 \mathrm{~cm}$. per week. 
Table XXVII. Growth-Rate of FuCUS SERratus by Cleared ARea Method at Wembury

Square I9A 2 on strip

\begin{tabular}{|c|c|c|c|}
\hline \multicolumn{2}{|c|}{ Length (cm.) } & \multicolumn{2}{|c|}{ No. of dichotomies } \\
\hline $\begin{array}{l}\text { Plants } \\
\text { on rock }\end{array}$ & $\begin{array}{l}\text { Plants on } \\
\text { edge of pool }\end{array}$ & $\begin{array}{l}\text { Plants } \\
\text { on rock }\end{array}$ & $\begin{array}{l}\text { Plants on } \\
\text { edge of pool }\end{array}$ \\
\hline
\end{tabular}

9. ix. $4 \mathrm{I} \quad$ Rock surface scraped
6. $\mathrm{x}$. $4 \mathrm{I}$
$<\mathrm{I}-2 \cdot \mathrm{O}$

$\begin{array}{ll}\text { 6. } x .4 I & <\mathrm{I}-2 \cdot 0 \\ \text { 8. } \mathrm{x} .4 \mathrm{I} & \text { Rock surface removed }\end{array}$

I7. xi. $4 \mathrm{I}$ No repopulation

4. xii. $4 \mathrm{I}$ No repopulation

30. iii. 42

I3. v: 42

I5. vi. 42

I5. vii. 42

I4. viii. 42

I3. ix. 42

I4. X. 42

9. xi. 42

12. xii. 42

2I. i. 43

I8. ii. 43

2I. iii. 43

24. iv. 43

22. v. 43

I6. vi. 43

5. viii. 43

I. ix. 43

3. x. 43

I. $x i .43$

9. xii. 43

IO. i. 44

I2. ii. 44

9. iv. 44

II. v. 44

7. vi. 44

6. vii. 44

$<\mathrm{I}-2.0$
$\mathrm{I}-5.0$

$\mathrm{I}-5.0$
$\mathrm{I}-8.0$

I-I $2 \cdot 5$

$\mathrm{I}-\mathrm{I} 4 \cdot \mathrm{O}$

I-I 6.0

I-I $7 \cdot 7$

I -23.5

I -29.0

$\mathrm{I}-24 . \mathrm{O}$

$\mathrm{I}-34 . \mathrm{O}$

$\mathrm{I}-3 \mathrm{I} \cdot \mathrm{O}$

$\mathrm{I}-30.0$

$\mathrm{I}-36.0$

$\mathrm{I}-38.0$

$\mathrm{I}-45^{\circ} \mathrm{O}$

I -46.0

$\mathrm{I}-48.0$

I -52.0

I $-49^{\circ} \mathrm{O}$

I -50.0

$\mathrm{I}-55^{\circ} \mathrm{O}$

$\mathrm{I}-60 \cdot 0$

I $-54^{\circ} 0$

I -56.0

I $-72 \cdot 0$

22. viii. 44

$\mathrm{I}-76.0$

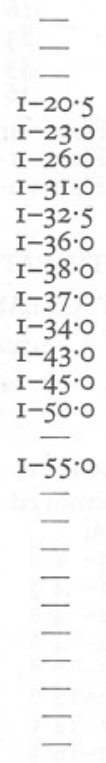

$\begin{array}{rr}\text { O } & - \\ 1 & - \\ 2 & - \\ 3 & 5 \\ 7 & 7 \\ 6 & 7 \\ 7 & 8 \\ 6 & 8 \\ 10 & 8 \\ 7 & 9 \\ 8 & 9 \\ 9 & 9 \\ 9 & 10 \\ 10 & 10 \\ 10 & 9 \\ 10 & - \\ \text { I2 } & \text { I2 } \\ 8 & - \\ \text { 15 } & - \\ \text { 14 } & - \\ \text { I6 } & - \\ \text { I6 } & - \\ \text { 16 } & - \\ 17 & - \\ \text { I6 } & - \\ 19 & - \\ 20 & -\end{array}$

Average elongation-rate over period of 2 years 348 days: $0.49 \mathrm{~cm}$. per week.

Average elongation-rate of plants near pool over period of 722 days: $0.53 \mathrm{~cm}$. per week. 
Table XXVIII. Growth-rate of Fucus serratus by Cleared AREA METHOD IN THE ISLE OF MAN

Port Erin Bay, strips I-3

Strip I. August I94I to September I944

Length of plants $(\mathrm{cm}$.)

\begin{tabular}{|c|c|c|c|c|c|c|c|c|c|}
\hline $\begin{array}{c}\text { Square } \\
\text { no. }\end{array}$ & $\begin{array}{c}\text { I94I } \\
5 \text { Aug. }\end{array}$ & $\begin{array}{l}\text { 1942 } \\
2 \text { Jan. }\end{array}$ & I9 Apr. & 7 July & Io Dec. & $\begin{array}{l}\text { I943 } \\
\text { I6 Apr. } 2\end{array}$ & 20 Sept. & $\begin{array}{l}\text { I944 } \\
\text { I Jan. }\end{array}$ & I5 Apr. \\
\hline IO & Cleared & $8 \cdot 0$ & $16 \cdot 0$ & $28 \cdot 5$ & $30 \cdot 5$ & $38 \cdot 0$ & - & - & - \\
\hline II & Cleared & $8 \cdot 5$ & 15.0 & $26 \cdot 0$ & 38.5 & 44.5 & 53.5 & 一 & $76 \cdot 0$ \\
\hline I2 & Cleared & 3.0 & II. 5 & I9.0 & $32 \cdot 0$ & $4 \mathrm{I} \cdot 0$ & $45^{\circ} 0$ & - & $68 \cdot 0$ \\
\hline I3 & Cleared & $7 \cdot 5$ & $12 \cdot 5$ & I 4.0 & 39.5 & $50 \cdot 0$ & $4 \mathrm{I} \cdot 0$ & $38 \cdot 0$ & $64 \cdot 0$ \\
\hline I4 & Cleared & II.O & 14.5 & $20 \cdot 5$ & $27 \cdot 5$ & $3 I \cdot 0$ & $45^{\circ} 0$ & $45^{\circ} 0$ & $69 \cdot 0$ \\
\hline 15 & Cleared & $9 \cdot 0$ & 16.0 & $25^{\circ} 0$ & 28.0 & $29 \cdot 0$ & $32 \cdot 0$ & 50.0 & $73 \cdot 0$ \\
\hline I6 & Cleared & $7 \cdot 5$ & I 8.5 & 25.0 & $30 \cdot 0$ & 36.5 & 60.5 & 65.0 & 60.5 \\
\hline I7 & Cleared & II $\cdot 0$ & $20 \cdot 5$ & $29 \cdot 5$ & $3 I \cdot 5$ & $37 \cdot 0$ & $5 \mathrm{I} \cdot 0$ & $57 \cdot 0$ & $73 \cdot 0$ \\
\hline 18 & Cleared & I3.5 & I9.0 & $36 \cdot 0$ & $42 \cdot 0$ & $36 \cdot 5$ & $50 \cdot 0$ & $6 \mathrm{I} \cdot 0$ & $78 \cdot 0$ \\
\hline I9 & Cleared & I 4.5 & 19.5 & $30 \cdot 0$ & $39 \cdot 0$ & 43.0 & $59 \cdot 0$ & $66 \cdot 5$ & $77 \cdot 5$ \\
\hline 20 & Cleared & II. 5 & 20.0 & 30.5 & $34 \cdot 0$ & $38 \cdot 0$ & $58 \cdot 0$ & 63.0 & $75 \cdot 5$ \\
\hline $2 \mathrm{I}$ & Cleared & $6 \cdot 5$ & $16 \cdot 0$ & $3 I \cdot 0$ & $38 \cdot 5$ & $43 \cdot 0$ & $62 \cdot 5$ & $50 \cdot 0$ & $78 \cdot 5$ \\
\hline 22 & Cleared & I 4.0 & $22 \cdot 0$ & $3 I \cdot 5$ & $40 \cdot 0$ & $50 \cdot 0$ & $48 \cdot 5$ & $57 \cdot 0$ & $71 \cdot 0$ \\
\hline 23 & Cleared & IO. 0 & $2 \mathrm{I} \cdot 0$ & $3 I \cdot 0$ & 37.5 & $48 \cdot 0$ & $42 \cdot 0$ & $54 \cdot 5$ & $6 \mathrm{I} \cdot 5$ \\
\hline 24 & Cleared & $8 \cdot 5$ & $16 \cdot 0$ & $27 \cdot 0$ & $32 \cdot 5$ & 37.0 & $43 \cdot 0$ & $55^{\circ} 0$ & $76 \cdot 0$ \\
\hline 25 & Cleared & 3.0 & 6.0 & 16.0 & $25^{\circ} 0$ & $34 \cdot 5$ & - & - & $64 \cdot 0$ \\
\hline 26 & Cleared & $7 \cdot 5$ & I5.5 & $37 \cdot 5$ & $45 \cdot 0$ & 43.0 & - & - & $72 \cdot 0$ \\
\hline 27 & Cleared & 一 & $I \cdot 0$ & $17 \cdot 0$ & 29.0 & $36 \cdot 5$ & - & - & $56 \cdot 0$ \\
\hline
\end{tabular}

Average elongation-rate, $0.57 \mathrm{~cm}$. per week.

Strip 2. April I942 to September I944 (843 days)

Av. length of Rate of growth

$\begin{array}{ccc}\text { Square no. } & \begin{array}{c}\text { Io longest plants } \\ (\mathrm{cm} .)\end{array} & \begin{array}{c}\text { per week } \\ \text { (cm.) }\end{array} \\ \text { II } & 65.5 & 0.53 \\ \text { I2 } & 70.0 & 0.56 \\ \text { I3 } & 73.0 & 0.59 \\ \text { I4 } & 78.0 & 0.63\end{array}$

Average elongation-rate, $0.58 \mathrm{~cm}$. per week.

Strip 3. August 1942 to September 1944 ( 762 days)

Av. length of Rate of growth

$\begin{array}{ccc}\text { Square no. } & \begin{array}{c}\text { Io longest plants } \\ (\mathrm{cm} .)\end{array} & \begin{array}{c}\text { per week } \\ (\mathrm{cm} .)\end{array} \\ \text { I3 } & 75.5 & 0.69 \\ \text { I4 } & 76.4 & 0.70 \\ \text { I5 } & 71.8 & 0.65 \\ \text { I6 } & 73.1 & 0.67\end{array}$

Average elongation-rate, $0.68 \mathrm{~cm}$. per week. 


\section{Table XXIX. Growth-rate of Fucus serratus by Cleared Area Method in the Isle of Man}

Port St Mary and Castletown

\section{Port St Mary}

Length of plants (cm.)

\begin{tabular}{|c|c|c|c|c|c|}
\hline \multirow{3}{*}{$\begin{array}{c}\text { Square no. } \\
\text { I }\end{array}$} & & \multirow{2}{*}{$\begin{array}{c}\text { Growth-rate } \\
\text { per week } \\
\text { (cm.) }\end{array}$} \\
\hline & $\begin{array}{l}\text { I943 } \\
\text { I2 Apr. }\end{array}$ & 7 Aug. & 3I Dec. & $\begin{array}{c}\text { I944 } \\
\text { I7 Apr. }\end{array}$ & \\
\hline & 0 & $\mathrm{I} 4.0$ & 25.0 & 34.0 & 0.64 \\
\hline 2 & 0 & 15.5 & 27.0 & $37 \cdot 2$ & 0.70 \\
\hline 3 & 0 & 17.5 & $3 \mathrm{I} \cdot 5$ & $45 \cdot 0$ & 0.85 \\
\hline 4 & 0 & II.O & $22 \cdot 5$ & $3 \mathrm{I} \cdot 0$ & 0.58 \\
\hline 5 & 0 & 10.5 & 23.5 & $47 \cdot 8$ & 0.90 \\
\hline
\end{tabular}

Average elongation-rate, $0.73 \mathrm{~cm}$. per week.

Scarlet Point, Castletown

Length of plants (cm.)

\begin{tabular}{|c|c|c|c|c|c|}
\hline \multirow{3}{*}{$\begin{array}{c}\text { Square no. } \\
\text { I }\end{array}$} & \multicolumn{4}{|c|}{ Length or piants (cm.) } & \multirow{2}{*}{$\begin{array}{c}\text { Growth-rate } \\
\text { per week } \\
\text { (cm.) }\end{array}$} \\
\hline & $\begin{array}{l}\text { I943 } \\
\text { I3 Apr. }\end{array}$ & 9 Aug. & 3I Dec. & $\begin{array}{l}\text { I } 944 \\
\text { r8 Apr. }\end{array}$ & \\
\hline & 0 & I5.O & $26 \cdot 5$ & $39 \cdot 5$ & 0.74 \\
\hline 2 & 0 & $17 \cdot 5$ & 30.5 & $42 \cdot 5$ & 0.80 \\
\hline 3 & 0 & I9.0 & $32 \cdot 5$ & $49^{\circ} 0$ & 0.90 \\
\hline 4 & 0 & 15.5 & $27 \cdot 0$ & $39 \cdot 0$ & 0.74 \\
\hline 5 & 0 & $17 \cdot 5$ & $33 \cdot 5$ & 55.5 & I.O4 \\
\hline
\end{tabular}

Average elongation-rate, $0.84 \mathrm{~cm}$. per week.

Table XXX. Growth-Rate of Marked Plants of Fucus serratus IN ARgyll. Serratus Rock

\begin{tabular}{|c|c|c|c|c|}
\hline Plant no. & $\begin{array}{l}\text { Duration } \\
\text { of exp. } \\
\text { (days) }\end{array}$ & $\begin{array}{l}\text { Increase } \\
\text { in length } \\
(\mathrm{cm} .)\end{array}$ & $\begin{array}{l}\text { Increase } \\
\text { in no. of } \\
\text { dichotomies }\end{array}$ & $\begin{array}{l}\text { Growth-rate } \\
\text { per week } \\
\text { (cm.) }\end{array}$ \\
\hline A I & 1041 & $74 \cdot 0$ & IO & 0.50 \\
\hline 2 & 245 & $22 \cdot 5$ & 4 & 0.64 \\
\hline 3 & 496 & 68.0 & I0 & 0.93 \\
\hline 4 & 308 & $43 \cdot 0$ & 4 & 0.97 \\
\hline 5 & 308 & 30.5 & 5 & 0.69 \\
\hline 6 & 248 & $26 \cdot 5$ & 6 & 0.75 \\
\hline 7 & 248 & I9.0 & 3 & 0.53 \\
\hline 8 & 192 & $35 \cdot 0$ & 4 & $I \cdot 27$ \\
\hline $\mathrm{B}$ I & 520 & $74 \cdot 0$ & 8 & 0.99 \\
\hline 2 & 248 & $32 \cdot 5$ & 2 & 0.91 \\
\hline 3 & 248 & 38.0 & 7 & $\mathrm{I} \cdot 07$ \\
\hline 4 & 248 & 39.0 & 5 & $I \cdot I O$ \\
\hline 5 & I90 & 30.5 & 3 & $I \cdot I 2$ \\
\hline 6 & 248 & 44.5 & 5 & $I \cdot 82$ \\
\hline 7 & 248 & $47^{\circ} \circ$ & 6 & $I \cdot 32$ \\
\hline $\mathrm{CI}_{\mathrm{I}}$ & 248 & $35^{\circ} 0$ & 5 & 0.98 \\
\hline 2 & 248 & $32 \cdot 0$ & 5 & 0.90 \\
\hline 3 & 248 & 38.0 & 6 & I.07 \\
\hline 4 & 443 & $24 \cdot 5$ & 2 & 0.38 \\
\hline 5 & 443 & $47^{\circ} \circ$ & 6 & 0.74 \\
\hline 6 & 248 & $32 \cdot 5$ & 5 & $0.9 \mathrm{I}$ \\
\hline 7 & 520 & II $\cdot 5$ & 2 & 0.15 \\
\hline 8 & 248 & $3 I \cdot 0$ & 5 & 0.87 \\
\hline
\end{tabular}

Average elongation-rate, $0.90 \mathrm{~cm}$. per week. 
Table XXXI. Growth-rate of Fucus serratus by Cleared AREA Method IN ARgYlL

\begin{tabular}{|c|c|c|c|c|c|c|}
\hline \multicolumn{3}{|c|}{ Serratus Rock } & \multicolumn{4}{|c|}{ Ascophyllum Rock } \\
\hline Square no. & $\begin{array}{c}\text { Duration } \\
\text { of exp. } \\
\text { (days) }\end{array}$ & $\begin{array}{l}\text { Growth-rate } \\
\text { per week } \\
(\mathrm{cm} .)\end{array}$ & Square no. & $\begin{array}{l}\text { Duration } \\
\text { of exp. } \\
\text { (days) }\end{array}$ & $\begin{array}{l}\text { Length } \\
\text { of plant } \\
\text { (cm.) }\end{array}$ & $\begin{array}{l}\text { Growth-rate } \\
\text { per week } \\
\text { (cm.) }\end{array}$ \\
\hline EI & 315 & 0.88 & West strip: 3 , & IO3I & & \\
\hline $\mathrm{E}_{2}$ & 315 & $1 \cdot 06$ & 5 and 6 & IO3I & $90 \cdot 0$ & 0.66 \\
\hline $\mathrm{E}_{3}$ & 315 & $\mathrm{I} \cdot 08$ & Average $\mathrm{e}$ & longation-1 & ate for are & \\
\hline $\begin{array}{l}\mathrm{A} \mathrm{I}_{1} \\
\mathrm{~A}_{2}\end{array}$ & $\begin{array}{l}385 \\
385\end{array}$ & 0.83 & 0.5 & $7 \mathrm{~cm}$. per & reek. & \\
\hline $\mathrm{B}$ and $\mathrm{C}$ & $\begin{array}{l}385 \\
385\end{array}$ & $\begin{array}{l}0.72 \\
I \cdot 10\end{array}$ & & & & \\
\hline $\mathrm{D}$ & 385 & 0.90 & & & & \\
\hline I & 982 & 0.78 & & & & \\
\hline 2 & 238 & $0.9 \mathrm{I}$ & & . & & \\
\hline 3 & I 78 & 0.82 & & & & \\
\hline
\end{tabular}

Average elongation-rate for area, $0.91 \mathrm{~cm}$. per week.

\section{Table XXXII. Weights of Fucoid Populations in Devon and Argyll}

Devon. Wembury strip $3 \mathrm{~m}$. wide

\begin{tabular}{|c|c|c|c|c|c|}
\hline \multirow[b]{2}{*}{ Experimental area } & \multirow{2}{*}{$\begin{array}{l}\text { No. of months } \\
\text { of growth }\end{array}$} & \multicolumn{3}{|c|}{ Species present on areas } & \multirow{2}{*}{$\begin{array}{l}\text { Wt. in } \\
\text { kg. per m }\end{array}$} \\
\hline & & F.v. & F.s. & $A$. & \\
\hline \multicolumn{6}{|c|}{ Devon. Wembury strip, $3 \mathrm{~m}$. wide } \\
\hline Square 4: & Original population & - & + & + & $15 \cdot 6$ \\
\hline East & 36 & + & + & - & I $4 \cdot 8$ \\
\hline Middle & 36 & + & + & + & $\mathrm{I} 4 \cdot 3$ \\
\hline West & 36 & + & + & + & 15.7 \\
\hline Square 8 & 36 & - & + & - & 15.6 \\
\hline Square I4: & 16 & + & + & - & $7 \cdot 9$ \\
\hline High level & 28 & + & + & - & \\
\hline Low level & $\stackrel{28}{2}$ & + & + & - & $9 \cdot 2$ \\
\hline Square I5: & Original population & - & + & + & $9 \cdot I$ \\
\hline $\begin{array}{l}\text { (a) } \\
\text { (b) }\end{array}$ & $\begin{array}{l}34 \\
34\end{array}$ & - & + & - & II 5 \\
\hline $\begin{array}{ll}(b) \\
\text { Square I6 }\end{array}$ & $\begin{array}{l}34 \\
36\end{array}$ & $\overline{-}$ & $\begin{array}{l}+ \\
+\end{array}$ & $\overline{-}$ & $\begin{array}{l}12 \cdot 3 \\
22 \cdot 0\end{array}$ \\
\hline Square 19 & Original population & - & + & - & $\begin{array}{r}22 \cdot 9 \\
9 \cdot 7\end{array}$ \\
\hline & 28 & + & + & - & I7. \\
\hline Square I9 $a:$ Sout & $3 I$ & - & + & - & $20 \cdot 0$ \\
\hline Nort & $3 I$ & - & + & - & $7 \cdot 5$ \\
\hline Square $2 \mathrm{I}$ & Original population & - & + & - & I $2 \cdot 4$ \\
\hline & 36 & - & + & - & $22 \cdot 2$ \\
\hline Square 2r $a$ & 36 & - & + & - & $9 \cdot 2$ \\
\hline \multicolumn{6}{|c|}{ Ascophyllum Rock: } \\
\hline West strip I & 33 & - & + & + & 13.0 \\
\hline 2 & 33 & + & + & + & $4 \cdot 6$ \\
\hline 3 & 33 & - & + & + & $9 \cdot 9$ \\
\hline East strip & 33 & - & + & - & $42 \cdot 4$ \\
\hline Area 3 & $\begin{array}{l}33 \\
16\end{array}$ & $\bar{t}$ & $\begin{array}{l}+ \\
+\end{array}$ & $\bar{t}$ & $\begin{aligned} 2 \cdot I \\
2 \cdot 2\end{aligned}$ \\
\hline \multicolumn{6}{|l|}{ Serratus Rock: } \\
\hline I & Original population & - & + & - & I3.I \\
\hline & 33 & - & + & - & I 3.3 \\
\hline 2 & Original population & - & + & - & 27.9 \\
\hline Lobster Pond & Original por & - & + & - & $\begin{array}{r}25.5 \\
6.8\end{array}$ \\
\hline & $\begin{array}{l}\text { Original population } \\
\qquad 27\end{array}$ & $\begin{array}{l}+ \\
+\end{array}$ & $\begin{array}{l}- \\
-\end{array}$ & + & $\begin{array}{l}0.0 \\
6.7\end{array}$ \\
\hline Sgeir Bhuidhe & 27 & + & - & - & 6.7 \\
\hline
\end{tabular}

F.v. $=F$. vesiculosus; F.s. $=F$. serratus; A. =Ascophyllum. 
Table XXXiV. Analysis of Population in Size Groups. PORT ERIN

Strip. I. Fucus vesiculosus and Fucus serratus. Original population

\begin{tabular}{|c|c|c|c|c|c|}
\hline Metre & Total & Under & & & Over \\
\hline sq. no. & no. plants & IO $\mathrm{cm}$. & $10-29 \mathrm{~cm}$. & $29-59 \mathrm{~cm}$ & $59 \mathrm{~cm}$ \\
\hline I & I 24 & $5 I$ & 43 & 20 & IO \\
\hline 2 & 847 & 802 & 28 & I4 & 3 \\
\hline 3 & 962 & 902 & 30 & 27 & 3 \\
\hline 4 & 332 & 235 & 50 & 42 & 5 \\
\hline 5 & 788 & 729 & 37 & 20 & 2 \\
\hline 6 & 660 & 319 & 301 & $3^{8}$ & 2 \\
\hline 7 & 310 & 305 & 5 & - & - \\
\hline 8 & I 66 & II 54 & I0 & 2 & - \\
\hline 9 & 2168 & $215 \mathrm{I}$ & I2 & 5 & - \\
\hline IO & $42 I$ & 394 & I7 & 8 & 2 \\
\hline I I & 393 & 326 & 46 & I5 & 6 \\
\hline I2 & 243 & 202 & 20 & I8 & 3 \\
\hline I3 & 597 & 560 & $2 I$ & I4 & 2 \\
\hline I4 & 907 & 835 & $4 \mathrm{I}$ & 25 & 6 \\
\hline I5 & 957 & 843 & 43 & 59 & I2 \\
\hline I6 & 876 & 7 I3 & 39 & 86 & 38 \\
\hline I7 & 904 & 762 & 77 & 45 & 20 \\
\hline I8 & I258 & $80 I$ & 380 & 37 & 40 \\
\hline I9 & 755 & 665 & 25 & 30 & 35 \\
\hline 20 & I I 50 & 1008 & 45 & 63 & 34 \\
\hline $2 I$ & 433 & 344 & 46 & 29 & I4 \\
\hline 22 & 636 & 589 & $3 I$ & I6 & - \\
\hline 23 & 720 & 645 & $6 I$ & I4 & - \\
\hline 24 & $38 \mathrm{I}$ & $3 \mathrm{I} 4$ & 43 & 24 & - \\
\hline 25 & I4 & 3 & 3 & 8 & - \\
\hline 26 & 27 & 26 & I & - & - \\
\hline 27 & 47 & I4 & I5 & I8 & - \\
\hline
\end{tabular}

Strip 2. Original population

$\begin{array}{rrrrrr}\text { II } & 68 & 27 & 28 & \text { I2 } & \text { I } \\ \text { I2 } & \text { I2 } & 0 & 7 & 3 & 2 \\ \text { I3 } & 3132 & 3095 & \text { I9 } & \text { I6 } & 2 \\ \text { I4 } & 98 \text { I } & 943 & 38 & - & - \\ \text { I5 } & 2977 & 2945 & \text { I0 } & \text { I9 } & 3 \\ \text { I6 } & \text { I637 } & 1597 & 7 & 26 & 7 \\ \text { I7 } & 4615 & 4535 & \text { I4 } & 53 & \text { I3 }\end{array}$

Strip 2. Final population. F. vesiculosus

$\begin{array}{lrrrrr}\text { II } & \text { 2I4 } & \text { I83 } & 20 & 4 & 7 \\ \text { I2 } & \text { I88 } & 4 I & 4 I & 69 & 37 \\ \text { I3 } & 6 I 4 & 5 I 8 & 38 & 44 & \text { I4 } \\ \text { I4 } & 98 I & 943 & \text { I8 } & \text { I3 } & 7 \\ \text { I5 } & - & - & - & - & - \\ \text { I6 } & 98 & 64 & 32 & - & - \\ \text { I7 } & 2 \text { I8 } & \text { I77 } & \text { 2I } & 20 & -\end{array}$

Strip 2. Final population. F. serratus

$\begin{array}{rrrrrr}\text { II } & \text { I25 } & 58 & 37 & 24 & 6 \\ \text { I2 } & 305 & \text { I60 } & 57 & 77 & 9 \\ \text { I3 } & 481 & 281 & 78 & 103 & \text { I9 } \\ \text { I4 } & 700 & 391 & 177 & \text { I06 } & 26 \\ \text { I5 } & 626 & 470 & \text { I09 } & 47 & -17 \\ \text { I6 } & \text { II94 } & 750 & 273 & 133 & 38 \\ \text { I7 } & \text { III4 } & 670 & 249 & 175 & 20\end{array}$

Strip 3. Final population. F. serratus

$\begin{array}{lrllll}\text { I3 } & \text { I248 } & 390 & 423 & 393 & 42 \\ \text { I4 } & 866 & \text { I92 } & 320 & 296 & 58 \\ \text { I5 } & \text { III0 } & \text { II4 } & 536 & 414 & 46 \\ \text { I6 } & \text { I2I2 } & 536 & 453 & \text { I76 } & 47\end{array}$


Table XXXiII. Sequence of Reproductive Stages through the Year in Fucus vesiculosus on the Devon Coast as shown by a Number of Individual Plants Size of plants
Area I, Dec. 19442 Occurrence of different stages in receptacle development and maturation. Stages I-9 (see p. 474). S indicates whole plant sterile

\section{Area II, Dec. $194^{2}$}

\begin{tabular}{|c|c|c|c|c|c|c|c|c|c|c|c|c|c|c|c|c|c|c|c|c|c|c|c|c|c|c|}
\hline $\begin{array}{l}\text { Length } \\
\text { (cm.) }\end{array}$ & $\begin{array}{c}\text { No. of } \\
\text { dichotomies }\end{array}$ & $\begin{array}{l}\text { I942 } \\
\text { Mar. }\end{array}$ & Apr. & June & July & Aug. & Sept. & Oct. & Nov. & $\begin{array}{l}\text { I943 } \\
\text { Jan. }\end{array}$ & Feb. & Mar. & Apr. & May & June & July & Oct. & Nov. & Dec. & $\begin{array}{l}\text { I944 } \\
\text { Jan. }\end{array}$ & Mar. & Apr. & May & June & July & Aug. \\
\hline $9 \cdot 0$ & 2 & S & S & S & S & S & $\underset{S}{S}$ & $S$ & S & - & I & 3,4 & 6 & 6 & 6 & $7-9$ & 9, S & $9, \mathrm{~S}$ & $9, \mathrm{~S}$ & Gone & - & - & - & - & - & - \\
\hline $16 \cdot 0$ & 5 & S & S & $\mathrm{S}$ & $\mathrm{S}$ & $\mathrm{S}$ & S & S & $\mathrm{S}_{\mathrm{c}}$ & 2 & 2 & - & - & - & $9, \mathrm{~S}$ & $9, S$ & $9, \mathrm{~S}$ & $9, \mathrm{~S}$ & $9, \mathrm{~S}$ & $9, \mathrm{~S}$ & $9, \mathrm{~S}$ & Gone & - & - & - & - \\
\hline $22 \cdot 0$ & 6 & 4 & 6 & 6,7 & 7,8 & 7,8 & 8 & 9, S. & 9, S S & $3,4,9$ & $2,4,9$ & $4,6,9$ & $4,6,9$ & $6-9$ & $6-9$ & $9, \mathrm{~S}$ & Gone & - & - & - & - & - & - & - & - & - \\
\hline $\begin{array}{l}24.0 \\
26.0\end{array}$ & $\begin{array}{r}10 \\
6\end{array}$ & 4,9 & $\underset{6}{5,9}$ & $6, \underset{6}{6}, 9$ & $\begin{array}{c}7,8,9 \\
7,8\end{array}$ & $\begin{array}{l}8,9 \\
7,8\end{array}$ & $\begin{array}{c}8,9 \\
8\end{array}$ & $\begin{array}{l}\text { 9, S } \\
\text { o,s }\end{array}$ & $\begin{array}{l}9, \mathrm{~S} \\
9, \mathrm{~S}\end{array}$ & Gone & $1, \overline{4}, 9$ & $4, \overline{6}, 9$ & $=$ & $\overline{6-9}$ & $\overline{6-9}$ & $\overline{7-0}$ & $\overline{8,0}$ & $\overline{\text { Gone }}$ & 二 & 二 & E & $=$ & 二 & 二 & 二 & $\bar{z}$ \\
\hline $34^{\circ} \circ$ & 9 & 5 & 6,7 & 7 & 8 & $\begin{array}{l}7,8 \\
8\end{array}$ & 8 & $9, \mathrm{~S}$ & 9, S & $-4,9$ & $\begin{array}{l}1,3,6,9\end{array}$ & $4,6,9$ & 6,9 & $7-9$ & $7-9$ & $\begin{array}{l}7-9 \\
7-9\end{array}$ & $\begin{array}{l}0,9 \\
9, S\end{array}$ & $\mathrm{I}, 9$ & $\overline{9, S}$ & $9, \mathrm{~S}$ & $9, \mathrm{~S}$ & $9, \mathrm{~S}$ & $\overline{9, S}$ & $9, \mathrm{~S}$ & $\overline{9, \mathrm{~S}}$ & Gone \\
\hline 36.0 & $\begin{array}{r}9 \\
56\end{array}$ & $\begin{array}{l}5,9 \\
5,9\end{array}$ & $\begin{array}{l}5,9 \\
6,9\end{array}$ & $\begin{array}{r}6,7,9 \\
6,7,8,9\end{array}$ & $\begin{array}{l}6-9 \\
7-9\end{array}$ & $\begin{array}{l}8,9 \\
7-9\end{array}$ & $\begin{array}{l}8,9 \\
8,9\end{array}$ & $\begin{array}{r}9, \mathrm{~S} \\
9, \mathrm{~S}\end{array}$ & $\begin{array}{l}9, \mathrm{~S} \\
9, \mathrm{~S}\end{array}$ & $\begin{array}{r}\text { I, } 4,9 \\
3,4,9\end{array}$ & $\begin{array}{l}\mathrm{I}, 4,9 \\
\text { Gone }\end{array}$ & $4,6,9$ & $4,6,9$ & 6,9 & $6-9$ & 7-9 & 8,9 & $9, \mathrm{~S}$ & I, 9 & $1,3,9$ & 6,9 & Gone & & 二 & - & $=$ \\
\hline $\begin{array}{l}440^{\circ} \\
44.0\end{array}$ & $\begin{array}{l}16 \\
18\end{array}$ & $\begin{array}{l}5,9 \\
5,9\end{array}$ & $\begin{array}{l}6,9 \\
6,9\end{array}$ & $\begin{array}{c}6,7,8,9 \\
7,9\end{array}$ & $\begin{array}{l}7-9 \\
7-9\end{array}$ & ㄱ-9 & $\begin{array}{l}8,9 \\
8,9\end{array}$ & $9, \mathrm{~s}$ & 9, S & $\begin{array}{l}3,4,9 \\
2,3,9\end{array}$ & $\begin{array}{l}\text { Gone } \\
2,4,9\end{array}$ & $4, \overline{6}, 9$ & $\overline{6,9}$ & $4, \overline{6}-9$ & $\overline{6-9}$ & $7-9$ & $\overrightarrow{9, S}$ & $\overline{\mathrm{I}, 9}$ & $1,2,9$ & $1, \overline{3}, 9$ & Gone & 二 & 二 & Z & 二 & - \\
\hline 46.0 & $\begin{array}{l}18 \\
18\end{array}$ & 5,9 & 6,9 & $6,7,9$ & 6-9 & 7-9 & 8,9 & $9, \mathrm{~S}$ & $9, \mathrm{~S}$ & קובנים & $2,5,9$ & $4,6,9$ & 6,9 & 6,9 & 6-9 & $7-9$ & $9, \mathrm{~S}$ & Gone & - & 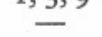 & - & - & - & $=$ & $=$ & 二 \\
\hline 48.0 & II & 5,9 & 6,9 & $6,7,9$ & $7-9$ & $7-9$ & 8,9 & $9, \mathrm{~S}$ & $9, \mathrm{~S}$ & $3,4,9$ & $2,5,9$ & Gone & & & & & & & - & - & - & 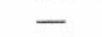 & 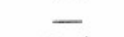 & & & \\
\hline 19.5 & 4 & & - & - & & - & - & - & - & & $S$ & $\mathrm{~S}$ & S & S & S & $\mathrm{S}$ & S & I & I, 2 & I, 4 & 2,5 & I, 5 & 3,6 & 6,8 & $6-8$ & $6-9$ \\
\hline 19.5 & 4 & - & - & - & - & - & - & - & - & S & S & S & S & $\mathrm{S}$ & S & S & $\mathrm{S}$ & I & 2,4 & I, 4 & I, 5 & 3,5 & 6 & $6-8$ & 7,8 & 8,9 \\
\hline 250 & 6 & - & - & - & - & - & - & - & - & $\stackrel{S}{S}$ & S & $\mathrm{S}$ & $\mathrm{s}$ & I(I tip) & $\frac{-}{0}$ & 6 & $9, \mathrm{~S}$ & I, 9 & I, 9 & $\mathrm{I}-5,9$ & Gone & - & - & - & - & - \\
\hline 26.5 & 7 & - & - & - & - & - & - & - & - & I (few) & 2,3 & 4 & 4,6 & 5,6 & 8 & 8 & $9, \mathrm{~S}$ & I, 9 & $I-3,9$ & Gone & - & - & - & - & - & - \\
\hline $28 \cdot 0$ & 9 & - & - & - & - & - & - & - & - & $s$ & 1,3 & 4,6 & 4,6 & 5,6 & 6 & 7 & $9, \mathrm{~S}$ & $1,2,9$ & - & - & $3,4,9$ & $4,5,9$ & 6,9 & 6-9 & 7-9 & $7-9$ \\
\hline 33.5 & II & $\overline{-}$ & $\overline{-}$ & $\bar{z}$ & $\bar{z}$ & 二 & $=$ & $=$ & 二 & $\begin{array}{c}\mathrm{S} \\
\mathrm{S} 2\end{array}$ & $\begin{array}{c}\mathrm{I} \\
\mathrm{I}, 3\end{array}$ & 2,3 & $=$ & $\begin{array}{r}4,6 \\
4,6\end{array}$ & 5,6 & $6^{7}$ & $9, S$ & 1,9 & 2,9 & $1,3,9$ & $3,4,9$ & $\begin{array}{r}1,4,9 \\
\end{array}$ & $3,6,9$ & $\begin{array}{l}6-9 \\
6-0\end{array}$ & $\begin{array}{l}\text { Gone } \\
6-0\end{array}$ & Gone \\
\hline $\begin{array}{l}34.5 \\
37.0\end{array}$ & $\begin{array}{r}8 \\
14\end{array}$ & 三 & 二 & 三 & 二 & 二 & 二 & 二 & 二 & $\begin{array}{l}1,2 \\
I \text { (few) }\end{array}$ & $\begin{array}{c}1,3 \\
2,3,4\end{array}$ & $\begin{array}{l}2,5 \\
2-5\end{array}$ & $\overline{4,6}$ & $\begin{array}{l}4,6 \\
5,6\end{array}$ & $\begin{array}{l}6 \\
6\end{array}$ & $\begin{array}{l}6,7 \\
6-8\end{array}$ & $\begin{array}{l}8,9 \\
8,9\end{array}$ & $\begin{array}{l}\text { I, } 9 \\
\text { I, }\end{array}$ & $\begin{array}{l}\text { I, } 9 \\
\text { I, }\end{array}$ & $\begin{array}{l}1,3,9 \\
1-4,9\end{array}$ & $\begin{array}{l}2,4,9 \\
2,4,9\end{array}$ & $\begin{array}{l}1,5,9 \\
\mathrm{I}, 5,9\end{array}$ & $\begin{array}{l}4,6,9 \\
4,6,9\end{array}$ & $\begin{array}{c}0-9 \\
4-6,9\end{array}$ & $\begin{array}{l}0-9 \\
6-9\end{array}$ & $6 \rightarrow 9$ \\
\hline $\begin{array}{l}37.0 \\
38.0\end{array}$ & 13 & - & - & - & - & - & - & - & - & I, 3 & $\begin{array}{c}2,3,4 \\
2,4\end{array}$ & 3,6 & $\begin{array}{l}4,0 \\
4,6\end{array}$ & $\begin{array}{l}5,0 \\
4,6\end{array}$ & $\begin{array}{c}0 \\
3,4\end{array}$ & $\begin{array}{l}0-8 \\
6-8\end{array}$ & 9, S & $\begin{array}{l}1,9 \\
9, \mathrm{~S}\end{array}$ & $\begin{array}{l}1,9 \\
1,2,9\end{array}$ & $\begin{array}{r}4,2,9 \\
I, 29\end{array}$ & $\begin{array}{r}2,4,9 \\
\mathrm{I}\end{array}$ & $\begin{array}{l}3,5,9 \\
3\end{array}$ & $\begin{array}{l}4,0,9 \\
I, 5,9\end{array}$ & $4,6,9$ & $4,6,9$ & $6-9$ \\
\hline 38.5 & 6 & - & - & - & - & - & - & - & - & I (few) & I, 3 & 2,6 & 4,6 & $3,4,6$ & 6,7 & 8 & $1,2,9$ & $1,3,9$ & $1,4,9$ & $1,6,9$ & $1,6,9$ & $3,6,9$ & $6-9$ & $6-9$ & $7-9$ & $7-9$ \\
\hline $40^{\circ} 0$ & I4 & - & - & - & - & - & - & - & $=$ & $1,3,9$ & $\mathrm{I}-\mathbf{4}, 9$ & $3-6,9$ & 6,9 & $5,6,9$ & $5,6,9$ & $6 ; 9$ & $7-9$ & I, 9 & $\mathrm{I}, 2,9$ & I, 4, 9 & $2-5,9$ & $\mathrm{I}, 5,9$ & $3,6,9$ & $6-9$ & 6-9 & 7-9 \\
\hline $46 \cdot 0$ & I2 & - & - & - & 二 & - & - & - & - & I, 2 & $\overline{2}$ & 3, 6 & 4,6 & 5,6 & 4,6 & $6,7,8$ & 8,9 & $9, \mathrm{~S}$ & I, 3, 9 & Gone & & & & & & \\
\hline $477^{\circ}$ & 14 & $=$ & $\overline{-}$ & $=$ & $=$ & $\bar{z}$ & 二 & 二 & $=$ & $\begin{array}{l}\mathrm{I}, 2,9,9 \\
\text { I (few }\end{array}$ & I, 3,9 & $\begin{array}{r}3,5,9 \\
3,6\end{array}$ & $\begin{array}{r}3,4,6,9 \\
4,6\end{array}$ & $\begin{array}{r}3,4,6,9 \\
4,6\end{array}$ & $\begin{array}{l}4,6 \\
4,6\end{array}$ & 6,7 & $\begin{array}{l}7-9 \\
9, S\end{array}$ & I, 9 & $\begin{array}{l}\mathrm{I}, 9 \\
9, \mathrm{~S}\end{array}$ & $\begin{array}{l}\text { I, 3, } 9 \\
\text { Gone }\end{array}$ & $2, \underline{4}, 9$ & I, 5,9 & $4,6,9$ & 6-9 & $\stackrel{6-9}{-}$ & Gone \\
\hline $\begin{array}{l}49.5 \\
50.0\end{array}$ & $\begin{array}{l}\text { I5 } \\
\text { I5 }\end{array}$ & 二 & $=$ & 二 & 二 & $\overline{-}$ & $=$ & $\overline{-}$ & 二 & $\mathrm{I}, 2,9$ & $\begin{array}{r}1,3 \\
1,2,3,9\end{array}$ & $\begin{array}{l}1,6 \\
1,5,9\end{array}$ & $\begin{array}{l}4,6 \\
6,9\end{array}$ & $\begin{array}{c}4,6 \\
5,6,9\end{array}$ & $\begin{array}{r}4,0 \\
3,6,9\end{array}$ & 6,7 & , & $\begin{array}{l}9,3 \\
8,9\end{array}$ & $\begin{array}{l}9,3 \\
\mathrm{I}, 9\end{array}$ & $1,3,9$ & $\mathrm{I}, 4,9$ & $\mathrm{I}, 5,9$ & $4,5,6,9$ & $\overline{6-9}$ & $\overline{6-9}$ & $\overline{7-9}$ \\
\hline $59^{\circ} 0$ & 14 & - & - & - & - & - & - & - & - & I, 3,9 & - & $\begin{array}{l}1,5,9 \\
\end{array}$ & $4,6,9$ & $5,6,9$ & 6,9 & $6-9$ & 8,9 & I, 9 & $1,2,9$ & $\begin{array}{l}\mathrm{I}, 3,9 \\
\end{array}$ & $1,6,9$ & $\mathrm{I}, 6,9$ & $3,6,9$ & $4-9$ & $6-9$ & $9, \mathrm{~S}$ \\
\hline $590^{\circ}$ & $2 \mathrm{I}$ & - & - & - & - & - & - & - & - & $1,3,9$ & $2,4,9$ & $2,6,9$ & $4,6,9$ & $4,6,9$ & $4,6,9$ & 9, S & 9, S & 9, S & $9, \mathrm{~S}$ & I, 3,9 & 2,9 & 4,9 & $4,6,9$ & 7,9 & 8,9 & 8,9 \\
\hline & 19 & - & - & - & - & - & - & & - & I, 2, 9 & I, 5,9 & $1,6,9$ & $4,6,9$ & $5,6,9$ & 6,9 & $6-9$ & 7 & I, 9 & $1,2,9$ & $1,4,9$ & $1,6,9$ & $1,6,9$ & $3,6,9$ & 6,9 & Gone & - \\
\hline $66 \cdot 0$ & 23 & $=$ & 二 & - & 二 & - & $\overline{-}$ & $\overline{-}$ & - & $1,3,9$ & $2,3,9$ & $2,6,9$ & $4,6,9$ & $4,6,9$ & $4,6,9$ & $6-9$ & Gone & - & - & - & - & - & - & - & - & - \\
\hline $67 \cdot 0$ & 24 & 二 & - & - & - & - & - & - & - & $1,2,9$ & $I-4,9$ & $2,6,9$ & $4,6,9$ & $5,6,9$ & 6 & $6-9$ & Gone & - & - & - & - & - & - & - & - & - \\
\hline $69^{\circ} 0$ & 20 & 二 & $\overline{-}$ & - & - & - & 二 & - & $\overline{-}$ & $2,4,9$ & I, 5,9 & $2,6,9$ & $4,6,9$ & 5, & 6 & $7-9$ & I, 8,9 & $1,2,9$ & I, 4,9 & I, 5,9 & $2,6,9$ & $9, \mathrm{~S}$ & $9, \mathrm{~S}$ & $9, \mathrm{~S}$ & 9, S & $9, \mathrm{~S}$ \\
\hline $69 \cdot 0$ & 32 & $\overline{-}$ & $=$ & $=$ & - & 二 & $=$ & $\bar{\pi}$ & $=$ & $2,4,9$ & $2,6,9$ & $3,6,9$ & 6 , & 6 , & 3, & 6 & $6-9$ & $1,3,9$ & $I, 3,9$ & Gone & & $\pi$ & & & - & - \\
\hline $71 \cdot 0$ & $\begin{array}{l}21 \\
18\end{array}$ & 二 & $=$ & 二 & $\bar{z}$ & 二 & & 二 & 二 & I, 3, 9 & I, 5,9 & $2-6$ & 4 & 5 & 6,7 & $6-$ & Gone & - & - & - & - & - & - & 二 & - & 二 \\
\hline 7 & $\begin{array}{l}18 \\
22\end{array}$ & 二 & 二 & 二 & 二 & 三 & 二 & 二 & 二 & $\begin{array}{l}1,2,9 \\
\end{array}$ & $2,4,9$ & $3^{-6}$ & 4, & 4, & & 6 & Gone & - & - & - & - & $\overline{5}$ & $\overline{6}$ & $-\overline{-}$ & - & $\bar{z}$ \\
\hline 7 & I9 & - & 二 & 二 & 二 & $\overline{ }$ & - & $=$ & $\overline{-}$ & I, & I, 4,9 & I, 6, 9 & $4,6,9$ & $5,6,9$ & $6,8,9$ & $7^{-}$ & 8 , & I, 9 & $1,2,9$ & I, 4,9 & $2,5,9$ & $1,5,9$ & 3,6, & Gone & - & -5 \\
\hline 79 & & & 二 & 二 & 二 & - & - & - & 二 & I, & $2,5,9$ & $3,6,9$ & 6 , & $3,4,6,9$ & $2,3,6-9$ & 3,4 & 7 & I, 9 & $I, 2,9$ & $I, 5,9$ & $3,6,9$ & $\mathrm{I}, 6,9$ & 6,9 & $6,7,9$ & $\begin{array}{l}7-9 \\
6\end{array}$ & $9, \mathrm{~s}$ \\
\hline & & & - & 二 & 二 & & - & - & - & & I, 4,9 & $2,6,9$ & 4,6 & 4,6 & 6, & & 8 & 8, & $9, \mathrm{~S}$ & & $1,2,9$ & I, 4,9 & $3,5,9$ & 6,9 & $6-9$ & $7-9$ \\
\hline & 32 & & & 二 & 二 & & - & - & 二 & & $2-6,9$ & $2-$ & 4, & 5, & 4 & & 6 & 8, & I, & Gone & - & . & & $\pi$ & - & - \\
\hline & 3 & & - & - & - & 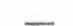 & - & - & - & $1,2,3,9$ & $2-4,9$ & 3,6 & $4, t$ & 5, & 6 & 6- & 8, & 8,9 & 9, & Gone & 二 & - & 二 & $\overline{-}$ & $\bar{z}$ & $\overline{-}$ \\
\hline $\begin{array}{r}95^{\circ} 0 \\
\text { I05.0 }\end{array}$ & $\begin{array}{l}37 \\
33\end{array}$ & - & - & - & - & - & - & - & - & $\begin{array}{l}1,3,9 \\
2,4,9\end{array}$ & $\begin{array}{l}2-4,9 \\
2,5,9\end{array}$ & $\begin{array}{r}4,6,9 \\
I, 6,9\end{array}$ & $\begin{array}{r}4,6,9 \\
4,6,9\end{array}$ & $\begin{array}{l}4,6,9 \\
4,6,9\end{array}$ & $\begin{array}{l}6,9 \\
6,7,9\end{array}$ & $\begin{array}{c}\text { Gone } \\
7-9\end{array}$ & $\overline{9, S}$ & $\overline{9, \mathrm{~S}}$ & $\overline{9, \mathrm{~S}}$ & $9, S$ & $9, \mathrm{~S}$ & $9, S$ & $9, S$ & $9, \mathrm{~S}$ & $9, \mathrm{~S}$ & $9, \mathrm{~S}$ \\
\hline
\end{tabular}

